\title{
Universiteit
}

Leiden

The Netherlands

\section{African historiography written by Africans, 1955-1973: The Nigerian case}

Kapteijns, L.

\section{Citation}

Kapteijns, L. (1977, April 1). African historiography written by Africans, 1955-1973: The Nigerian case. ASC Research Report. African Studies Centre, Leiden. Retrieved from https://hdl.handle.net/1887/484

Version: $\quad$ Not Applicable (or Unknown)

License:

Licence agreement concerning inclusion of doctoral thesis in the Institutional Repository of the University of Leiden

Downloaded from: https://hdl.handle.net/1887/484

Note: To cite this publication please use the final published version (if applicable). 


\section{AFRICAN HISTORIOGRAPHY WRITTEN BY AFRICANS, 1955-1973}

The Nigerian Case

Lidwien Kapteijns

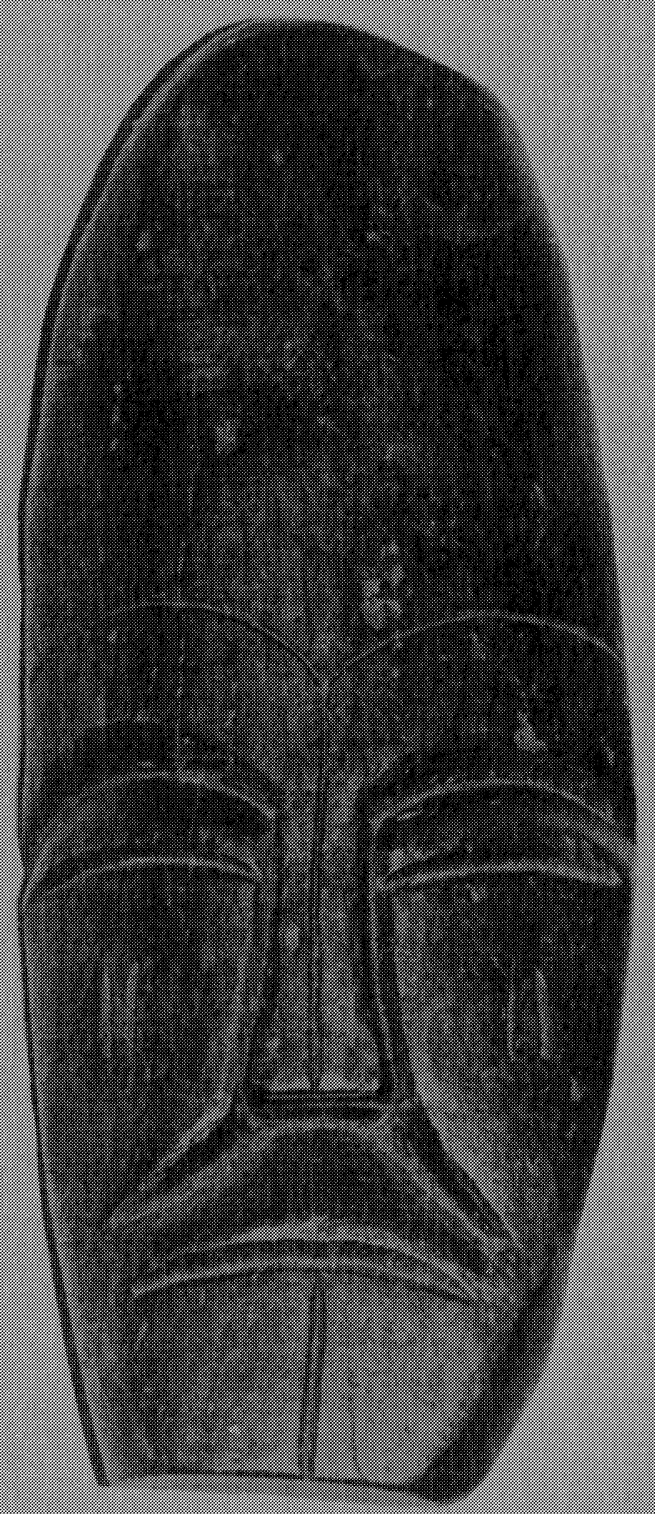

Leiden

Afrika-Studiecentrum

1977 
Copy right Lidwien Kapteijns 1977.

ISBN 9070110210

Thesis submitted at the University of Amsterdam in partial fulfillment of the requirements of the "doctoraal" degree in History, April 1977 .

Orders should be sent to: Afrika-Studiecentrum, Stationsplein 10, 2300 RA Leiden Price: Dfl. 7,50 (postage not included) 
To my parents. 
AFRICAN HISTORIOGRAPHY WRITTEN BY AFRICANS, 1955-1973.

The Nigerian Case.

Lidwien Kapteijns. 

CONTENTS

Introduction.

Part One: African Historiography 1850-1972/3

Chapter One: African Historiography prior to the 1950 s

A: African Historiography before the 1950s, written by Africans.

1. The Period 1850-1900....................... 7

2. The Colonial Period from 1900-1950 .............. 10

B: African Historiography prior to the 1950s, written by Europeans $\ldots \ldots \ldots \ldots \ldots \ldots \ldots \ldots \ldots \ldots \ldots \ldots \ldots$

Chaptex Two: The Institutionalisation and Africanisation of African History 1950/5-1960/5.

A: The Beginnings of Institutionalisation

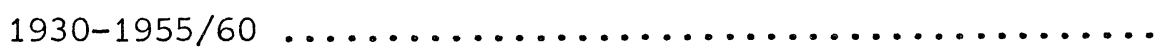

B: The Africanisation of African Studies

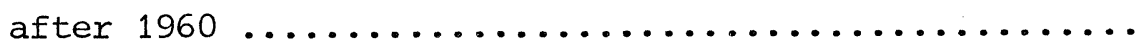

Chapter Three: The Manifestoes of the 1960s - History for

Self-Government

Chapter Four: The Manifestoes revisited: How African History should be written $\ldots \ldots \ldots \ldots \ldots \ldots \ldots \ldots \ldots \ldots \ldots \ldots \ldots \ldots \ldots \ldots$

Part Two: Nigerian Historiography 1955-1973

Chapter Five: Nigerian Academic Historians and the Late Pre-Colonial Past 1850-1900.

Introduction $\ldots \ldots \ldots \ldots \ldots \ldots \ldots \ldots \ldots \ldots \ldots \ldots \ldots \ldots \ldots \ldots$

Common Themes: African Reaction to

European Action:

1: Resistance to Imperial Control in:

a: Southern Nigeria..$\ldots \ldots \ldots \ldots \ldots \ldots \ldots \ldots \ldots$.

b: Northern Nigeria and the West African

Sudanic Belt ......................... 56

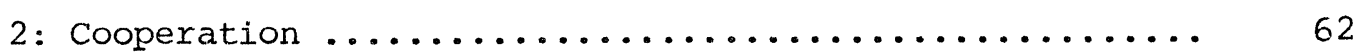


Chapter Six: Nigerian Historians and the Early

Pre-Colonial Past....................... 80

Chapter Seven: Nigerian Historians and the Colonial Past........992

A: Two early Nigerian Historians and the

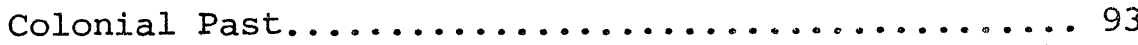

B: The New Administrative History................ 99

C: Other Nigerian Historical Studies dealing

with the Colonial Era.....................110

Chapter Eight: Nigerian Historiography on the Recent Past......117

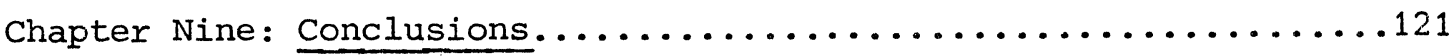

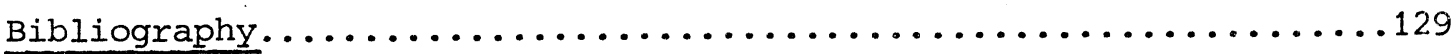

Figures and Maps: on page 9; between pp. 58 and 59; between pp. 77 and 78 . 


\begin{abstract}
"The real nature of history is to play
a part in history itself".
\end{abstract}

Paul Valéry ${ }^{1}$

\title{
'INTRODUCTION
}

Since the Second World War African Studies have grown from a cottage industry to a multi-national enterprise. This was how Lalage Bown put it in $1974^{2}$. She might have added that until the early sixties this cottage industry was completely run by foreigners, Africans forming only the raw material, that is to say, only coming in as the objects of more or less well-meaning European and American scholars.

This essay is an attempt towards a sketch of the development of one particular branch of this booming industry of African Studies, namely, of African historiography. It is no exaggeration to say that African history as an academic (sub-) discipline hardly existed before 1960, called the year of African independence. In the years after 1960, however, there was a real take-off in African historical. studies, as is evident from the mushrooming of Institutes of African studies and of professional historical periodicals, both in Africa and in the West. Also, for the first time in history, professionally trained historians of African origin came to the fore to contribute to the Renaissance of African history. One may well speak of the professionalisation and Africanisation of African historical studies.

It is obvious that the take-off of African historical studies in the early sixties can be understood only against the background of post-1945 developments, while its significance can only be valued correctly if compared to the embrionic state of African historiography during the colonial period.

Therefore the first two chapters of this essay (i.e. Part One) will sketch the development of the study of African history from its "unprofessional", tentative beginnings in the colonial period to the point at which it became a full-fledged academic discipline; from its pursuit by Western amateurs and scholars to the point at 
which Africans began to wield the pen as well.

Nevertheless this sketch is only an introduction to the essay's main theme which is historiographical: An analysis of the historical studies written by professional African historians from 1955 to 1972-3. Admittedly this time limit is rather arbitrary. Yet, it is dictated by the practical conditions of research in Holland where it is often very difficult to find out what books are published in Africa, let alone to get hold of them, and where the most recent volumes of African historical periodicals--indispensable sources for the 'historian of historical research'--are often not available. The fact that the essay is limited to professional historians of African origin can be justified, I feel, even without referring to time and space, by the fact that the essay is written mainly for Dutch fellow-students who may be familiar with some Western Africanists (such as Ph. Curtin and Basil Davidson), but only rarely with historians from Africa. In view of the Dutch reader also the section dealing with the sources available to the historian of Africa is more comprehensive than strictly required for the line of the argument.

The early sixties were a period of political and intellectual ferment in Africa. It was a time of aggressive, self-assertive manifestoes both in politics and in historiography. In their blueprints for African history African historians positively committed themselves to a historiography relevant to the newly independent nation and critical of the old 'colonialist' historiography of the past. The analysis of these manifestoes, these programmatical declarations of what African history should be and how it should be written, is the subject of the third and fourth chapter of this thesis.

Part Two (chapters 5 to 8) traces in detail what historical studies were actually produced in the fifteen years that followed independence in one particular west African country, Nigeria. In discussing the themes and trends of Nigerian historiography I have tried to relate the historical studies to the times and environment of the historians.

I have called this essay "an attempt towards, etc"; this is 
not because of false modesty or fear of criticism, but it should be noted that the author--when starting on this project--was new to the field of West African history. Moreover, the thesis has been a one-man venture from the beginning to the end. Finally, Africar historiography has been a rather neglected subject until now, although there are signs that it is coming in vogue. Nevertheless, ever if this survey cannot claim to be complete, I hope to have outlined the main trends and themes of Nigerian historiography.

A few practical points have to be made. Above I have accounted for the fact that the essay is limited to historians of African origin. There are other limitations: First, the survey is limited to the academically trained historians; that is to say, 'local' or 'spontaneous' African historians 3). --without formal academic training--are not included. Secondly, of the work of professional African historians general text-books, schoolbooks and works designed to popularise knowledge of the African past ${ }^{4)}$ are not included in the discussion. These limitations do not imply any negative judgement of value of either non-professional, or historical works of a general or popular nature. On the contrary, the achievement of African, and particularly of Nigerian historians in this field is impressive and would justify a special study of its own. Thirdly, a note on terminology must be made: Throughouth the essay I have used the term "African historian" for a historian of African origin who--as we will see below--usually wrote on African history. The term "Africanist historian" denotes any scholar pursuing the study of African history irrespective of his nationality. "African" in terms such as African history and African historians refers to what the British call "Africa South of the Sahara" and the French "l'Afrique Noire", that is to say, Africa without North and Southern Africa.

As for the selection of Nigerian historians discussed in Part Two of the essay, it has been arrived at by examining the following periodicals:

- African Notes; (Institute of Africa Studies, University of Ibadanl, $1(1963 / 4)$, no. 1---

- Bulletin de I'Institut Fondamental d'Afrique Noire/Bulletin IFAN, 
(from 1954: série B, Sciences Humaines) (until 1966: Bulletin de I'Institut Francais d'Afrique Noire), 1 (1939) - 4(1942); 8(1946)--

- Cahier d'Etudes Africaines/CEA, (VIe section, sciences économiques et sociales de l'Ecole Pratique des Hautes Etuảes), 1(1960), no. 1---

- Ghana Notes and Queries, (Bulletin of the Historical Society of Ghana), 1962, no. 4--- 1972, no. 12.

- Journal of African History/JAH, 1(1960), no. 1---

- Journal of the Historical Society of Nigeria:JHSN, 1(1956/59), no. 1 ---

- Kano Studies; (a journal of Saharan and Sudanic research) 1(1965/68), no. 1-4; N.S. 1(1973), no. 1 .

Now: annually published for Abdullahi Bayero College by oxford University Press, Nigeria.

- Notes Africaines, (bulletin trimestrielle de I'IFAN), 1949, no. 41-.-

- Ocu, (Journal of Yoruba and Related Studies), 1955, no. 1 - 1960, no. 8 .

- Odu, (Journal of West African Studies), 1(1964), no. 1 - 4(1968), no. 2; New Series: 1969, no. 1---

- Research Bulletin, (Centre of Arabic Documentation. Institute of African Studies, University of IbadanL, 1(1965), no. 2 \& 3; 2(1966), no. 1---

- Research Review, (Institute of African Studies; University of Ghana), 4(1967/68), no. 1---

- Sierra Leone Studies, (Journal of the Sierra Leone Society), New Series (1953), no. 1---

- Tarikh, 1(1965/67), no. 1---

- Transactions of the Historical Society of Ghana/THSG, 1(1952), no. 1---

In the Bibliography I have not only included works to which is referred in the text, but also all the books and articles of the Nigerian historians discussed which I have come across, and works of a more general nature, which have been of great use in the course of my research. 


\section{Notes Introduction:}

1. quoted by Gordon (1971), p. 2 .

2. quoted by Fyfe (1976), p. 2 .

3. the term 'spontaneous' historians is Eva Krapf Askari's, in the Preface to Akerejola (1970), p. iii.

4. Many African historians have invested much of their time and energy in writing general text-books and school books. This and their administrative duties as professors and chancellors of universities may account for the fact that some historians of the first academic generation have not produced any substantial monograph after their first work. This is illustrated by J.F.A.Ajayi whose major works after 1965--when his Ph. D thesis was published-- were: A Thousand Years of West African History-a Handbook, for Teachers and Students, Ibadan, revised edition 1969 (1965), edited by Ajayi himself in cooperation with I. Espie; and History of West Africa, 2 Volumes, London 1971-74, edited in cooperation with M. Crowder.

5. Copans (1971), pp. 440-1.

6. Buijtenhuijs (1975), pp. 541-6. 
research that is irrelevant to Africa, and for being mainly interested in the building of academic careers. Research on Africa should be both useful to Africa and 'committed' ('concerné') or revolutionary ${ }^{5)}$. It would lead me too far to go into the complicated question of what this 'new' anthropology, or history for that much, should be, and how it should be done6). I will touch on one of its implications only, namely, that Africa should not only be the object of Africanist studies, but also the public to which the results of the research ought to be presented. In my own essay I am mainly 'committed' to convince Dutch scholars and students of the importance and interests of the historical research done on Africa by African scholars. Nevertheless, I have thought it desirable to present it in English to allow Anglophone African historians--if not to profit from it--at least to criticise it.

Finally I would like to express my gratitude to the library staffs of the Koninklijk Instituut v/d Tropen in Amsterdam and the Afrika-Studiecentrum in Leiden and to acknowledge the help of $\mathrm{mr}$. Paul Doornbos, who encouraged and assisted me throughout my research. 
PART ONE

African Historiography: 1850-1972/3 

A. African Historiography before the 1950s, written by West Africans.

1. The Period $1850-1900$ :

The African historical tradition has been mainly oral and as such a source for the professional African historiography, which forms the subject of this essay. But apart from this "historio-oral" tradition, Africa has a historiographical tradition which is much richer than sometimes has been suggested.

In the second half of the nineteenth century there was a number of African historians--even if not 'professional' historians in the modern sense--who can be considered forerunners to modern African historiography, and as such deserve to be discussed in the context of this essay. Though far from constituting a 'school', they had many characteristics in common, even apart from the era in which they lived (i.e. the period preceding the Scramble for Africa and the establishment of colonial administrations in Africa):

They belonged to the new middle class which arose in the westernized trading communities of Liberia, Sierra Leone, Gold coast and the Bight of Benin (the present Southern Nigeria); and were the product of the educational activities of the christian missions, one could say, since most of them attended schools run by missionaries whose ideas they accepted and whose ideals they embraced. These missionaries, together with the advocates of 'legitimate trade' (in contrast to the trade in slaves) gave them encouragement and opportunities for rapid economic advancement.

All historians in question were whole-heartedly committed to the Western, Christian brand of 'civilisation', to a Christianised technologically developed modern social order; all of them actively demanded European support and tutelage. J.F.A. Ajayi characterised their ideals by quoting a Methodist minister of 1841:

"...that the Gospel of God may be preached unto her, that schools may be established, that Bibles may be sent, that the British flag may be hoisted, and that she (i.e. their country) may rank among the civilised nations of the earth". 1) 
The nineteenth century, approximately up to the 1870s, was a golden age for the incipient middle class. "The era of humanitarianism", as curtin called $i t^{2}$, was a period of limited missionary and commercial penetration, during which there was as yet no question of British annexation of direct administration. The "humanitarians" --convinced that Christianity, legitimate trade and "Civilisation" must go together-- aimed at creating a native agency, an African middle class, which would fulfill this civilising mission. As Ajayi put it: "it was a remarkable period of training in seif-government" 3 ). Yet, after the 1870 s the tide was turning. As is demonstrated by the increasingly racist results of the classification mania of biologists and anthropologists ${ }^{4)}$ European attitudes towards the Africans--until then characterised by a recognition of potential spiritual equality of the two races--changed rapidly. This change coincided with Britain's embarkment upon a policy of territorial annexation, and was reflected in church affairs as well: The policy of "native agency" which had reached its climax in the confirmation of S.A. Crowther as the first African bishop, was reversed. A new brand of missionaries entered upon the scene, called by crowther "the Anthropological Sort" 5). It was in this transitional period in which the image of Africa hardened into a very dismal and negative one, that Africans raised their voice in protest against these European racist assumptions. Here we are only concerned with those who were voicing their cultural nationalism through historical works:

- The French trained Senegalese Abbe Boilat, author of "Esquisses Sénégalaises" (1853),

- James Africanus Beale Horton, graduate in medicine from Edinburgh university and author of "West African Countries and Peoples" (1868), which bore the significant subtitle "Vindication of the Africar Race" and which attempted to disprove the pseudo-scientific aberrations of Europeen scholars,

- E.W. Blyden, originally from the Danish West Indies, but a naturalised Liberian, was the first to defend the concept of "the African Personality" 6) and the dignity of the negro race.

1 - Another pioneer of African history was the Gold Coast missionary C.C. Reindorf, whose "History of the Gcld Coast and Asante" (1889) covered three centuries and was based a.o. upon interviews with over two hundred individuals. 
One could mention many more: A.B.C. Sibthorpe, Otunba Payne, the Reverend Samuel Johnson, who wrote "The history of the Yoruba" (published in 1921, but written much earlier), as he himself put it: for "a purely patriotic motive, that the history of our fatherland might not be lost in oblivion..." 7).

All asserted African values in the face of increasing European intervention in Africa.

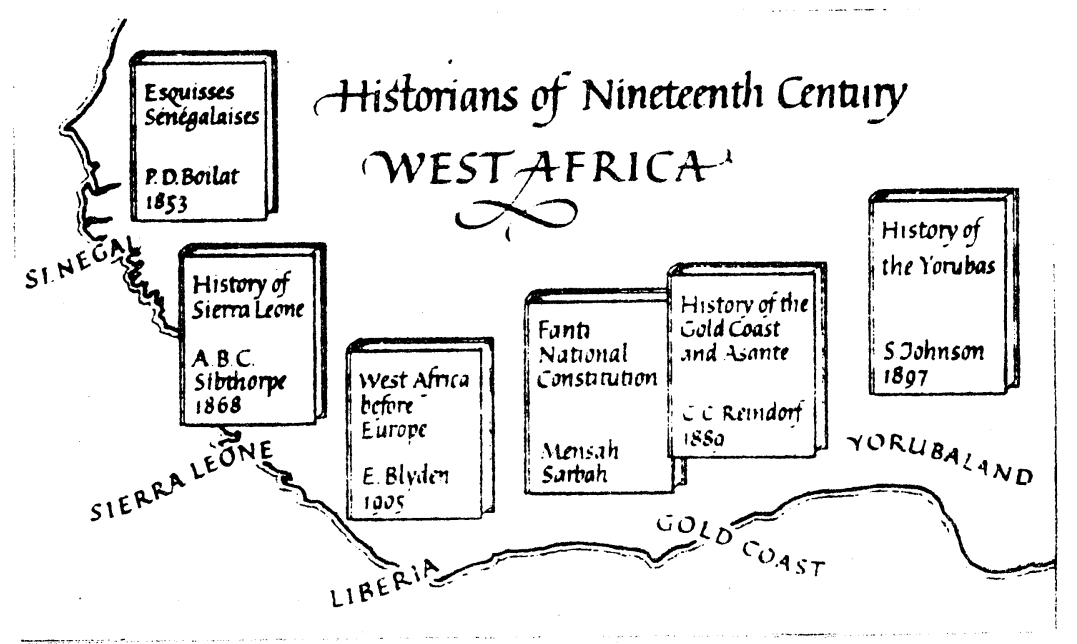

from July, (1968), p. 22.

The details of their historical works cannot detain us here. In the framework of this essay the only thing that matters is the extent to which they can be regarded as the forerunners to the modern African historians, who are the real subject of this essay: One may say that these early African historians resembled their 'professional' colleagues of the late 1950s and early 1960s in their reliance on oral traditions as historical sources; in their African perspective; in their attempt to vindicate and rehabilitate the African, emphasizing his contributions to world civilisation and taking pride in a glorious past as the basis for a new future. According to Ajayi, who traced the roots of Nigerian nationalism to the new middle class to which these early historians belonged ${ }^{8}$, the precolonial and modern historians even had a common ideology: That of nationalism.

Nevertheless the differences between the two groups may be even more significant: 
Although in both cases protest and self-assertion resulted from disillusion with European actions and intentions, the eariy historians continued to look to Europe and Christianity for guidance, and to take the European brand of civilisation, Europe's philosophy and technology as their final goal. They did not protest against the increase of European activities as such: they did not object to assimilation, but to "not enough assimilation", to the British refusal to allow them to have British law, representative government and a constitutional transition to self rule. They fulminated against the policy of trusteeship which, on the basis of racist theories of African incapacity, aimed at developing the Africans "along their own lines" instead of towards "civilisation" as the West understood it. Addressing Britain as Reindorf did would be unthinkable for a modern African historian:

"Rule, supremely rule, Britannia rule Thy acquired colony on the Gold coast... Superstition will then flee away and Christianity will rule supreme." 9)

After the experience of two world wars, and as a result of the oppression and exploitation which Africa suffered in the name of civilisation, the modern African historians had a much more negative view of the West. Although they shared with their predecessors a concern with discrediting racism and with demythologising Africa's history and its image in the west, both in their rejection of Europe and in their self-assertion they were more absolute. Another difference is the nature of the commitment of both groups of historians. Whereas the modern historians were committed to a territorially defined state (Nigeria, Ghana, etc.) which they intended to serve by writing history, the patriotisn of their forerunners was more cultural than political ${ }^{10)}$; their frame of reference the Negro Race, the African continent, or a not cleariy deliminated part of West Africa.

2. The Colonial Period from 1900 to 1950 :

From 1900 to 1950 there were hardly any professional historical works written on Africa, not even by Europeans, let alone by Africans. 
Even work by non professional "amateur" historians, like the ones we discussed above, was scarce. Yet, the lack of published books should not deceive us. Even if Africans hardly ever found opportunities to publish their studies, many works of a historical nature were written in this period. Most of these "local" histories, however, have been discovered in the decade following independence when African Ph. D. students went into the field to collect local sources. Practically all professional historical studies published in the Ibadan History Series have one section devoted to the manuscripts of (or interviews with) "local" amateur historians, more often than not literate Africans associated with the colonial administration as teachers, catechists, secretaries to chiefs, etc. Of course one cannot lump together all 'local' histories, but in their reliance on oral evidence, in their geographically limited scope, their preoccupation with "events" and a detailed description of manners and customs of ethnic groups, they resembled both the work of their pre-1900 predecessors-- who were, however, more self assertive--and the works of the European ethnographer historians, their colleagues and bosses. As a relatively unknown and neglected body of historiographical work, these "local" histories of the colonial period deserve to be studied more closely; not only by historians interested in the particular area or ethnic group already described by individual local historians, but also by those historians who devote themselves to writing the history of historiography.

It would lead us too far to analyse in detail the developments set in motion by the First World War. The sense of crisis in the West, the end of the belief in progress in wide circles, the waning of Eurocentrism, and "the rising tide of colour" have been discussed by others ${ }^{11)}$ and cannot detain us there. There is one specific movement of philosophy, however, which deserves at least to be mentioned in this survey. This is Negritude, which originated among black Francophone intellectuals in the thirties. Although specialists distinguish more than one Négritude ${ }^{12}$ ), for our purpose the definition formulated by Alioune Diop--founder of the periodical "Presence Africaine"--will do: 

"Négritude n'est autre que le génie nojir et en mêne temps
la volonté d'en révéler la dignité" lof.

Though at the time of its origin Négritude did not give rise to specifically historical studies, its vinaication of the value, uniqueness and superiority of African culture, and the rediscovery of traditional African values to which it gave rise, were amorg the main drives behind the upsurge of African historiography after the Second World War, influencing its tone and contents for a long time to come ${ }^{14 l}$.

Négritude was historically minded from the very beginning, since it was history which could rehabilitate Africa in the face of the Western world; and since it was a retreat into history, "a pilgrimage to the ancestral sources", as Senghor put it, that would reveal the true essence of Négritude, which was, in Sartre's terminology "the being in the world of the negro" ${ }^{15}$ ).

Négritude was a typical product of the Parisian intellectual climate of the 1930s, in which the dominant themes were "anti-themes", such as anti-politics, anti-rationalism, anti-mechanization, antimaterialism, anti-capitalism, anti-bourgeoisie, anti-individualism, and... anti-Americanism ${ }^{16)}$. This general climate was conducive to the development of Négritude: The critique of mechanisation and rationalism formulated by the surrealists fed into the glorification of Negro intuitive reason and emotion by Africans and West Indians. The increasing appeal of Marxism, cultural pessimism and self critism among many western intellectuals supported its refutation of Western values and Western domination. of formative influence also were the Pan African movement, and even more 17) the American Negro Renaissance or Nevi Negro Movement as represented by Negro authors such as Claude Mackay, Langston Hughes and Countee Cullen. Western scholars contributed to the development of Négritude as well. Ethnologists such as Frobenius, Lévy-Bruhl and Delafosse--in spite of all criticism that has been rightly levelled against them--not only assisted in destroying the old Eurocentric habits of mind, out also procured the evidence for the existence of a Negro culture.

Finally, the political events of the period, such as Italy's occupation of Ethiopia, the persecution of Jews in Germany, Ghandi's 
nationalism and the developments in North Africa were as many factors shocking the Negro intellectuals into an aggressive assertion of "the African Personality".

In what way was Négritude related to the African nationalism of the 1960s, which nurtured the professional African historiography under study here?

Wauthier 18) defined Négritude as "the expression in literature and the human sciences (particularly ethnology and historyl of African nationalism". Yet, if Négritude is African nationalism, it is the nationalism of a very specific group, characterised by Sartre as "well intended young men of the middle class who drew their inspiration from their phychological contradictions" 19), in other words, the Gallicised African and West Indian elite, culturally alienated from their African background and often embittered by the fact that complete assimilation was out of reach. Again, if Négritude is African nationalism, it is nationalism in a very specific phase of its development, namely, a stage characterised by a search for identity and authenticity 20), and by an emphasis on the spiritual and cultural, in contrast to the political and economic characteristic of later stages of African nationalism (Fanon, Mphahlele). Finally, if Négritude is African nationalism, it is nationalism with a very specific frame or reference; for it referred to the whole black race and the culture of a whole continent.

Yet, as the return to the ancestral sources, a search for identity and authenticity, a falling back upon history to rehabilitate the African and to vindicate Africa's greatness, Négritude foreshadowed and influenced the "manifestoes" of the professional African historians of the early sixties to be discussed below. It even provided these historians with a forum in the form of the mainly literary journal "Présence Africaine", founded in 1947.

B. African Historiography prior to the 1950s, written by Europeans.

The fulminations against European neglect and distortion of African history during the colonial period by African historians 
of the decade following independence justify the conclusion of a short characterisation of this "colonialist" historiography. That African history was a neglected subject during the colonial period is undeniable. Not until late did Afxican Studies come out of the "recoins d'un amateurisme aimable" 21). Throughout the colonial period there was hardly any professional historian who wrote on Africa - $-R$. Coupland, who wrote an East African history being the proverbial exception confirming the rule. Even if one would regard--for a moment--imperial history as African history, lamentably little was written on Africa 22). Africa was "the preserve of the anthropologist" (Dike 23), for--allegedly lacking written sources--it could not be part of the Humanities, which did include to some extent North Africa, Ancient Egypt and Ethiopia 24). Nevertheless, even if professional historiography did not concern itself with Africa, European knowledge of Africa increased enormously in the period following conquest and effective occupation. Much of what was written on Africa stemmed from the need to meet the practical problems of the administering power or the missions. Hence the predominance of administrators, military men, doctors and missionaries in the field. No wonder then that historical information on Africa was merely a spin off of administrative reports, evangelisation schemes and linguistic studies. Africa was indeed regarded as "the preserve of the anthropologist", but even here the amateurs, the administrator-anthropologists, dominated the field. To the modern historian of Africa their writings have nevertheless proved to be of great value--in spite of their obvious bias--in particular, since they were basically eye-witness accounts or recorded oral traditions. Unfortunately the material is not only of uneven quality, but also restricted to certain specific areas. It is not unlikely, however, that interesting work will still turn up, if not from the metropolitan archives--which have been thoroughly combed by countless European and African Ph.D. students--then perhaps from the archives of the former colonial capitals or from local (district--and divisional) archives. After the "official" and anthropological nature of European writings on Africa's past have been duly reported, much remains to be said. Research on Africa was not static, and there was a steady progress 
both in the number and quality of the studies produced. While the interest in Africa before the First World War was almost nil, the Inter war period heralded a new era. Partly this was the result of the changing needs of the colonial administrations. British indirect rule, for instance, with its implication of "finding the chief", necessitated a more detailed knowledge of the subject people. Partly also, it resulted from doubts about the viability of a Eurocentric worldview and the future of European domination in the face of "the rising tide of colour".

This increasing interest in Africa led to a coordination and sponsoring of African Studies. In 1926 the International Africa Institute was founded in London. It became a centre of ethnological, sociological and linguistic research on Africa, and soon began to publish the journal "Africa". This brings us to the question of the institutionalisation of African Studies--and African history as one of its branches--which received its decisive impulse only after the second World War.

This will be the subject of our next chapter. 
Notes Chapter One:

1. Ajayi (1961), p. 200.

2. Curtin, p. vi.

3. Ajayi (1965), p. 203.

4. For a discussion of the reason for this turning of the tide, see Curtin, (1964), p. 473.

5. Ajayi (1965), p. 263.

6. Esedebe (1970), p. 124; July (1967), p. 219.

7. July (1967), p. 272

8. Ajayi, (1961).

9. July (1967), p. 262.

10. This is denied by both Ajayi (1961) and Ayandele (1966) who emphasized the political dimension of their nationalism. Their argumentation is not completely convincing, I feel. See below, Chapter 5.2

11. Albertini (1966), p. 23.

12. Hymans (1971), p. 23.

13. Quoted by Kesteloot (1963), p. 263.

14. See e.g. the work of Francophone historians such as Cheikh Anta Diop, I. Kake and Th. Obenga writing a.o. in Présence Africaine.

15. Sartre quoted by Hymans (1971), p. 22.

16. Hymans (1971), p. 31.

17. Senghor (1971), p. 8 .

18. Wauthier (1966), p. 278.

19. Quoted by Hymans (1971), p. 128.

20. von Albertini (1966); see von Abertini's second phase, p. 31.

21. Cornevin (1960), p. 50.

22. Herskovitz (1964), p. 33.

23. Dike (1964), p. 31 .

24. Herskovitz (1964), p. 31. As late as 1969--at the XXVth Orientalist Congress held in Moscow-Africanist scholars came to consider their presence at the conference and the status of African Studies as an adjunct to orientalist Studies, as a 'survival'. 
CHAPTER TWO

The Institutionalisation and Africanisation of African

Historiography, 1950-5 - 1960-5

The institutionalisation of African history--or African Studies of which history is an integral part--was a condition sine qua non for its professionalisation. The most distinctive feature of the process was that it was monopolised by Europeans until the 1950s, and dominated by them at least until the coming of independence in the early sixties. Two phases can be distinguished: The first phase (1930 - 1955/60) witnessed the institutionalisation of African Studies both in Europe, and Africa. The second phase (1955/60 - 1965) saw further institutionalisation, but--more important-- the Africanisation of subject, research personnel and institutions of African history as well.

A. The Beginnings of Institutionalisation, 1930-1955/60.

We will take up the thread of the argument where we left it at the end of the preceding chapter, that is to say in 1927, when the International Africa Institute was established in London. The next important development was the establishment in Dakar of the Institut Francais de l'Afrique Noire (IFAN) in 1937. Under the direction of Th. Monod (1938-1964) it began to publish--apart from the house magazine Notes Africaines--the Bulletin de l'IFAN, which is today one of the leading journals in the field of African Studies in Francophone Africa.

The developments during the Inter War period were only a prelude to those of the period after 1945, which saw a proliferation of institutes and centres of African Studies, of African (professionall journals and international-or rather intercolonial--conferences. The "First International Conference of Africanists of the West"--one wonders whether there were any other Africanists than those from the West--was held in 1945 in Dakar. It opened a whole series of conferences, the second and third taking place in resp. Bissau (1947). 
and Nigeria (1949). In the years 1947, 1952 and 1955 three conferences on African history were held in Nairobi, Algiers and Northern Rhodesia resp., while in 1953, 1957 and 1961 three truly epochmaking conferences, again on African History and Prehistory, and coupled to the names of R. Oliver and J.D. Fage, were held at the School of Oriental and African Studies in London. One could extend the list almost at will.

1. The institutionalisation of African Studies in Europe.

It was in this post-war period that African history as a branch of African Studies was incorporated in the curricula of European and American universities. In the U.S.A. North Western University included an inter-disciplinary African Studies programme in its curriculum in 1947. In Great Britain African Studies were initially best developed at the different institutes of the University of London. The School of Oriental and African Studies, the most important of these, published from 1960 onwards the Journal of African History whose importance for the impetus that African studies received. in the 1960 s was very well expressed by T.O. Ranger when he characterised the journal "as the combined manifesto, charter, programme and shop-window for the field" ${ }^{1)}$. In France there was tuition in African Studies from 1954 onwards at the Ecole Pratique des Hautes Etudes (E.P.H.E.), VIe section, a.O. by G. Balandier (from 1954/5), P. Mercier (1956/7) and H. Brunschwig (from 1961/2 onwards). In 1958 the 'Centre d'Etudes africaines' of the E.P.H.E. was founded, which published from 1960 onwards the journal Cahier d'Etudes Africaines, directed by Pierre Alexandre.

At the Sorbonne a 'Centre des Recherches africaines' was founded in 1962, with the creation of three "maitrises de conférence": G. Balandier for Sociology, R. Mauny for ancient and medieval African history, and H. Deschamps for contemporary African history 2).

2. The institutionalisation of African Studies in Africa prior to 1960 .

As for Africa, between 1945 and 1948 IFAN created local branches in all provinces of the Federation of French West Africa. Often these 
centres began as one-man or two-men enterprises ran by one French director and an African archivist. There were centrifans in the following provinces: Ivory Coast, Senegal, Soudan, Togo, Cameroon, Dahomey, Guinea, Mauritania and Niger, each local branch publishing its own periodical ${ }^{3}$ ).

The establishment and development of Higher Education in Africa after 1945 is not equivalent to the institutionalisation of African Studies, of course; for, while the students were African, the teachers, management and curriculum of the new secondary schools and universities were not. Nevertheless, African Higher Education was a conditio sine qua non for the Africanisation of African Studies and their further institutionalisation.

Only the most importment developments in British and French West Africa can be touched upon:

In French West Africa the year 1957/8 represented a mile-stone, for in this year the University of Dakar was established. IFAN; until then the centre of all 'pure' (in contrast to 'applied') research in all disciplines for the whole of French West Africa, was incorporated into the new university in 1959. Thus it became independent from the administration of the A.O.F. The local centres became independent of the 'mother' institution in Dakar, and came to ressort directly under the governments of what soon were to become independent states.

In British West Africa the most important development in this period was the establishment of several University Colleges, i.e. universities which as yet did not have the authority to award their own degrees, and did not set their own standards, curricula and examinations, but which were related to another, senior university, in this case the University of London. The following University Colleges were established in West Africa: the University College of Ibadan, Nigeria (1948), that of Legon, Gold Coast (1949), and that of Sierra Leone (1960). At the same time an increasing number of scholarships were awarded to West Africans to study in Europe and the U.S.A. 4) Although the British were relatively late in shifting the locus of African Studies to Africa, the level of African Studies in British West Africa was comparable to that of the IFAN and its independencies. The history programmes at these University 
Colleges included only a bare minimum of African History, it is true, but several historical societies were founded, which were composed of both amateur historians and professional (mainly European) historians. These Historical Societies-- a typically, though not exclusively British phenomenon, one might say-- also published their own historical journals ${ }^{5)}$.

Summarizing one can say, that by 1955 there were a number of centres of Africanist research in existence, both in and outside Africa. In Africa a university system had been set up--including History Departments-- which could be adapted to serve African studies, once the curriculum had been "africanised". African scholars who could--and would--undertake this Africanisation were being trained, both in Africa and abroad.

B. The Africanisation of African Studies after 1960.

As we have seen in the preceeding section, by 1955 African Studies had been institutionalised both in the West and in Africa. Yet, whereas in Europe and the U.S.A. tuition in African Studies had just begun, in Africa it was practically non-existent. Things were moving fast, however, with the coming of independence: It was not only a matter of africanising teaching personnel; the university colleges had been patterned on British universities, and the obsession with standards from the side of British and Africans had guaranteed an African university which could hardly be distinguished from its European 'mother' university; even so much that, "Indeed until a few years ago, and possibly even today (i.e. a university in West Africa was studying Stubb's Charters in Latin (when Cambridge undergraduates were deemed incapable of such a mental, effort) and the practice may have survived independence."

Whether this is an exaggeration or not, it is undeniable that the africanisation of the curriculum and the institutionalisation of African history have had to await idependence, the time when the university colleges obtained full university status.

Then African history received an enormous impetus, since it became the major concern of History Departments and multi-disciplinary Institutes of African Studies which mushroomed at many of the existing and new universities. 
To restrict ourselves to Nigeria: In July 1963 the University of Ibadan set up an I.A.S. (Institute of African Studies), which began to publish its own journal called African Notes. It also published. the Archaeological Newsletter, the Journal of West African Languages, and from 1964, the Research Bulletin of the Center of Arabic Documentation. Soon four other universities were established: the University of Nigeria, Nsukka (1960), the Ahmadu Bello University, Zaria, the University of Ife, Ile-Ife and the University of Lagos (all three of them in 1962), two of them having special Institutes of African Studies.

This was only the beginning of a spectacular development. At present (1977) Nigeria counts no less than ten universities and three university colleges.

By 1965 African history had really been institutionalised, professionalised and africanised, for research into the African past was kept up continuously, by a body of professional academic historians (and other African scholars) working within the framework of an institution created for that purpose, in Africa itself. As far as former French West Africa is concerned, here the institutionalisation and africanisation apparently did not reach the same level as in the Anglophone areas-with the exception of the University of Dakar and the Institut Fondamentale pour l'Afrique Noire (as the post-independence IFAN has been called). This initial lag of Francophone Africa is still perceptible, I believe, in the relatively small number of professional historians of Francophone West African origin.

I must apologise to the reader for this bloodless account of institutes, history departments and professional journals. Yet, before turning to the historians peopling these buildings and magazines, I have considered it indispensable to sketch the surroundings in which they operated and functioned. The enormous proportions the study of African history has assumed since 1960, and its uneven development in different parts of West Africa are incomprenensible without taking into account the international developments of the period leading up to independence. 


\section{Notes to Chapter Two:}

1. Fanger (1976), p. 17.

2. R. Mauny (1964), pp. 271-3.

3. see Hess (1964), Cornevin (1960), pp. 47-9, Autra (1964), Cornevin (1963), "Historique de l'Institut Français d'Afrique Noire" (1961), R. Mauny (1962), Alagoa (1975), pp. 171-83, Francine Muel-Dreyfus (1972).

4. see e.g. for Nigerian students studying in Britain between 1944-1954 Appendix VII in Fafunwa (1971).

5. The Historical Society of Ghana (HSG) began to publish its Transactions in the early fifties, together with the more 'domestic' Ghana Notes and Queries; the Journal of the Historical Society of Nigeria dated from 1955, while the Society of Sierra-Leone--not specifically historically oriented--published the Sierra Ieone Studies from 1953 onward.

6. Knowles (1962), p. 224. 
CHAPTER THREE

The Manifestoes of the 1960s:

History for Self-Government

African historians did not enter the international academic scene unobserved: They came with drums beating and colours flying. The manifestoes they presented to an international audience in the late fifties and early sixties were blueprints for African history as they thought it should be written. All manifestoes dealt with the why and how of African historiography, and with the role and responsibility of the African historian.

The early manifestoes of the late fifties and early sixties were remarkable for their apologetic and at the same time aggressive tone. This feature became less obvious in later manifestoes, and was completely stood upon its head in an article written by $W$. Ochieng ${ }^{1)}$ in 1974, as we will see below. However, the change of tone is less significant than the changes in the concept of what truly authentic African historiography should be. For, even though the questions of "Why African history" and "How should it be written" remained the same throughout the period under study, the answers were constantly in flux.

In the answers African historians gave to the question of "Why African history?" two aspects can be distinguished, one negative, and the other positive. First, the answers were 'negative' as far as they were a reaction to, and a denial of the validity of the prevailing climate of opinion in the west during the colonial period (and after); and as far as they tried to restore the balance by rehabilitating African history. Secondly, the answers were 'positive' in the sense that they were defining a clear and new function for African historical writing, outlining a programme for making the past usable and relevant to modern Africans.

The 'negative' aspect of the programme of the African historians was essentially the 'demythologisation' of African history. The African had to be liberated from the colonial experience, and therefore African history which until then had been a history "sans nous et contre nous" 2) had to be rewritten. As Biobaku put it: 
"Les responsabilités de l'historien africain consistent à être fidèle à son métier et par là à le plier à la tâche vitale de libérer le passé africain gajs préjugés qui se sont accumulés à travexs les âges".

Which European myths were the African historians trying to destroy?

The most important one--recurring time and again at the be-ginning of the manifestoes--was the myth that Africa had no history. It became an almost classical stylistic device to begin a manifesto by quoting Trevor-Roper, Hegel, or some more or less obscure 'colo-. nialist' administrator, stating that Africans had no history. This would be followed by a cynical remark which would bring all but the truly racist readers on the author's side for the remaining part of the plea. From hindsight one is tempted to consider this tactique as flogging a dead horse, but one should keep in mind that at that time scepticism about African history--its feasibility and its significance--was still wide--spread in large--including academic--circles.

What did Europeans mean when they said that Africa had no history? They had several things in mind: Firstly, they were of the opinjon that Africa had no history of its own since it had always been static and passive. Africa had, allegedly, always been a tabula rasa on which only outside invaders had left some traces. It was no more than "the space in which Europe swelled up" 4). Secondly, Africa allegedly had no history that could be traced and written down, since Africa had no script, and hence no written sources. Finally, it was said, there was no African historical consciousness ${ }^{5)}$.

Destroying these myths in order to rehabilitate African history and Africans in the eyes of the West was the African historian's first task. However, even more important was the rehabilitation of the African and African history in the eyes of the African themselves: "Colonisation is chaos", said Césaire, for it separates and divides both in space and in time; hence the artist--and the historian for that much-- has to restore "the double continuity that has been broken by colonialism: continuity with the world and with ourselves" History was called upon to restore this continuity that had been broken by the colonial experience. The obsession with continuity was one of the most significant features of the African historiography 
of this early period. This was evident in the work of the senegalese historian Chejkh Anta Diop, who contended that west African culture and languages could be traced directly to the ancient Egyptians, but it also featured in less controversial historical studies, as we will see below.

on the one hand this obsession with continuity led to a playing down of the importance of the colonial period ${ }^{7)}$, and hence to its neglect in the historiography of this period. On the other hand, the desire to restore the continuity gave rise to "une recherche fascinée des sources" 8).

For the westernised African intellectual--swerving between emulation and resentment of the West, between a desire for authenticity and effectivity and modernisation--it was a search for psychological balance and identity, for "dépouillé (...) de son histoire, il est étranger à luimême; on dira qu'il est aliéné et il l'est, en effet, dans tous les senses de ce terme". 9) Not only the westernised elite, but the whole continent was affected: for history, the collective memory of nations ${ }^{10)}$, was considered indispensable for an integrated and independently acting people or nation:

"un peuple sans histoire c'est un homme sans mpémoire. Le voyageur sans bagage dont parle Burloud..."

By restoring the broken continuity, history was to cure the alienation, and to trace the identity of the African Personality. As Dike put it:

"African Studies will be the means to the achievement for the African, of greater selfrespect, the means to the creation of a suref African Personality in the face of the modern world" 12 .

By revealing a glorious past history was called upon to demonstrate the "anciennité" of African culture, e.g. by pointing to its Egyptian origins, as Cheikh Anta Diop claimed. It could throw light upon the autonomy and originality of African civilisation, and vindicate African capacity for self-government, e.g. by pointing to the great West African medieval empires. Finally, by describing African resistance to the imposition of colonial rule, it could disprove African passivity

The function of history had to go beyond the temporary one of rehabilitation and of setting the African record straight. History 
ought to achieve more than bolstering up the African Personality and restoring the African's equilibrium. History had to make a positive contribution to the unification of Africa, and to a strong and independent nation-state as well.

What exactly was expected from the historian?

In terms of a Pan African context his task was described in this way:

"il ne faut pas étudier le passé pour s $\mathrm{s}^{\mathrm{y}}$ complaire, mais pour servir les tâches présentes de la renaissance africaine, en particuliers) pour aiguisex la conscience de l'originalite et do l'unité"

With regard to the nation-state history had to fulfill a crucial function as well: In Africa nations did not grow organically as in Europe, but were built. National independence did not result from and follow a consciousness of national identity and unity, but actually preceded it. In the absence of a common language, religion, and sometimes even "race" --and in any case ethnic group-- the new nations were calling upon history and the historian to define a national identity, and to create and mould a national consciousness. As Dike put it:

"I am convinced that history and culture are factors as important in the construction of a nation as more material considerations, for a nation withgut a distinctive history and culture is without content".

How precisely was history expected to contribute to "nation-building"?

First of all it could do so by linking the new leaders to great and glorious ancestors, in order to give them some legitimacy in the eyes of the people ${ }^{15)}$. Secondly, by linking the new states to the great medieval empires (Ghana, Mali, Songhay), history could demorstrate the permanence of the nation--implying that current problems were only temporary. Past greatness was to be the quarantee of future greatness, and at the same time a stimulus and a source of inspiration for undertaking energetically the task of national reconstruction. History was to be "une action de salut public" 16), and the basis of civic education ${ }^{17}$ ).

"L'Afrique a besoin de se souvernir pour agir", said the Guinean historian I. Kake:

C'est dans I'histoire nationale que 1 'on trouve les motifs pour agir, pour espérer, pour résister. Ainsi l'histoire est nécessairement pafjionale dès lors que la nation est une réalité vivante". 
"Si on n'a pas d'histoire, si on n'a pas de culture nationale, il sera donc difficile de prévoir avec sérénité l'avenir de nos pays" wrote the Congolese historian Tchikaya, and, stressing history's mobilizing function:

"En donnant conscience aux hommes africains de leur passé, et en consolidant aussi leur sentiment d'unité nationale, ou d'unité africaine, les historiens africains participent d'yne manière capitale à cette prise de conscience des peuples" 21 . The reader may have noted the confusion of the national and continental framework in the definition of history's mobilizing function. Apparently the existence of strong, stable and unified nationstates was not regarded as incompatible with African unity; the two were considered complementary. This point of view recurred time and again in the various manifestoes ${ }^{22}$ ). Apart from a gift for rhetorics and an optimistic view of the future on the part of the African historians, these manifestoes demonstrate the incorrectness of the view that the 'historians' commitment to Africa and that to the nation-state followed each other in time, with 1960 or independence as a watershed 231.

The reader may feel that African historians, in vindicating the relevance of their discipline, manifested a blind adoration for the nation-state and the national leaders. Yet most of them were not ready to make history a handmaiden to nationalism irrespective of academic standards and requirements of objectivity. The Nigerian historian Biobaku professed his concern with academic standards more than once, but did not regard it as incompatible with his commitment to the 'demythologisation' of African history:

"...les responsabilités de 1 'historien africain consistent à être fidèle à son métier et, par là à le plier à la tâche vitale de libérer le passé africain des préjugés qui se sont accumulés à travers les âges (...) l'historien ne doit jamais se proposer de se prêter à la politique du moment, mais il n'a guère besoin de s'excuser si le passé africain se révèle en définition plus glorieux qu'on ne se le figure généralement à tort. (...) ...il encombe à l'historien d'assurer que l'image qui s'en dégage ne soit plus déformée à travers les miroirs d'un nationalism irréfléchi"

Maybe Biobaku was unique in his explicit reference to the dangers of an ideological "nationalist" historiography of Africa. Yet, even he shared the optimism expressed at the Fourth International Seminar held in Dakar in 1961, that: 
"...history in Africa, without ceasing to be objective, can serve the national conscience in seeking to make the past, with its 25 plendours but also with its miseries, more widely known".

Below we will see to what kind, and what quality of historical work these manifestoes actually gave rise--at least in Nigeria. Here we are only concerned "with the manifestoes themselves--the declarations of principles, the credos of African historians--and with the changing concept of the relevance and methodology of African history herein expressed. Even if the first African historians identified themselves and their work with the new nation and the status quo, this identification was only temporary. Disillusion with extreme and uncritical nationalism, and the form which independence took, appears to have set in fairly soon. No one expressed this "end of ideology" more explicitly than the Nigerian novelist Wole Soyinka, writing just before the Nigerian Civil War (1967). Looking back upon the way in which the writers-- and the same holds true for the historians--had attempted to transform themselves into a small part of the machine of national reconstruction by undertaking to reveal the greatness of African culture and history, he lamented their mistake of entrusting the politicians with the running of the country:

"The African writer needs an urgent release from the past. of course the past exists... the past exists now, at this moment it is coexistent in present awareness. It clarifies the present and explains the fufure, but it is not a fleshpot for escapist indulgence..."

Disillusion and a more critical and pessimistic view of the present--even if not necessarily of the future--crept into the camp of African historians as well, sowing discord among their ranks: On the one hand there were those who stuck to their belief in nationalism and to their view of national movements as "real and successful struggles for independence from the colonialists, in which mass participation was at all points crucial" 27). On the other hand there were "the radical pessimists", for whom "national independence was an episode in a comedy in which the colonial powers handed over to their selected and groomed bourgeois successors, and in which notring fundamental was changed". 28)

The lack of more explicit public abjurations of faith is not surprising and does not necessarily point at inveterate conservatism as an inherent feature of the historian's mentality. African historians 
had to tread softly on the dreams and slogans of the national party politicians, whose favour they had to court in order to have their research schemes financed 29 ).

Gauging the atmosphere of some Seminars and "Tables Rondes"--as Hopkins did 30) --one perceives only slight symptoms of change, initially; for example, when the Congolese historian Tchikaya casualIy remarked that national history, while contributing positively to suppressing regionalism and tribalism, actually served a certain class in power. ${ }^{31)}$ Instead of looking for more public motions of no-confidence, we will turn to the changing concept of what African historiography should be, as expressed in the credos of the seventies, when the "negative" rehabilitating phase of African historiography had been largely left behind.

If one examines recent papers by K.O. Dike (1973) and Ajayi \& Alagoa (1974), one perceives that the mixture of apology and aggression which characterised the early manifestoes has largely disappeared, even if some of the--by then--stereotyped phrases are still present. "Today polemics is rapidly yielding place to scholarship", Dike said 32 ).

Alagoa and Ajayi began rather traditionally by professing that history was

"to correct the distortions and to bridge the gap created by the colonial experience in the African historical tradition"... "to provide a sense of continuity, and to explain to each peşson and each people where they fit into the scheme of things". to explore "the continuity of African history especially of black Africans to their present predicament".

Yet, what followed was actually a disavowal of political history with the aims of legitimation and rehabilitation:

"Although it (i.e. the political history of the pre-independence period) enabled the African politicjan to hold up his head vis a vis the rest of the world, it did not equip him with the understanding and sȩpse of values necessary for reshaping his own society".

In other words, political history, which had proved to be inadequate to the task of rehabilitation and demystification, was unable to prepare a 'good' decolonisation, and to provide guidance to a government involved in "national reconstruction". On the basis of their conclusion that:

"...it is in an emphasis on social and economic history that African historiography can show the relationship between the concerns $3 f$ historians and the preoccupations of modern African states" 36 ) 
one may suggest that in their opinion it was social and economic history that had to provide the national governments with this understanding and sense of values necessary for reshaping their society", which they had mentioned before.

Whereas the credo of these two Nigerian historians stili required an effort in close-reading to disentangle the new insigkts that had come to join the stereotypes, the Kenyan historian William M. Ochieng dissociated himself very emphatically and explicitly from the African historiography of the early sixties. His muckraking article in the Kenyan Historical Review of 1974 was in many ways the opposite of the manifestoes of the sixties. ochieng followed the standard pattern by opening his argument by quoting Trevor-Roper's famous, or rather notorious statement that,

"...perhaps, in future, there will be some African history to teach. But at present there is none, or very little; there is only the history of Europeans in Africa. The rest is largely darkness, like the history of the pre-European, pre-Columbian America. And darkness is not a subject for history". 37)

Unlike his colleagues of the early sixties, Ochieng actually approved of Trevor-Roper's candour, for which the latter had become "the butt of innumerable emotional insults by nationalist African his-torians, who see his standpoint as motivated by purely racial prejudice" 38). According to Ochieng it was these nationalist historians who deserved criticism:

"Building on the foundations which had been led by Vansina, Ogot, Davidson, Oliver and Fage the majority of African historians have largely demonstrated in thought, if not in fact, that Africa is a dynamic entity, with a glorious past, and a promising future". 39)

To Ochieng this was a romantic and heroic vision of the past, ignoring the central question of African historiography: "How can we account for Africa's age-long stagnation?" 40)

"...to answer this question we must bring to the discussion a freshness and a detachment of mind which far exceeds our racial attitudes and standards. For many of the ideas, concepts and models which have been so far employed for the analysis of our past are no longer pertinent, or useful: it will not, for example, be enough just to gloxify the African past by lifting shoulder-high a few of her glittering achievements like the Zimbabwe architecture, the primitive peasant empires of the Sudan and the Makonde sculptures. These, I will reluctantly grant, are surpising examples of achievement, but they are also at the same time mere flashes within a background of utter stagnation".41) 
Maybe it is true that by contending that "the emperor of African historiography had no clothes", Ochieng only meant "to shock by embracing the unthinkable", as T.O. Ranger has suggested 42). Yet, his complete reversal of the earlier manifestoes, his deprecation or accusation instead of rehabilitation of the African past is an indicator of the changes which have taken place in African historiography since the early sixties.

What kind of history did Ochieng advocate, one would like to know. First of all it should be a historiography which would account for Africa's stagnation; its "undercivilisation", i.e. its lag in social, economic and technical development in comparison with Europe, for instance; its poverty.

"Compared to the Western World Africa remained largely undercivilised until the arrival of the Europeans. This undercivilisation was not caused by geographical factors, by Nature, by the quality of African intelligence, or merely by expropriation of Africa's economic surpluses by Europe. It was a function of Africa's technological backwardness, the which backwardness came about because Africa had plenty of land. There was never, really, any pressure on land to force man to fall back on technology to earn a living by alternative means" 43).

It is not our concern to elaborate on the veracity or originality of this thesis. Here we are mainly interested in its consequences for Ochieng's concept of African historiography: a historiography which has an economic and agricultural focus; which is not apologetic or irrealistically selfindulgent; which does not try to smooth over Africa's problems and weaknesses, thus giving rise to a false optimism for the future, and a dangerous passitivity in face of the present; a historiography which faces reality and looks for explanations (and solutions?) in the socio-economic conditions of Africa's agricultural population. This was a long way indeed from the optimism of the early manifestoes, which looked upon (mainly political) history as a means to justify and glorify a new political order, and to mobilise the masses in support of it.

The same concern with a social and popular focus of African historiography as Ochieng advocates---though with less emphasis on economic factors--was expressed by other African historians in the late sixties and early seventies:

On the other side of the continent Ayandele denounced the imbalance of Nigerian historiography 44 ), in particular the neglect of the 
internal (precolonial) evolution of Afxican societies in favour of the study of African reaction to European action; and the preoccupation with the social elite instead of the common people. In Francophone Africa J. Ki- Zerbo from Upper Volta advocated a social history 'from below' as well:

"De plus en plus, l'histoire veut embrasser en largeur et en profondeur le fleuve d'évolution humaine. Elle ne s'intéresse. pas seulement à l'écume superficielle qui ne révèle rien du débit ni à fortiori du relief sous- jacent". 45)

African historiography should be "une histoire, faite par les peu-ples ...pour les peuples". 46)

In a comparable way the general meeting of African historians who are engaged in writing the general history of Africa, sponsored by UNESCO and announced for 1975, committed itself to a programme of writing "une analyse introspective du développement de l'Afrique par les Africains"; and of concentrating upon the evolution of society, rather than "events", upon the people not upon the kings 47). How did these manifestoes and declarations of principle work out in practice? This will be examined in the fifth chapter of this thesis, at least for one specific country, Nigeria. Before proceeding to this case- study of Nigerian historiography we will examine the second major question of the manifestoes: How should African historiography be written? 


\section{Notes to Chapter Three:}

1. Ochieng (1974),

2. Ki- Zerbo (1957), p. 67 :

3. Biobaku (1959), p. 99.

4. Nkrumah (1964), p. 10.

5. for a refutation of this point, see Ki- Zerbo (1957), p. 34.

6. Césaire (1970), p. 160.

7. This was the case e.g. in Tanzania; see Denoon \& Kuper (1970) for a lucid analysis of this neglect.

8. Biobaku, quoted by Wallerstein (1973), p. 87.

9. Ki- Zerbo (1957), p. 53.

10. Ki-Zerbo (1957), p. 53: "De même, les collectivités et les peuples sont le fruit de leur histoire. L'histoire est la mémoire des nations".

11. Kake (1964), p. 76.

12.Dike (1964), p. 23.

13. Cheikh Anta Diop's opinion paraphrased by Moniot (1962), p. 124 .

14.Dike (1964), p. 22 .

15. see e.g. the significant title of the article by B. Dougala (1972):

"Des ancetres fondateurs aux présidents modernes: continuité historique".

16.Ki- Zerbo (1972), p. 29.

17.one of the "Resolutions concerning the philosophy of African history" taken at the International Congress of African Historians held at University College, Dar es Salaam, Oct. 1965, was "that African history must be the basis of civic education".

See Ranger (1968), p. 219.

18. Kake (1964), p. 77 .

19. Kake (1964), p. 78.

20. Tchikaya in Table Ronde (1972), p. 123.

21. idem, p. 57.

22.Dike (1964), p. 22; N'Diaye (1973), p. 40; Diop (1964), pp. 48-9: "African historians must do more than just dig down beneath the surface of Africa, which apparently has some rather pleasant surprises in store. As persons destined to educate our people, they must provide a structural pattern for the national consciousness, as well as the consciousness of African as a whole". 
23. see Assorodobraj (1967), p. 13; Ajayi \& Alagoa (1974), p. 129

24. Biobaku (1959), p. 99.

25. see Vansina, Mauny $\%$ Thomas (1964), p. 82.

26. Soyinka (1970), p. 140 :

27. Ranger (1968), p. xxi.

28. idem.

29. Maybe the historians did identify with the cause of nationalism longex than e.g. the creative writers, since they actually belonged to the elite in power, in their functions of Professors, Chancellors and Vice-Chancellors of Universities.

30. Hopkins (1976), p. 31.

31. Tchikaya in Table Ronde (1972), p. 75.

32. Dike (1974), p. 2.

33. Ajayi \& Alagoa (1974), p. 131.

34. Ajayi \& Alagoa (1974), p. 132.

35. ibid. p. 131 .

36. ibid. p. 132 .

37. Ochieng (1974), p. 45.

38. ibid. p. 46.

39. ibid. p. 48.

40. ibid. p. 47

41. ibid. p. 48.

42. Ranger (1976), p. 23.

43. Ochieng (1974), p. 56.

44. Ayandele (1969).

45. Ki-Zerbo (1969), pp. 129- 30.

46. ibid. p. 142.

47. Simon (1969), pp. 58- 69. 
CHAPTER FOUR

The Manifestoes Revisited:

How African History should be written.

It is not accidental that African historians devoted themselves almost exclusively to the study of Africa's past. This was the logical consequence of the fact that they regarded their historical research as their contribution to national reconstruction. Writing African history from an African perspective had obvious methodological implications: The historian should not only, or mainly, depend on external, European sources but was to use internal, African sources as well-both written and unwritten. In view of the relative scarcity of written sources for African history prior to the era of colonialism, the African historian was to call upon other (sub-) disciplines for archaeological, anthropological and linguistic data. Looking at those (parts of) manifestoes dealing with the methodology of African history, one cannot excape the conclusion that 'once you've read one, you've read them all', but let us not get ahead of the argument and turn to an analysis of how African historians thought they should go about writing African history.

1. The Inter-Disciplinary Approach

They all agreed that the approach to African history should be inter- disciplinary or multi- disciplinary. The African historian should bring all kinds of sources--not only written--to the study of the African past; he should call in the techniques of all kinds of disciplines to procure sources for retracing this past. Oral traditions were considered the most important type of unwritten internal sources for the historian of Africa, but of crucial importance as well--in particular to the establishment of a chronology of African history--were archaeology and linguistics. Ethnography or anthropology were expected to illuminate the past by their techniques of studying the present. Art, musicology, geography, ethnobotanics, ethno- zoology, paleo-botanics and what have you, should be called in when necessary and possible. 
Usually African historians did not go into details when they discussed the indispensability of the inter-disciplinary approach ${ }^{1)}$. Even in practice--if I am allowed to anticipate for a moment--.--the inter-disciplinary character of the research projects which were actually set up was rather limited--even if historians did borrow linguistic and archaeological data from experts in these fields, and even if the collection and interpretation of oral sources--sources which are "enfermées dans le présent vivant" 2) -.-required the use of at least some anthropological techniques. African historians distinguished themselves from their colleagues active in the field of European or American history nainly by their: use of oral traditions. Therefore, the two major categories of sources of African history--the written and the oral sources--will be the subject of the next two sections of this chapter. It should be kept in mind that these sections intend to be both an inventory of the sources relevant to African history, and an analysis of the historians' attitudes towards these sources.

\section{The written Sources}

a. external written sources:

European written sources relevant to African history have been available from the late fifteenth century onwards. These were accounts of travellers visiting--and soon trading in--West Africa; reports of sailors, 'chefs de comptoir' and missionaries, which were complemented in the eighteenth century by those of the scientific expeditions sent out to report on Africa's geography, ethnography and natural history. From the nineteenth century onwards there was an increasing amount of 'official', i.e. administrative papers, which made up the bulk of the written sources available for the history of Africa in the colonial period.

The specific features of these sources--their tendency to stress the unusual, the curiosities of the African scene; and their ethnocentrism--have been amply discussed by others. Let us just note their limitations:

First, they were 'limited' in the sense that they were written from a Eurocentric perspective. Furthermore, they were limited in scope, range and interest: In scope, since they did not go back further than the late fifteenth century; in range, since up to 1800 
they dealt only with the coastal areas of Africa; in interests, finally, since they dealt mainly with trade and African systems of government ${ }^{3}$ ).

African historians--realising that these were the documents that had been of formative influence upon Europe's false image of Africa-were very critical of these sources and denounced their bias and racial arrogance. Yet, they all relied heavily upon them for reconstructing a fragment of the African past.

Another type of external written sources is made up by Arab documents ${ }^{4}$, i.e. documents written by authors belonging to the Arab world. They cover the period from the eight to the fifteenth century, when Europe had hardly any contacts with Balck Africa. They are mainly 'geographical' works, falling into four distinct categories:

- The science of longitudes and latitudes ('ilm al-ațwāl wa'l-'urūộ),

- The science of the position of countries ('ilm taqwim al-buldān):

- the science of routes and kingdoms ('ilm al-masālik wa'l-mamālik), and

- the science of the marvels of countries ('ilm 'ajā'ib al-buldän) 5). Their authors-- Ibn Hawqal (988), al-Mașūdi (957), al-Idrísí (11001164), Abu'l-Fída (1273-1332), al-'Umarī (1340), Ibn Bațūta (1350), Ibn Khaldūn (1332-1406), Leo Africanus (1492), a.o. 6) --were mainly interested in topics such as the type of government, the nature of the armed forces, the character and direction of foreign trade, the boundaries of kingdoms and the extent of Islamisation, and were by no means less ethnocentric than Europeans reporting on Africa. Those Arab documents that were known to European scholars during the colonial period, received fairly much attention--written sources being the stuff of history, after all. After 1960 the edition, annotation and publication of Arab documents by Africanists from Africa as well as from the West received a new impulse. At the same time systematic attempts were made to discover and collect Arab documents that were as yet unknown. This is even more vaild for the next category of written documents: the internal sources written by Africans mainly in the Arabic language, but also in vernacular languages (Haussa, Peul, Swahili, Somali) using the Arabic script.

b. internal written sources:

A systematic collection of these documents from 1960 onwards 
has brought to light an amazing amount of material written in Arabic. Several centers and institutes have been founded for this purpose (e.g. the Centre of Arabic Documentation at the University of Ibadan, Nigeria), while most History Departments of Universities situated in Muslim (parts of) African countries are active in this field (e.g. the Ahmadu Belio University in Zaria, Northern Nigeria and the Islamic Studies Department of the IFAN in Dakar).

The 'internal' written material is of various kinds. For West Africa it consists of chronicles, such as the Kano chronicle or the famous Tärỉkh al-südän (History of the Sudan) by al-Sa'di. Secondly, of the works related to the period of the Fulani jihads, many of them dealing with religious (Islamic) issues. There is a third category, that of correspondence, while official documents (Iandgrants or grants of privileges conferred by a ruler upon certain families) go into a fourth category. Finally there is much poetry both in the vernacular and in Arabic ${ }^{7)}$.

-material written by Africans in an African script.

Apart from Arabic and apart from their own language transcribed in the Arabic script, Africans have used scripts designed by themselves. In West Africa, for example, there were the vai and Bassa scripts of Liberia; the Nsibidi of the Nigerian Efik, the Bamoun script of Njoya (Cameroon). According to Cornevin however, "elles sont relativement récentes et n'offrent pour l'histoire locale qu'un intérêt très limité" 8). -works composed by Africans during the colonial period--both in the vernacular, using the Latin alphabeth, and in French and Engiish-have been characterised above ${ }^{9)}$.

This section has gone far to show, I hope, that African history can be reconstructed at least to some extent from 'internal' written sources. Yet, for the African historian who set out to write this history from an African perspective--particularly when dealing with the precolonial period--oral sources were indispensable. These will be the subject of the next section. 
3. Oral Sources

No wonder African historians did not elaborate on the methods of using written sources for historiography, methods which had been well established in European historiography long before the 1960 s. With regard to oral traditions the case was different. Prior to the early sixties, the international community of historians had overtly denied the value and validity of oral traditions as source-material for history. Initially African historians spent more energy and time on vindicating the value of oral traditions than on the methodological question of how to handle (i.e. to collect and interpret) them.

After the publication of Vansina's methodological treatise "De la Tradition Orale" in 1961, the apologetic tone of those (parts of) manifestoes dealing with oral sources became less emphatic. However, instead of stimulating a discussion of methods, Vansina's study was considered to have absolved the African historian from this difficult task ${ }^{10)}$.

The polemical or apologetic tone of the theorericians of oral traditions was not only determined by the time of writing, but also by the place of writing and by the audience the historian was addressing. Once the African historians addressed an African academic public in African and Africanist periodicals the need for apologetic treatises on oral sources became less obvious.

The rather apologetic tone of the historian J. Ki- Zerbo, from Upper Volta, even as late as 1969 and 1972, may be explained by two factors: First, he was writing a general "Histoire de Monde noire", and addressing a wide international public. Secondly, as a historian who graduated before independence, and as one of the 'parisianised' or frenchified intellectuals he was very close to the Négritude movement which in a sense represented the 'negative' rehabilitating phase of African nationalism. Howbeit, his flowery defense of "une histoire polysource", in which oral tradutions were to figure most prominently, was a far cry from the practical treatises of Anglophone historians such as Afigbo, Alagoa and Asiwaju, who gave a practical account of their experiences in the field 11), Ki-Zerbo's argument was much more 'academic'; making a virtue of need he contended that there was no need to regret the scarcity of written sources for African history; for, even if these would have been more numerous: 
"l'image qui en résulterait serait nécessairement tronquée car la plupart de ces documents ne proviennent pas des profondeurs mêmes du peuple africain..."

(...)

"Alors, force nous est de nous rallier par conviction comme par nécessité à l'école historique la plus moderne, la plus compréhensive, la plus apte à récupérer tout le passé, celle des tenants de l'histoire totale". 12)

As we have mentioned above, oral traditions--defined by Vansina as "oral testimony transmitted verbally from one generation to the other or more" 13) --were to be the major source of an "histoire polysource". Ki- Zerbo indentified and denounced three categories of academic enemies of oral traditions ${ }^{14)}$. The writing-fetishists ("les fétichistes de l'écriture"), the "chronophiles", and the functionalists.

As for the writing-fetishists, for whom history was unthinkable without written sources, they had been defeated long before African historians appeared on the scene, Ki- Zerbo said, a.o. by the historians grouped around the historical journal of the "Annales"; while Vansina's book "De la Tradition Orale" gave them a final and fatal blow. With this category African historians had only rearguard actions to fight.

The chronophiles, rejcting oral traditions as historical sources for their lack of historical precision, were more considerable enemies, since they pointed at the major weakness of oral evidence. This much was admitted by two Africanists who were actually devoting much of their time to remedy this weakness, and to find ways to convert the relative chronology of oral traditions to the absolute chronology of literary history: The French historian $Y$. Person and the Nigerian E.J. Alagoa ${ }^{15)}$. Their recognition of the problematic features of oral traditions--the lack of clear chronological references, their "evenemential" nature (i.e. emphasis on events instead of processes, schools of thought, long-term developments, structures, etc), their bias for things political--appeared more plausible and eventually proved more fertile than attempts made by others 16 ) to gloss over these problems.

Again Ki-Zerbo comes to mind. Allegedly, the absence of chronological precision was not very regrettable, for:

"I'histoire historisante des dates de batailles, de traités d'évenements et de chutes de rois ou presidents de la république est longuement passé" 17). 
Ki- Zerbo identified a third category of enemies of oral traditions, that of the "functionalists", who

"prétendent que la tradition est transmise dans un but utilitaire précis, en vue de remplir une fonction donnée, pour un group social déterminé $(\ldots)$ Elle relève donc tout au plus de l'anthropologie culturelle ou juridique de l'histoire des idées et non de l'histoire des faits réels". 18).

Ki- Zerbo referred here to 'colonialist' anthropologists such as R.H. Lowie. The "new functionalists" within the African camp 19) however, were far from denying the value of oral traditions or from dismissing them as "only myths". They set out to analyse the social and historical context which determined the oral tradition's ultimate form. They compared the different versions of a tradition--versions collected from different social groups, or versions collected at different dates or places--in order to relate the changes of the tracition to the social and political history of its custodians. Instead of denying or glossing over the subjectivity of oral evidence --for example their practical (legitimising, moralising, etc) purposes--"functionalists" such as Dike and Asiwaju attempted to use the subjectivity expressed in the different versions as a key to the (conflicts of the) past. They contended and demonstrated that it was only by a "functional" or sociological analysis of the different versions that oral traditions could be forced to yield information on the history of ideas and on the "real facts". The methodological implication of this approach was a more systematic collection and comparison of different versions of oral traditions.

The African historians' attitudes towards oral traditions kept pace with the evolution of their concept of what African historiography should be. The trend away from a "Eurocentric" history of Africa towards one focussing upon the internal evolution of African societies implied a more intensive ana exclusive use of oral sources. The trend away from political history and consensus history necessitated a more systematic and comprehensive collection of oral traditions, from the common people as well as from chiefs, kings and other privileged social and political groups.

Concluding one tends to agree with Ranger, who said--assessing the results of fifteen years of African historiography--that the methodological discussion on oral traditions had not made any substantial progress since Vansina's "De la Tradition Orale", and that the 
discussion had only recent] y been reopened ${ }^{20)}$. Even if this holds true for the theoretical side of the story, on a practical level progress has been made.

The field experience of scores of African historians who collected oral evidence in the decade following independence is indispensable to the present reopening of the methodological discussion to which Ranger referred.

Obviously, the manifestoes about the kind of history one interded to write were not necessarily identical with the historical works which were actually written. After all, the manifestoes were more often than not phrased in rather rhetoric language, and full of stereotypes; products of the euphoria and optimism that attended the achievement of independence.

The remaining part of this essay will focus upon the historiography of the largest West Africa country, Nigeria. Nigerian historiography--written by Nigerians--can be regarded as representative of African historiography in general, I feel, in the perspective from which it was written, the sources on which it was based, and in its major themes. Yet, in one respect it is not representative: its size. Both the number of historical works published in the period under study, and the number of professional historians are much larger than those of other Anglophone and Francophone countries of West Africa 21 ). 
Notes to Chapter Four:

1. more information can be found in "The Historian in Tropical Africa" (1961); Gabel \& Bennett'(1967); Vansina (1961), Ch. 6:3; MC CalI (1969); Vansina (1968); Dike (1964a).

Alagoa (1975) distinguished three different ways of organising interdisciplinary research:

-1. Scholars of different disciplines working together in the field.

-2. Scholars of different disciplines working under the direction

of one general director, not necessarily a historian.

-3. The so-called "one- skull" approach whereby one person has command of the techniques of various disciplines.

2. Moniot (1962), p. 138.

3. Hodgkin (1975), p. 3 .

4. The term "Arab" is used here in the sense of 'being written by authors belonging to the Arab world' and should be distinguished from the wider category of "Arabic" literature which included the Arabic writings of West Africans. The definition is Hodgkin's (1975).

5. Hodgkin (1975), p. 3 .

6. Cornevin (1960) gives a long list of Arabic geographers and travellers relevant to African historiography from the 8th to the 15 th Century. See Cornevin (1960), pp. 29-30; see also Ki-Zerbo (1972), pp. $13-4$.

7. Hodgkin (1975), pp. 9- 12.

8. Cornevin (1960), p. 51.

9. See above, Chapter One pp. 9/10.

10. compare Ranger in Fyfe (1976), p. 18.

11. see Alagoa (1966, 1966a and 1966-67), Afigbo (1966) and Asiwaju (1976a).

12. Ki- Zerbo (1969), p. 129.

13. Vansina (1962), p. 444.

14. Ki- Zerbo (1972), p. 17

15. Y. Person (1962); Alagoa (1966a).

16. Apart from Ki- Zerbo see Cornevin (1960) and Deschamps (1962), who wrote: "Sauf exceptions (nombreuses d'ailleurs) l'individu ne joue que exceptionnellement un róle dans le passé africain.

Nous avons affaire à des masses, parfois stratifiées souvent homogènes, dont nous ne pouvons retracer l'existence et l'evolution qu'en bloc. L'histoire "non- événementielle" ici est la règle et l'aspect le plus aisé à saisir" (Deschamps, p. 114).

17. Ki-Zerbo (1969), p. 140.

18. ibid., p. 132 .

19. Asiwaju (1976); Niane (1974); Dike (1973); Afigbo (1966). Essentially this "functionalist" method was none other than Vansina's.

20. Ranger (1976), pp. 18- 9 . 
21. Nigeria is the most populated country of Africa. Arnold (1977, p. vii) estimated its population at 78.7 million at the beginning of 1976 . "Africa South of the Sahara, 1076-77" (1976, p. 635) gives an estimate of 62.925 .000 in 1975 .

Nigeria has an area of .350 .669 square miles, 10 Universities and 3 University Colleges. 
PART TWO

Nigerian Historiography, 1955-1973 

General Introduction to Part Two

Before we proceed to the actual discussion of Nigerian historjography from 1955 to the early seventies, a few words need to be said about the way in which this survey has been set up.

In this essay Nigerian historical studies have been classified according to the period with which they dealt. Four categories--to be discussed in four chapters--have thus been distinguishea:

Chapter Five: The historical studies dealing with the late precolonial past, the period of the European, conquest of Africa (1850-i900).

Chapter Six: Historical studies dealing with the early pre- colonial past, the period prior to the European presence, or at least to the European dominance (1500-1850).

Chapter Seven: The historiography of Nigeria's colonial past up to 1945. Chapter Eight:Historical studies of the period after 1945 (1945- 1973 ).

Within these categories a thematic approach has been followed in discussing the major works of Nigerian historiography individually. 
CHAPTER FIVE

Nigerian Academic Historians and the Late Pre-Colonial Past: 1850-1900.

-african reaction to european action: the continuity of history restored-

Introduction

The first Nigerian professional historians, who obtained their Ph. D. degrees before or shortly after independence, were without exception British-trained. S.O. Biobaku, K.O. Dike, and J.F.A. Ajayi all took their doctor's degrees before 1960, the year of Nigeria's independence. J.C. Anene, T.N. Tamuno, J.A. Akinjogbin and E.A. Ayandele all obtained their British Ph. D. degrees between 1960 and 1965 .

Without denying the particularity of the work of each historian, it is possible, I believe, to distinguish some common features in these specimens of early Nigerian historiography. After all, the historians were not only trained in the same (British) tradition of research, but also shared a common commitment to the--almost or recently--independent nation.

The first striking aspect was the fact that the first academic historians all dealt with roughly the same period of time, namely, with the transitional period from European 'informal' to 'formal' empire, in which Africa's political independence was lost. It is not accidental that this period received so much attention: There was the practical question of sources, first of all: There was not only an abundance of untapped archival sources for this pexiod, both in Britain and in Nigeria itself, this period was also still very much alive in the oral traditions of Nigeria's different ethnic groups, since many of those who had actually lived through the colonial period and had been eye- witnesses of its events, were still alive. This factor in itself is not sufficient to account for the preoccupation with the period of European occupation. After all, the colonial period, for which archival sources were equally abundant and oral 
traditions as vividly remembered, was neglected in this early phase of Nigerian historiography. In combination with the historians' obsession with the search for origins and their stated purpose of restoring the continuity of African history (see pp. 24ff), the abundance of sources clearly favoured the study of this late pre-colonial period. It was this period 'that the colonial power, which was moving out at the time of writing, had become rooted in Nigeria soil; that the independence, which was regained at the time of writing had been lost. It was in this period that the resistance to European interference, which bore fruit at the time of writing, had originated; that the roots of the nationalism which triumphed in 1960 were to be found. It was with this period, which witnessed the last independent "Nigerian" states, that the new nation-state had to link up, in order to refind its identity, authenticity and inspiration for the future. It was the study of this period, finally, that could disprove the myths of African passivity and primitiveness.

The choice of period was not the only feature the first Nigerian historians had in common. Secondly, they all wrote 'Nigerian' history, that is to say, all studied one particular ethnic group or area--more often than not the historian's own ethnic group or native region-forming part, of the modern Nigerian state ${ }^{1)}$. Although it may not be evident from the titles, all studies dealt with Southern Nigeria, particularly with South Nigeria's largest ethnic groups the Ibo and the Yoruba. This neglect of e.g. Northern Nigerian history was not typical of early Nigerian historiography only, it should be noted, for this imbalance was not to be remedied until the early seventies.

There was a third common feature of the early historiography: the sources on which it was based. European written sources---the metropolitan archival material of the Foreign and Colonial offices, and the missionary records--formed the mainstay of the works. But these were counterbalanced by the local archives (both in the former colonial capital and in the divisional and district capitals); by local, private papers, mainly family papers in the possession of descendants of 'eminent nineteenth-century Nigerians'; by 'local histories', written by 'local', or 'spontaneous' historians (mentioned on pp. 9-10), who were described by K.O. Dike as follows: 
real sense. The lag in educational development of Northern Nigeria-part of its colonial heritage--was responsible for the absence of Northern Nigerian equivalents of British-trained 'pioneer' historians such as K.O. Dike, S.O. Biokabu and J.F.A. Ajayi. It was responsible as well for the absence of universities in the North at a time when the Southern universities yielded a yearly crop of historians who had by then devoted two or three years of intensive research to one particular area or ethnic group--usually the author's own ethnic group, since this facilitated the collection of oral evidence--of Southern Nigeria.

One vexed question still remains to be answered before we turn to the analysis of the individual historical studies: Must the historical studies in question be regarded as ideological or nationalist history?

The answer cannot but be premature in this early stage of our survey. But on the basis of what has been said so far, one cannot say that there was question of one-sidedness or nationalist bias as far as sources and tone are concerned. The absence of a nationalist bias was manifest as well in the geographical framework of the historical studies in question, for none took the Nigerian nationstate as the --necessarily anachronistic--framework of studies of the nineteenth century past. On the contrary, the historians have been sharply criticised for limiting their studies to a region or ethnic group: Their approach was denounced as "a tribal approach" and one making for disunity instead of unity ${ }^{6)}$.

On the other hand the tenor of this early historiography was nationalistic in this sense that it betrayed a preoccupation with the nation-state, and with making historiography relevant to the new nation.

The bias for things political, the overemphasis on the transitional period in which African independence was lost, and the obsession with continuity were unmistakably imbalances inspired by and resulting from the historians' 'nationalist' concern to make the past usable in the present.

The main purpose of this essay is not to trace nationalist biases or misinterpretations of Nigerian historiography, thus contributing to the belief that "an Africanist is a specialist whom we employ to get the better of Africans" 7). In comparing the focus, themes, 
sources, space-scope, time-scope and tone of Nigerian historiography, I have attempted to reveal their common features. In order to demonstrate that these common features were not accidental, I have attempted to relate them to the historians and the environment in which they wrote.

Common themes:

5.1: African Reaction to European Action: Resistance to imperial control, in

a): Southern Nigeria: The First Nigerian Academic Historians and the History of Southern Nigeria.

K.O. Dike's Trade and Politics in the Niger Delta, 1830-1885 - an introduction to the economic and political history of Nigeria" was the first book written by a Nigerian professional historian to be published ${ }^{8)}$. It dealt with the transitional period (1830-1885) in which Britain changed its African policy from non-intervention to active interference in the states of the Niger Delta (part of modern Southern Nigeria). Because of the rather limited use of oral evidence apart from metropolitan and local archival sources and private papers, it was typically an early work. But even if the sources on which it was based were conventional at the time of its publication, the book's focus was revolutionary. This focus was African, centering upon African reactions to European activities. British merchants and consuls still figured prominently in the pages of the book, but the principal actors were the rulers of the coastal city-states, both the traditional ruling elite and the 'nouveau riches'.

Three main themes can be distinguished:

1. First of all there was a critical analysis of the reasons and motives of British encroachment and the means by which it achieved. This was the British side of the story: Although recognizing non- economic factors such as humanitarianism, missionary zeal, love of adventure, etc., Dike regarded Britain's changing economic needs as the determining factor for the drive into the interior. Thus he explained the transition from a predominantly slave-trading economy to one based on the trade in raw materials of the West African 
forest from the fact that in Britain:

"...the new industrial order demanded above all markets and raw material for the rising output of British factories" 9).

2. The impact of British presence and penetration inland upon the Delta states, and the reactions of the African "merchant- princes" to this penetration formed the second theme, representing the African side of the story. According to Dike:

"British prohibition of the slave-trade--the economic mainstay of the coastal principalities--soon brought corresponding changes on the social and political planes" 10).

Since Britain now aimed at partnership with the hinterland Africans, the coastal middlemen had to be removed. This was a revolutionary change, since for 400 years (1481-1807) the Europeans had been confined to the coast, allegedly owing to African attitudes to land and the opposition of the coastal chiefs who had excluded them from the hinterland. With the abolition of the slave-trade, which became effective in the 1850s,

"the 400 years old political systems built on the slave trade generally declined and by the 1880's collapsed" 11).

The coastal merchant-princes--even if eventually unsuccessful--gallantly resisted this abandonment of the old abstentionist policy in favour of the new policy of penetration. These resisters, men such as Dappa Pebble and Jaja of Opobo, whose resistance was finally broken by "gunboat diplomacy", figured prominently in Dike's book. This time they were not described from the perspective of British (contemporary) observers, who had considered African resisters as enemies of progress and civilisation, but from the African point of view, criticising the violent means and destructive results of British penetration.

3. Throughout his book Dike praised the sophistication of the coastal city-states; their efficient organisation of trade through market-laws and the House-system 12), the adaptability and suitability of their strong and despotic governments to the semi-military society of the time ${ }^{13}$ ). This was the third theme of the book. There can be no doubt as to where Dike's sympathies lay, but in spite of his critical attitude towards the British, his tone was not overtly hostile. One of his most direct criticism was phrased as follows: 
"It is a matter for reflection that little of permanent value came to West Africa from the 400 years of trade with the Empire" 14).

This certainly was a very polite way of accusing Britain of 400 years of cheating. This restrained tone was quite typical of early Nigerian historiography.

Let us now turn to a small book which appeared in 1960 and was called "Eminent Nigerians of the Nineteenth Century - a series of studies originally broadcast by the Nigerian Broadcasting Corporation. Seven of the eleven sketches of "Eminent Nigerians in the Nineteenth Century" were written by eminent twentieth century Nigerian historians, a.o. K.O. Dike and S.O.Biobaku. As a 'popular' historical work this book is actually beyond the scope of this essay. Yet, a look at some of the criteria for nineteenth century eminence as formulated by historians of the 1960 s may prove very illuminating.

The sketches of "Eminent Nigerians" were side-products of more elaborate historical works, and as such they can be regarded as indicators of a much larger body of historical studies. As in the major studies of the authors of "Eminent Nigerians", the period under study was the nineteenth century, which presented "an interesting contrast to our own times" 15) as Dike put it, since it witnessed the loss of independence which was regained in 1960. As in the major studies, the book's central theme was the familiar one of African reactions to European intrusion. This was the theme of all but two chapters of the book, namely those on "Utman dan Fodio and el-Kanemi, both architects of large pre- colonial political units in the West African Sudanic belt. The resisters, e.g. Oba Overami of Benin, Nana the Itsekiri chief and Jaja of Opobo, occupied the scene in some chapters, whereas the cooperators--both from among the educated 'missionary' elite (here represented by S.A. Crowther, the first African bishopl and from among the local ruling elite--featured in other chapters. While the myths of African passivity and of the primitiveness of its political systems could be disproved by the story of primary resistance--e.g. by referring to Nana's well organised trading empire-the story of 'collaboration' could serve to show the formative influence of African internal factors upon the actual course of 
of events in Southern Nigeria. That a positive or negative reaction to European interference was dictated more often than not by questions of internal political rivalry was illustrated by the case of King William Dappa Pebble, who called in the British to get ria of the usurper of his throne.

What criteria were applied in selecting nineteenth century Nigerians for this honorific title "eminent"? What did it require to qualify as "eminent"? The necessary qualifications were not explicit, but some close reading yields the following: First of all, "eninence" required strong moral fibre. El-Kanemi e.g. was said to have been:

"A brave man, a wise man, a good man--such was el-Kanemi-a paragon, one may feel, of a ruler" 16).

secondly, one could qualify as "eminent" on the basis of a traditional or newly acquired high social position; that is to say, royal blood or political or commercial achievement. Nana the Itsekiri chief, for example, was considered "eminent" because of his wealth, his power, and his brilliant initiative in organising his trading empire. A third way of qualifying for the honorific title "eminent" was the sheer possession of power. This accounts for the inclusion of Umaru and Ibrahim Nagwamatse in the book. who:

"where neither good nor wise; they were both soldiers of fortune, men who (...) loved fighting and rejoiced especially in that meanest and cruellest of all forms of warfare--slave raiding" 17).

Fortunately, one of them at least had the advantage of having resisted European penetration.

This brings us to a fourth and final way in which a nineteenth century Nigerian could qualify as "eminent", namely, by active resistance against European encroachment. More than half of the "Eminent Nigerians" featuring in the book were resisters:

Dike described Pebble as a man "of very independent turn of mind", "who resented British encroachment" 18), and was "Britain's greatest head-ache in the Bight of Biafra" "the last truly independent king of Bonny" 19). J.C. Anene described Jaja as a man who used his talents "in the defense of his commercial interests against European encroachment" 20). Biobaku called Kosoko of Lagos "a prince, warrior and consummate trader" and "a handsome and refined dealer 
in the slave trade", who "put up a gallant defense" against the British gunboats 21 ).

Were these "Eminent Nigerians" indeed eminent in the eyes of their nineteenth century contemporaries? Or were they only eminent in the eyes of twentieth century Nigerian historians, as E.A. Ayandele argued when he criticised the book nine years later 22). We have seen that the authors aplied at least four criteria for "eminence", of which anti-European resistance was only one. Yet, they set great store by this resistance, ignoring the fact that this resistance was not ipso facto evaluated positively by West African contemporaries. In this sense the authors were indeed reading the present back into the past. The same danger of writing anachronistic history was imminent in their concern to demonstrate the continuity netween nineteenth century "Eminent Nigerians" and twentieth century Nigerians ${ }^{23}$, not so much in order to illuminate the past. but to serve present needs.

Highlighting African reactions to European control was not the prerogative of the first, London- trained Nigerian historians. The same theme was central to a study by 0 . Ikime, who obtained his Ph. D. in Ibadan in 1965. His book was entitled "Merchant Prince of the Niger Delta - the rise and fall of Nana Olomu, last governor of the Benin River". It was published in 1968 and was apparently written for a wider public than academic circles only. Both because of the genre to which it belonged (biography) and because of its subject (a resistance fighter) it was very suitable to popularise knowledge of Nigeria's past.

Although Ikime was writing later in time, the similarities between his study and earlier ones such as K.O. Dj.ke's book and "Eminent Nigerians" were striking. The main difference was Ikime's explicitness.

This was manifest in his criticism of British interference in Southern Nigeria; criticism that was much more outspoken than that of K.O. Dike for example, whose study can be regarded as a classic example of careful, cautious and polite scholarship. Secondly, while the authors of "Eminent Nigerians" had pointed at parallels and contrasts between the nineteenth century and the period 
following independence, Ikime argued the existence of a direct continuity:

"It is now generally recognised that the beginnings of nationalist struggles in Africa date back to the nineteenth century when various African leaders spearheaded the resistance movement against European economic exploitation and political domination" 24).

Again, Ikime defined the importance of the principal character of his study--Nana Olomu, rulex and trader of the Itsekiri, who resisted British interference--explicitly in terms of Nigerian nationalism. While T.N. Tamuno, another Nigerian historiar, refused to bestow the honorific title of "African nationalist" on Nana in view of the sectarian and selfish nature of Nana's resistance and the fact that he did not even command the support and sympathy of all Itsekiris 25), Ikime, insisted on doing so. After ail, "no nationalism is ever completely divorced from this kind of self-interest" 26), he argued apologetically. Since Nana was head of the Itsekiri people, Ikime saia, his resistance to imperial control was "in a sense 'national' in the Itsekiri context" 27).

"in the final analysis the fact remains that what Nana and others like him stood for on a limited plane in the late nineteenth century was in essence what nationalists in the period after 1914 were to fight for on a larger plane, the freedom of alien control" 28).

It is tempting to dismiss this debate on whether the 'primary' resisters were African nationalists or not as a question of terminology only, which in a sense it was. Yet, this debate is significant because it reveals that Ikime was again very much concerned with tracing the roots of modern nationalism, and with restoring the continuity between the pre- colonial past and the post-colonial present, thereby rehabilitating the past and legitimising the present.

5.1: African Reaction to European Action: Resistance to imperial control, in

b): Northern Nigeria and the West African Sudanic Belt:

Studies of Northern Nigerian reactions to European advance appeared relatively late, as we have seen above (pp. 47-8). R.A. Adeleye's study "Power and Diplomacy in Northern Nigeria, 1804-1900 - the Sokoto Caliphate and its enemies" was published in 1971 in the the Ibadan History Sexies. Adeleye defined the central theme of the book thus:

"The main emphasis is on how and why the caliphate met the European challenge the way it did" 29). 
The book consisted of three parts. In the first part (Chapters 1-4) Adeleye described the internal structure of the Caliphate, particularly its elements of stability and instability and the specific nature of its unity: The Caliphate of sokoto consisted of emirates which all had a high degree of autonomy in their day-to-day affairs, especially defence. They were all "microcosms of the sokoto model", Adeleye argued, and their 'localism' or provincialism--though a barrier to effective centralisation--was not contradictory to unity and not a sign of internal disintegration or decline. Its failure to survive as an independent political entity was in the last resort due to the Europeans:

"... Superimposed (...) upon the problem of defense against its traditional enemies, which the Caliphate could cope with, albeit with considerable inconvenience, was this new and bigger problem of infiltration and encirclement by foreign enemies-the agents of European imperial expansion" 30).

The second and third part of the book (called resp. "Relations with Europeans during the Scramble Era" and "The British Overthrow of the Sokoto Caliphate") focussed upon the question why the different emirates did not take concerted action in resisting the Europeans. Sokoto fell rather easily, Adeleye had to admit. Yet, he strongly rejected:

"the tempting conclusion (...) that African armies which fell easily to such European-led forces did so because of lack of determination to resist the European onslaught" 31)

What then was the real reason why the emirates did not combine in the face of the European threat?

Adeleye put forward a number of reasons, such as the specific nature of the unity of the sultanate, explained in the book's first part; the fact that there had never been a general threat to the Caliphate as a whole prior to 1800; the impression that the Caliphate was encircled by hostile forces (by the French as well as the British); and, finally, British policy of piecemeal occupation and tactics of isolating the emirates from one another. Adeleye's analysis was quite detailed and convincing, Yet, its tone was unmistakably apologetic. His attempts to rehabilitate the sokoto Caliphate--its political virility in spite of its decentralised structure, and its determination to resist the European onslaught, in spite of the ease with which it fell--remind one of the way in 
which the first Nigerian historians vindicated the sophistication and love of liberty of the Southern Nigerian coastal states.

The question of resistance to European control was foremost on Adeleye's mind: Not only did he vindicate Sokoto's determination to resist in spite of its rapid surrender, he even devoted the third part of his book to demonstrate the existence of widespread hostility to European rule in spite of apparent submission and loyalty to the British. This hostility, Adeleye argued, was both overt and underground; it existed both before and after the loss of sovereignty, and it existed both among the Emirs--some of whom rose into open revolt ${ }^{32}$ ) -and among the ordinary population. It was particularly this popular resentment at British conquest and the typically Islamic way in which it found expression, that were centrai to the third part of the book. This resentment found expression both in the rise of Mahdist movements, i.e. millenarian movenents which called all Muslims to its banner to recreate the Islamic Community of the Prophet's time, and in mass emigration of Muslims who refused to live under infidel rule.

This mass emigration, as Adeleye put it, "must be seen as, at least in part, a registration of protest against the British conquest" 33 ). It demonstrated "that there was enough popular resentment at British conquest on which to base popular anti- British risings" 34), had it not been driven underground by the presence of British troops.

The purport of the book cannot be misunderstood: Evein if sokoto was defeated, it did not submit passively or willingly to the European aggressors. As Adeleye showed, there was active or passive resistance on all levels. Secondly, even if the specific nature of the unity of the Caliphate was instrumental in bringing about its collapse and its subsequent failure to face the new situation resulting from European aggression, it had been adequate to the requirements of the pre-colonial West African environment. If Adeleye's study of the Sokoto caliphate could be called "Northern Nigerian" history (since the area under study roughly coincided with Nigeria's Norhtern Region as it took shape in the colonial period), other studies from his hand covered the West African Sudanic belt in general.

Adeleye's colleague in this field was B.O. Oloruntimehin, author of "The Segu-Tukolor Empire, 1848-1893" (which was published in 


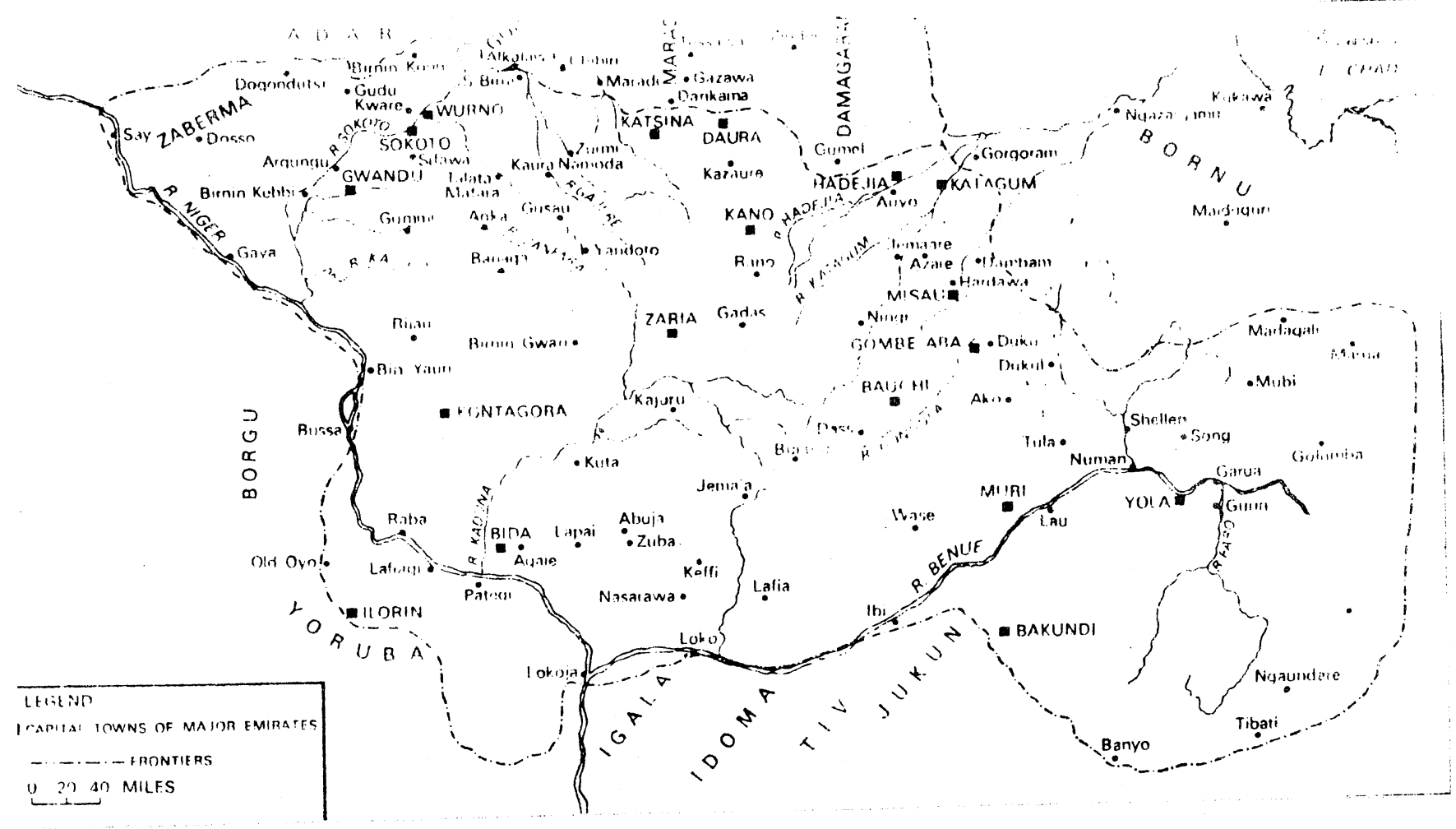

The Sokoto Caliphate: external frontiers from R.A. Adeleye (1971), "Power and Diplomacy in Northern Nigeria 1804-1900; the Sokoto Caliphate and its enemies", p. 67.

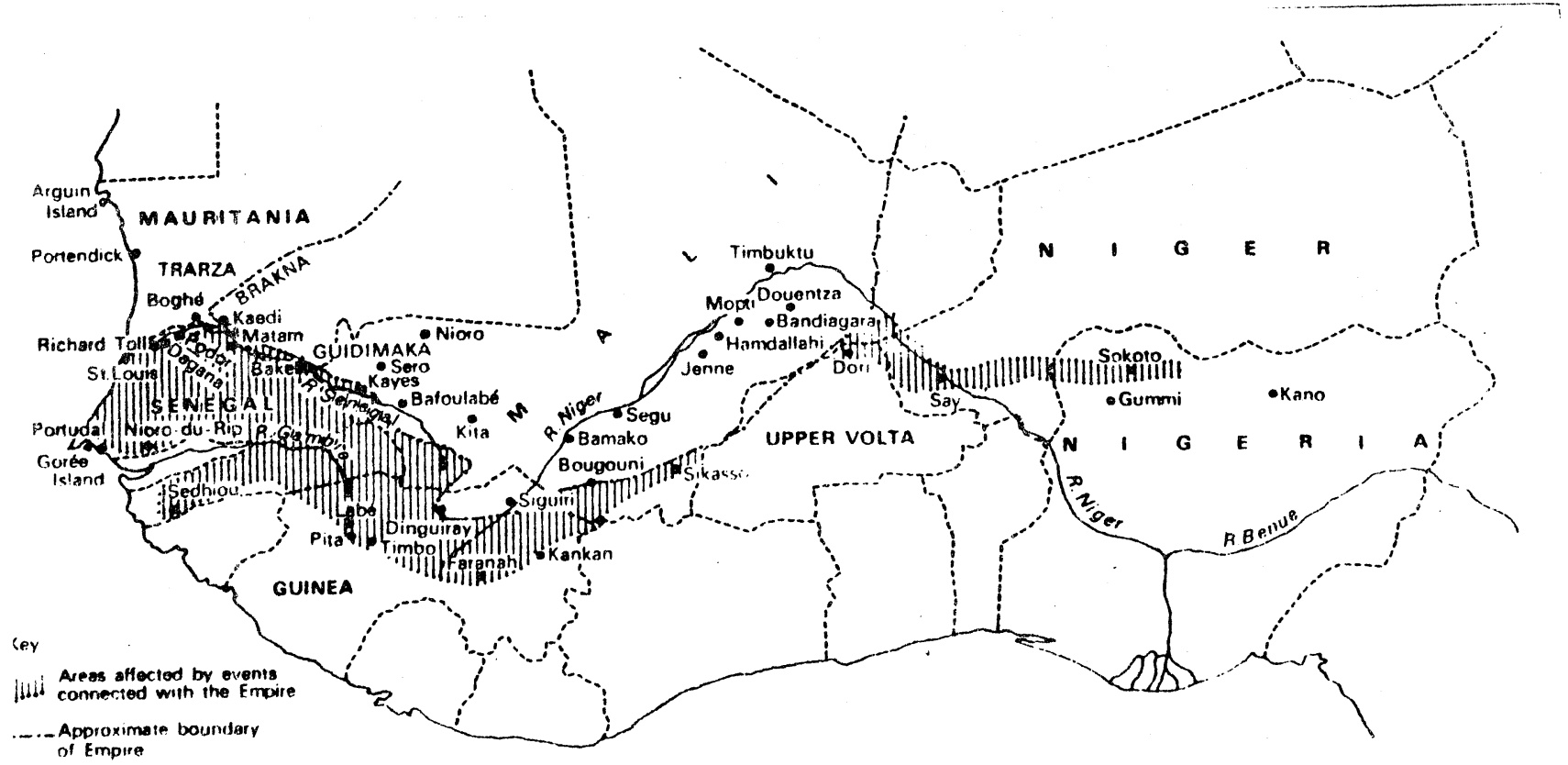

Contemporary states in the area of the former Tukulor Empire from B.O. Oloruntimehin (1972), "The Segu - Tukulor Empire", p. 319. 
1972) and many articles published in journals such as the Journal of the Historical Society of Nigeria (JHSN), Odu, African Notes, Cahiers d'Etudes Africaines, and others. As an Anglophone historian who knows French and who has devoted most of his research to the study of African reaction to the imposition of French instead of British rule, Oloruntimehin is quite unique. Yet in other aspects--such as theme and commitment--his work shows many similarities with the studies discussed so far. Adeleye and Oloruntimehin not only studied the same area and the same period, but also concentrated upon the same kind of historical problems. This is evident when one compares Oloruntimehin's article "Anti-French Coalition of African States and Groups in Western Sudan, 1889-1893" 36) wi.th Adeleye's study discussed above: While Adeleye tried to account for the absence of concerted action against the Europeans in the Sokoto Caliphate of the 1880s, Oloruntimehin described how elsewhere in the Western Sudan Africans did manage to make a large-scale cooperative effort at repelling Eurpean imperialism.

Oloruntimehin's major study "The Segu-Tukolor Empire, 1848-1893" (1972) demonstrated a similar concern with a nineteenth century west African experiment in political and social integration. This study, based upon the $\mathrm{Ph}$. D. thesis Oloruntimehin submitted to the University of Ibadan in 1966, was essentially a political history dealing with the period leading up to (and including) the French conquest of West Africa. It described the process by which the Tukolor-an ethnic group which played an important part in the history of Muslim West Africa--created their empire through a protracted revolution that lasted from 1852 to 1864. Much attention was paid to the problems involved in ruling the emerging empire, particularly the resistance of the conquered non- Tukolor ethnic groups and political units, and the rivalries within the ruling group. Finally Oloruntimehin analysed the Empire's fatal 'problem': advancing French imperialism, which eventually led to its collapse in 1883. Although oloruntimehin wrote several articles about French imperial diplomacy and African reactions to it ${ }^{37 \%}$, in this study French imperialism (which took up only $2-2 \frac{1}{2}$ chapters of the book) was not his major concern, nor African resistance per se. Central to the book was 
the question why the Tukolor experiment in empire-building had failed. Oloruntimehin's conclusion at the end of his ninth chapter was this:

"Thus its ruinous internal conflicts and the superior weapons of its enemies (i.e. the French) brought about the fall of the Tukolor empire" 38).

Oloruntimehin admitted the grave consequences of the internal tensions of the Empire. Yet, he regarded "the fact that it existed in the period of, and struggled continually against, the high tide of European imperialism" as decisive:

"... it should not be surprising that the Tukolor experiment in large-scale political and social integration did not last longer than it did. The Tukolor needed more time than they had to consolidate the achievement of their revolution by building a coherent and strong state" 39).

Apart from the two causes mentioned above, the tenth and final chapter introduced a third explanatory factor for the Empire's collapse, namely the nature of the experiment itself. The basic assumption underlying the Segu- Tukolor experiment--that Islam could be the basis for empirebuilding--was, according to oloruntimehin, false; no ideology could ever bring about large-scale political integration in the absence of a coherent political and social infra-structure ${ }^{40)}$. While up to the tenth chapter oloruntimehin's book was comparable to Adeleye's study of the Sokoto Caliphate--highlighting African resistance and vindicating the viability of a precolonial West African political unit--the overt rejection of the Tukolor experiment as irrealistic and not feasible at that time and place, gave the book an unexpected turn.

Oloruntimehin made the same point in an article published in Odu which dealt with the same subject of the anti-French coalition of different groups and states of West Africa, including the Tukolor Empire:

"A coalition, or united front, can achieve its objectives only if it is based on a solid infra-structure of identity, and integration of economic and political goals, as well as a technological development of the people involved" 41).

Here the implication was that hostility to a common enemy in itself was not a sufficient basis for creating and maintaining a solid coalition or integrated unit.

Why was oloruntimehin so explicit and emphatic in rejecting ideology-- 
religion, hostility to a common enuiy or, one might add, nationalism-as a sufficient basis for achieving large-scale economic and political integration? Why did he give so much stress to the economic, political and even technological infrastructure as the factor determining the failure or success of such a unity or coalition?

In view of the fact that both the article and the preface of the book dated from 1970--which wi.tnessed the end of the Nigerian Civil War-- the rash historiographer might be tempted to relate this preoccupation with the causes of collapse of large politicai entities or coalitions, as well as with the conditions for their success, to the experience of the Nigerian Civil wax which came very close to shattering the integrity of the Nigerian state. However, this interpretation is not born out by the facts. In an article entitled "The Anti- French Coalition of African States and Groups in the Western Sudan" Oloruntimehin indeed related the past to the preseit, but he did not refer to the sad present of a country just emerging from civil war:

"In its objective of fighting against imperialism the coalition can be regarded as a nineteenth century precursor of the presentday attempts of African states to unite in order to fight and achieve a decolonisation of the continent" 42).

Apparently he referred to the present task of achieving true decolonisation of the African continent through the formation of a strong and solid coalition of African states; a coalition which could only succeed--as the nineteenth century experiment analysed in oloruntimehin's work demonstrated-- "with co-oräinated educational, economic and technological developments which must proceed concurrently with political integration" 43). Oloruntimehin's work was not (yet) concerned with present failure, but with a hopeful future. In revealing the continuity of history it could provide a source us inspiration to the present: Oloruntimehin saw a continuity of effort at achieving African unity, which failed in the past, but could be crowned with succes in the present. His work indeed still helnnged to "the moment of optimism" 44).

\section{2: African Reaction to European Action: Cooperation}

- The missionary factor and the tuvis of mo tern Nigerian nationalism 
by resisting, others cooperated. And if resistance to European control was a popular theme of early Nigerian historiography, cooperation --particularly cooperation with those "pathfinders of imperiaIism", the missionaries--became at least as popular. Saburi O. Biobaku's book "The Egba and their Neighbours, 1842-1872" was the second book to be published by a Nigerian professional historian. It was published in 1957, and was a revised version of Biobaku's Ph. D. thesis which had been submitted to the University of London as early as 1951. The book dealt with:

"...the external relations of the Egba state from the time when the first missionary arrived at Abeokuta to the departure of Commander Glover from Lagos" 45),

that is to say with the

period of European presence on the West African coast up to (but not including) the era of direct British interference. Was this study of the Egba and their neighbours a study of African reaction to European action? This it was, even if it was not evident from the title; for the Egba's neighbours included the Ijebu, Ibadan, Dahomey and... Lagos which was occupied by the British in 1851. The first part of the book described the early history of the Egba until their migration to Abeokuta. The remaining part was, as Biobaku himself put it:

"...essentially a study of the reactions of indigenous peoples to outside events: the impact of the Atlantic slave trade; the return of kinsmen once carried away in slavery; the advent of missionary enterprise; the installation of official British influence and, later, power at Lagos; and the gropings towards the expansion of trade into the interior" 46).

As in the other works of early Nigerian historiography the effects of the European presence and African reactions to it was central to the book. Who were the Europeans present in Lagos and Yorubaland in the period 1842-1893? And who were the Africans whose reactions were under study here?

These Europeans were of course the British. They were represented first of all by the missionaries, who arrived in Abeokuta in the 1840s. To them the Egba town of Abeokuta became "the sunrise in the Tropics" 47), the hopeful centre from where commerce and christian civilisation would radiate into "the ark but fertile interior".

In the second place the British were reprosented by the consul in Lagos, whereas the British merchants did not fiqure as an indrpendent 
factor in Biobaku's book. As for the opposing party, the book was concerned mainly with the Egba and with Egba reaction, which was generally one of cooperation with the Europeans, in particular with the missionaries. These, regarding the Egba as the spear-head of civilising activities in Yorubaland, even saved it from annihilation by its attacking Dahomean neighbour through obtaining Bitish military support for the Egba. Abeokuta's expansionist policy after 1854 was, therefore, strongly supported by the missionaries. The British administration in Lagos, however, favoured the diffusion of British influence throughout the area--and not only in Abeokuta--and was inclined to take trade necessities as its guide. Hence a clash of interests between Consul and missionaries, between Lagos and the Egba became inevitable.

It must be obvious that the relations between the British inissionaries and Consuls figured prominently in the book. Yet, focussing upon the Egba, Biobaku was writing from an African perspective. A very specific perspective, one must admit, for the traditional. (Egba) ruling elite, which often opposed the missionaries and their converts (often immigrants from Sierra Leone or ex-captives and liberated slaves) received hardly any attention; nor did the Muslims and other opponents of Christianity. Biobaku did not only give undue attention to the "missionary party" among the Egba and the Yoruba in general, but even identified himself with their cause, for he regretted the death of Consul Foote,

"... who agreed with the missionaries that the Egba should be the spearhead of civilizing activities and that they should be strenghtened in order to become the instrument of British policy in the area" 48),

and his replacement by a Consul who had no pro- Egba sympathies: "Unfortunately Foote died... 49) (italics mine). Indeed the African side of Biobaku's story was the side of the Christian or missionary elite only.

The missionary factor and its product, the educated African elite formed one of the major themes of early Nigerian historiography, as will become evident from the discussion of the studies of J.F.A. Ajayi and E.A. Ayandele below. This tendency to overemphasize the importance of this elite came under violent attack in 1969, when 
E.A. Ayandele--who himself had published a major work on the missionary impact on modern Nigeria in 1966--sharply criticised the fact that:

"...historical writing on Nigerian has focussed its attention on the largely unaccepted Christian religion paraded by the parvenu aristocracy; on their aversion to the all-essential institution of slavery; on their ill-digested, alien-orientated political and constitutional aspirations; on their infinite hope in the triumph of literary education; in their cultural nexus with the non-Nigerian world" 50).

Ayondele implied that the Nigerian historians--themselves members of the twentieth-century educated elite that lived through a golden era in the period prior to and following independence--gave an anachronistic interpretation of the importance of the nineteenth-century educated elite, which was "numerically insignificant" 51) and alien:

"It is clear that our selection of individual members of this class for the honorifics "eminent" and "Nigerian" is based more on values and aspirations derived from the modernized sector of the country's present day life than on the opinion of the masses" 52).

Was Biobaku reading the importance of the social elite to which he himself belonged back into the past?

Here we are not concerned with giving final judgements; significant to this essay is the shift in focus that took place in Nigerian historiography between 1957 and 1969, and its implications for the historical studies written in this period. How the different perspectives of S.O. Biobaku and E.A. Ayandele could lead to diametrically opposed interpretations can be illustrated by their completeiy different views of the events in Abeokuta in the period 1898-1914. For Biobaku Abeokuta was a success story. Even if "Lagos won the contest with Abeokuta as the centre of British influence", the Egba remained independent "when all territories around had been absorbed into the Lagos Protectorate System". Biobaku called the period 1898 to 1914 "a unique experiment in self-rule" and ascribed this success "to the early stand against encroachment which the Egba, aided by the C.M.S. (...) and later by the Sierra Leone immigrants, had made against the expansionist policies of both Freeman and Glover" 53). Ayandele had an altogether different view of this period of "independence": He argued that from the perspective of the traditional Egba authorities and the common people, the coalition between the African educated elite--largely consisting of sierra Leoneans--and the missionaries did actually represint iritish interforence and control. Even if this was not true according to the letter of the 
law, this was the experience of the people. At the same time the British administration understood that Abeokuta did not require their direct and overt interference, since the resistance of the traditional authorities was broken, or soon to be broken for them by the missionary party:

"In 1891 the protestant party in Abeokuta was as strong as to make the independence of the traditional authorities a farce" For Ayandele then, the period 1898 to 1914 was for the Egba one of "sham-independence".

Another pioneer-historian was J.F.A. Ajayi, at present Chancellor of the University of Lagos. Even more than S.O. Biobaku Ajayi wrote about African reaction to the activities of one specific European agency, the missionaries. His major work "Christian missions in Nigeria, 1841-1891- the making of a New Elite", published in 1965, was a revised version of his Ph.D. thesis submitted to the University of London in 1958. It is evident from the book's title that the period under study was again the transitional period between "informai" and "formal" Empire. Again, the geographical framework of the book was Southern Nigeria, although it would be more correct to say those regions of present-day Nigeria where the Church Missionary Society had established itself by the 1840s. Though dealing with "the missionary factor" the book's perspective was African in the sense that it highlighted the part played by Africans in the Church set up by the missionaries; that is to say, it was a study of the more or less educated missionary "elite".

Before we turn to a discussion of the major themes of Ajayi's work, we need to modify a statement made above, that the early Nigerian historiography consisted of studies of political history only. Ajayi's study is not purely political history ${ }^{55)}$ : The first five chapters of "Christian missions" deal with the arrival of the missionaries, their establishment on the coast, in the interior (Yorubaland) and in the Niger Delta. Of the five missionary societies the C.M.S., particularly in its relations with Consuls, traders and traditional tribal authorities on the coast, received most attention. If this might still be called "political" or "evenemential" history, the next chapter called "Civilization around the Mission House" 
could not. Dealing with the social impact of education, building, printing, health service, etc. it was social history rather than political history, while the last three chapters, analysing Africa's changing image in Europe, and the roots of Nigerian nationalism, were actually an exercise in intellectual history or the history of ideas. If there was any Nigerian historian who believed in the continuity of the pre-colonial past and the post-independence present, it was J.F.A. Ajayi. He devoted two articles to this "trans-continuity" of African history, namely the articles entitled "Colonialism: An Episode in African History" 56) and "The Continuity of African institutions under colonialism" 57); but in fact this same belief in the continuity was basic to all his academic work ${ }^{58)}$, in particular to his interpretation of the roots of modern Nigerian nationalism 59) which has made him famous.

His book about the Christian missions in Nigeria had two closely related major themes, or theses:

First, Ajayi argued that the most important effect of missionary activity in Nigeria was not the implanting of Christianity or a moral regeneration of the people but the fact that it produced a new "Nigerian" middle class on the lines of Europe and America; for western education which the missionaries provided created for their converts opportunities for rapid economic advancement.

The 1870 s--as we have seen above ${ }^{60)}$--were the golden age of this incipient middle class, but with the changing attitudes in Europe the policy of devolving as much work as possible upon an African agency was reversed. The ousting of the first Afxican bishop S.A. Crowther showed, as Ajayi put it:

"...that the transmutation of Europeans from guides to rulers was complete in the Church as it was becoming complete in the administration of the country, and that the earlier policy of encouraging the growth of an African middle class was completely overturned" 61).

But by then the missionaries had trained a group of Nigerians who had accepted their ideas and who hoped to carry them out; this "new midale class" refused to be brushed aside.

It was to this period of Afxican protest against the increasingly racist opinions and attitudes of the Europeans that Ajayi traced the roots of Nigerian nationalism--the second theme of Ajayi's work and of early Nigerian historiography in general. Where were the nineteenth-century roots of Nigerian nationalism to be found? 
Nevertheless the differences may be even more significant. The focus of Ayandele's work was considerably wider than that of "Christian missions", or rather, it had a triple focus: The first part was a political and social analysis of "African" reaction to the establishment of missionaries in the coastal citystates and in the interior of Yorubaland. Which "African" reaction? That of the local authorities to the political and social changes effected by missionary activities. Central to this part of the book was Ayandele's contention that the missionaries were the pathfinders of British imperialism, staging as it were a silent coup:

"From the start (...) missionary propaganda in Nigeria was not just a religious invasion. In effect it was associated with a political invasion as well. In the background was the secular arm of Britain to be involved when practicable". 69)

When in 1855 old Town was destroyed by British naval power called in by the missionary party on the spot, this was according to Ayandele: "...one of the first examples of military action by the British largely at the behest of the missionaries, designed to coerce traditional conservatives who resisted the penetration of European moral and Christian codes, even though the Africans in this case had not in fact committed themselves by treaty to such a course" 70).

The same thing happened elsewhere on the coast and in the interior, for "the missionary element was present in all the major military expeditions of the decade under consideration" 71), i.e. 1892-1902, as Ayandele amply illustrated.

Only in Northern Nigeria the missionaries allegedly failed to convince "the secular arm to unsheath the sword on behalf of the Cross against the Crescent", for several reasons outlined in his fourth chapter. Chapter five analysed the pattern of response to missionary appeal of the major ethnic groups of Southern Nigeria, such as the Yoruba, Ibo, Ondo, Edo, etc. Here the masses came into the picture, though the analysis was short and superficial, immediately shifting to the worsening relations between missionaries and administrators, and between local authorities and converts.

In 1969, three years after the publication of his book, in an article called "How truly Nigerian is our Nigerian Historiography?", Ayandele sharply criticised the tendency of Nigerian historians to write the history of the cream of society rather than that of the people; 
and to focus upon the traditional patricians and the "numerically insignificant educated elite" only--as has been discussed above ${ }^{72}$ ). This implied a negative evaluation of the studies--particularly the perspective of the studies--of S.O. Biobaku and J.F.A. Ajayi. But what about his own study published in 1966 ?

In the "Note of the general editor" 73) K.O. Dike assured the reader that the works of Ajayi and Ayandele were "manifestly distinct in content, in emphasis, in scope and in perspective":

"Dr. Ayandele concentrates on the political and social history of Nigeria from 1842 to 1914 through the mirror of missionary propaganda, as seen by the peoples themselves".

Who are "the peoples themselves" to whom Dike referred, one may ask, and where do they feature in Ayandele's book? Are they the masses which should be the stuff of history, as he argued in 1969? Are they the different strata of society, or did Dike refer to the different ethnic groups of Nigerian society?

When we return to our point of departure, which was the guestion of the focus of Ayandele's fifth chapter, it is evident that this focus did not centre upon the lower strata of society, but upon various ethnic groups whose response to missionary activity was to some extent at least discussed. The shift of focus from social elites to broader strata of the population, advocated by Ayandele in 1969, had not taken place in 1966.

The second part of Ayandele's book (chapters five to eight) was essentially an exercise in the history of ideas. It centred upon the roots of nationalism which Ayandele, like Ajayi, traced to the missionary elites. In missionary archives and official records, he argued:

"The causal relationship between missionary activity and the rise of nationalism are glaringly manifest" 742 .

Even if Ayandele traced the roots of nationalism to one and the same social elite, within this group he distinguished two movements of thought which--following each other in time--provided scope to the expression of nationalist sentiments: 1. First, Ethiopianism 75), the movement of African churches for autonomy within or independence from the metropolitan churches. 2. Secondly, the movement of cultural nationalism, essentially a revolutionary repudiation of European culture in favour of African cultural values, manifesting itself in the wearing of African clothes, taking African names, studying traditional religion and writing African history ${ }^{76)}$. 
Again one must examine Ayandele's criteria for calling the "Ethiopianists" and "cultural nationalists" "Nigerian nationalists". Ayandele admitted that he used the terms "Nigerian" and nationalism" 'rather loosely", but --he added-- "not inappropriately 77). He argued that both Ethiopianists and cultural nationalists identified Christianity with Western European political organisation ${ }^{78)}$, as Ajayi did, implying that they thought in terms of a future nation-state. As for calling them Nigerian nationalists, Ayandele contended that in spite of the fact that there was no Nigeria, administratively spoken, until 1914:

"...nevertheless the idea of the territorial boundaries of the future Nigeria was vaguely visualized by 1898, when a railway to Kano was being advocated in the newspapers" 79).

Also Ayandele considered their nationalism more Nigerian than "African, Negro or Yoruba", for:

"...while cosmopolitan in their outlook they concentrated their efforts on events in what became Nigeria",

and although they

"...were mainly educated Africans with origins in Yorubaland, they spoke on the behalf of the peoples of Nigeria" 80).

Ayandele recognised that Nigerian Ethiopianism was rather pacifist 812 and that none of the early nationalists desired immediate political independence. Nevertheless he attributed to them a political inclination, which made them look upon the churches for administrative and political apprenticeship, at a time when distinctly political antagonism against the British administration was not yet feasibie ${ }^{82)}$. The crux of the argument was that the early "Nationalists" in struggling for independence and autonomy in Church affairs clearly visualised future political independence. The idea of a self-governing, self-supporting and self-propagating Church for them:

"...contained the principle of national independence in Church government, a principle that could be logically employed for the indigenization of Christianity and declaration of political independence" 83).

On the basis of these arguments Ayandele was convinced that:

"The establishment of the Native Pastorate in Lagos marked the beginnings of Nigeria to independence, under the leadership of educated Africans" 84).

Yet, even if he was convinced of this himself, he did not demonstrate convincingly, I feel, whether the educated African elite involved 
shared this conviction as well.

The third part of Ayandele's book dealt with the educational aspects of missionary activities. Again his perspective was not "truly African", for the analysis focussed as much upon the relations between the missionaries and the administration, as upon "the peoples themselves", i.e. the various ethnic groups.

In the concluding chapter called "Missionary impact on society" Ayandele more or less formulated his conclusions. The contradictions which these contained would not have detained us here, if they had not pointed to different--although not contradictory--commitments of the author.

Throughout the book Ayandele highlighted the enormous impact of the missionaries on Nigerian societies: They were the pathfinders of imperialism, often responsible for the "opening up" of the interior by British military expeditions. It was missionary education and Christianity that gave rise to the first stirrings of "Nigerian nationalism". Therefore it is surprising that Ayandele minimalised missionary impact on society in the final chapter. He minimalised its disruptive character since:

"After all, ideas do not make revolution" 85), and since after all,

"The administration brought about a social upheaval greater than the missions had been able to do in precolonial times" Ayandele even warned that the intrinsic spiritual and cultural conquest of missionary propaganda should not be overemphasised ${ }^{872}$. Also it is baffling that after having explained throughout the first section of the book that the missionaries could and actually did cail in the secular arm "to unsheath the sword on behalf of the Cross" 88), and that maxims and sevenpounders often followed the missionary trail 89), Ayandele concluded with criticising the British administration's anti- Christian and anti-missionary policy in the North:

"Unlike Southern Nigeria, the people were not allowed a choice of their own, but the officials assumed that the people did not need Christianity" 90).

Summarizing one may say that Ayandele's denial of the revolutionary value of ideas was in contrast with his own analysis of the roots of Nigerian nationalism; while his minimalisation of the missionary impact was in contrast to the ten preceeding chapters of his book. 
How can one account for Ayandele's ambivalent last chapter, and at times contradictory statements?

One might point to the author's double commitment:

First, his commitment to nationalism, manifest in his analysis of the roots of Nigerian nationalism and his preoccupation with continuity. Secondly, his commitment to Christianity, which became very clear at the last page of the book ${ }^{91}$ ).

Ironically, this double commitment and the ambivalence to which it --at times--gave rise are, I feel, the most convincing evidence for the continuity between the nineteenth-century missionary elite and the nationalist educated elite of the early sixties. 
Notes to Chapter Five

1. Of course there are exceptions confirming this rule. In the journal Tarikh, written for an audience of secondary school students and undergraduates and their teachers, there are many articles on non- Nigerian African history. E.g. on Tanzania/Tanganyika in Tarikh III, 3, 1970 and Lybia (Folayan, 1972, 1973, 1974). Oloruntimehin (see above.pp. 60-2) studied the history of former French West Africa.

2. Dike (1956), p. 225. See also Biobaku (1957) and Akintoye (1975), p. 119. Akintoye (1971) mentioned 19 local historians among his sources.

3. Biobaku (1957) p. 117. He gives a list of the places visited, the people interviewed and the dates on which the interviews took place. Apparently the "knowledgable" people who were interviewed were mainly members of the traditional ruling elite; of the colonial administration--both traditional and modern (i.e. educated element); local historians and teachers.

4. Wrigley (1971), Hodgkin (1976) and Ochieng (1974) offer the same interpretation. See also Conclusions of this essay.

5. see. e.g. works of B.G. Martin, J.O. Hunwick Abdullahi Smith, M. Last a.o.

6. Ayandele (1969), Coleman (1958), pp. 327-8.

7. quoted in Fyfe (1976), p. 4.

8. 1956.

9. Dike (1956), p. 13.

10. idem, p. 4.

11.idem, p. 11. Compare this statement with the focus of Akinjogbin (1967), who examined the internal evolution during these 400 years.

12.Dike (1956), p. 34: the House- system which --as Dike put it: "in its full development (...) became at once a cooperative trading-unit and a local government institution based on kinship, but on common interests and economic necessities".

13.idem, p. 8 .

14.idem, p. 114 .

15.Dike in "Eminent Nigerians.." (1960), p. 9.

16. Eminent IJigerians.. (1960), p. 70.

17.idem, p. 71 .

18.idem, p. 15 .

19. "Eminent Nigerians.." (1960), p. 16.

20. idem, p. 24.

21. J.C. Anene and S.O. Biobaku in "Eminent Nigerians.." (1960), resp. p. 25 and pp. $26,29$.

22. Ayandele (1969), pp. 26 and 27.

23. See text on book cover: "...they are the forebears of the people who are regaining independence throughout west Africa".

24. Ikime (1968), p. 11.

25. Tamuno (1965), p. 276. 
26. Ikime (1968), p. 136.

27. idem.

28. idem.

29. Ayandele (1971), p. XVI. Ayandele's book was a revised version of his $\mathrm{Ph}$. D. thesis submitted to the University of Ibadan in 1967 under the title "The Overthrow of the Sokoto Caliphate".

30. Adeleye (1971), p. 113.

31. idem, p. 286.

32. idem, p. 314.

33. idem, 311.

34. idem, p. 284.

35. See Adeleye 1968; 1970; 1972; and Adeleye and Mukoshy (1966). At present it is actually impossible to speak about Northern Nigeria since the "Northern Region" existing during the colonial period now consists of ten states. See maps page 79 .

36. Oloruntimehin (1970).

37. See Oloruntimehin (1968), (1968a), (1969) and (1971).

38. Oloruntimehin (1972), p. 315.

39. idem, p. XIV.

40. idem, p. 324 and p. 328.

41. Oloruntimehin (1970), p. 21.

42. idem, p. 19.

43. idem, p. 21.

44. See Hopkins (1976) p. 131; also Conclusions of this essay.

45. Biobaku (1957), p. v.

46. idem.

47. idem, p. 32 .

48. idem, p. 67.

49. idem.

50. Ayandele (1969), p. 25.

51. idem, p. 24.

52. idem, p. 25.

53. Biobaku (1957), p. 98.

54. Ayandele (1966), p. 44.

55. "Political history" is here used in the sense of what the historians of the French "Annales"-group have called "histoire évenementielle" in contrast to "histoire conjoncturelle" or "histoire structurelle". See e.g. Glénisson (1965), pp. LVIII and LIX.

56. Ajayi (1969).

57. Ajayi (1968a).

58. With the exception of Ajayi and Smith (1964). 
59. Ajayi (1961).

60. See above p. 8 .

61. Ajayi (1965), p. 269.

62. Ajayi (1961), p. 196.

63. idem, p. 197.

64. idem, p. 201.

65. idem, p. 196.

66. idem, p. 203.

67. Ajayi (1965), p. 271.

68. idem, p. 73.

69. Ayandele (1966), p. 8.

70. idem, p. 24 .

71. idem, p. 113 .

72. See this chapter, pp. 64-65 and Ayandele (1969), p. 24.

73. Ayandele (1966), p. xx.

74. idem, p. 176.

75. idem, p. 178.

76. idem, p. 259. Ayandele called historiography "probably the greatest achievement of cultural nationalism". He referred to historians such as S. Johnson, O. Payne, discussed above (pp. 8-10).

77. idem, p. 175, note 1.

78. idem, p. 179.

79. idem, p. 175 , note 1 .

80. idem.

81. idem, p. 202.

82. idem, p. 203.

83. idem, p. 181.

84. idem, p. 191.

85. idem, p. 331.

86. idem, p. 334.

87. Ayandele (1966), p. 340.

88. idem, p. 136.

89. idem, p. 135.

90. idem, p. 152.

91. idem, p. 345. 


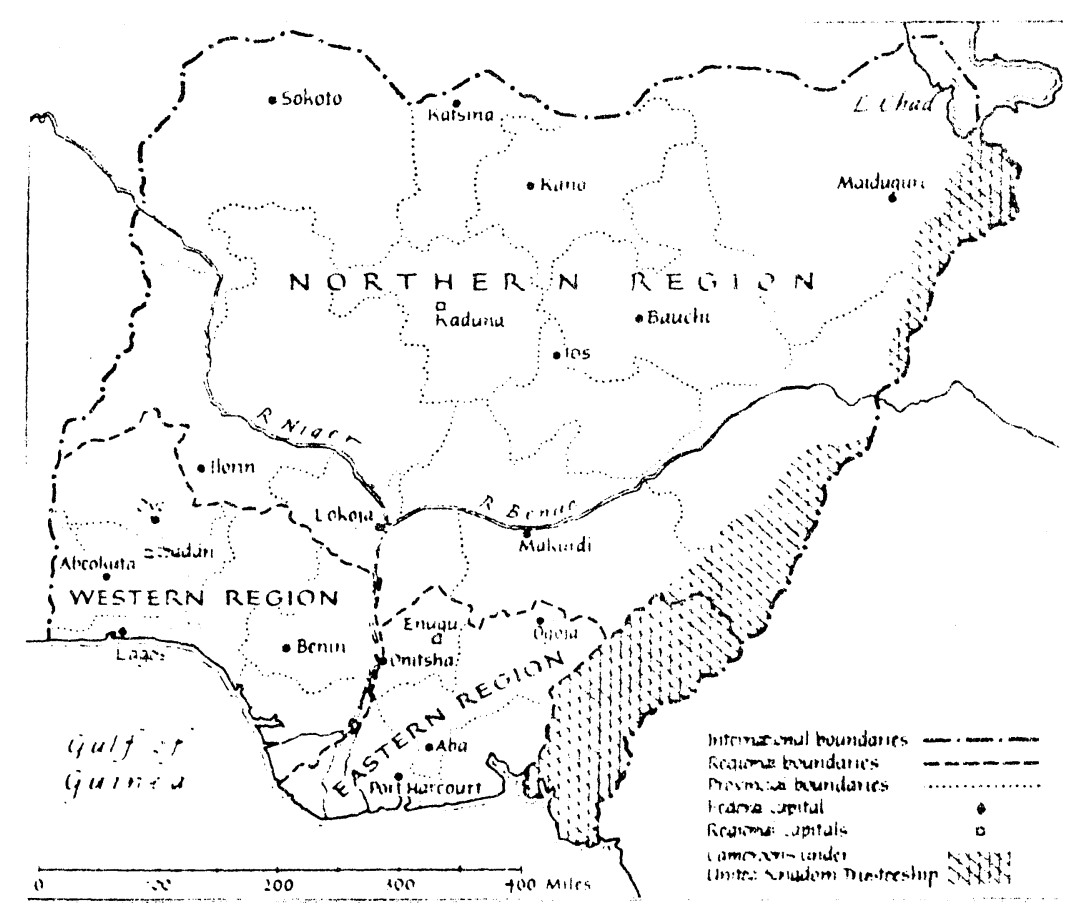

Nigeria before independence

from T.N.Tamuno (1971), p. 1.

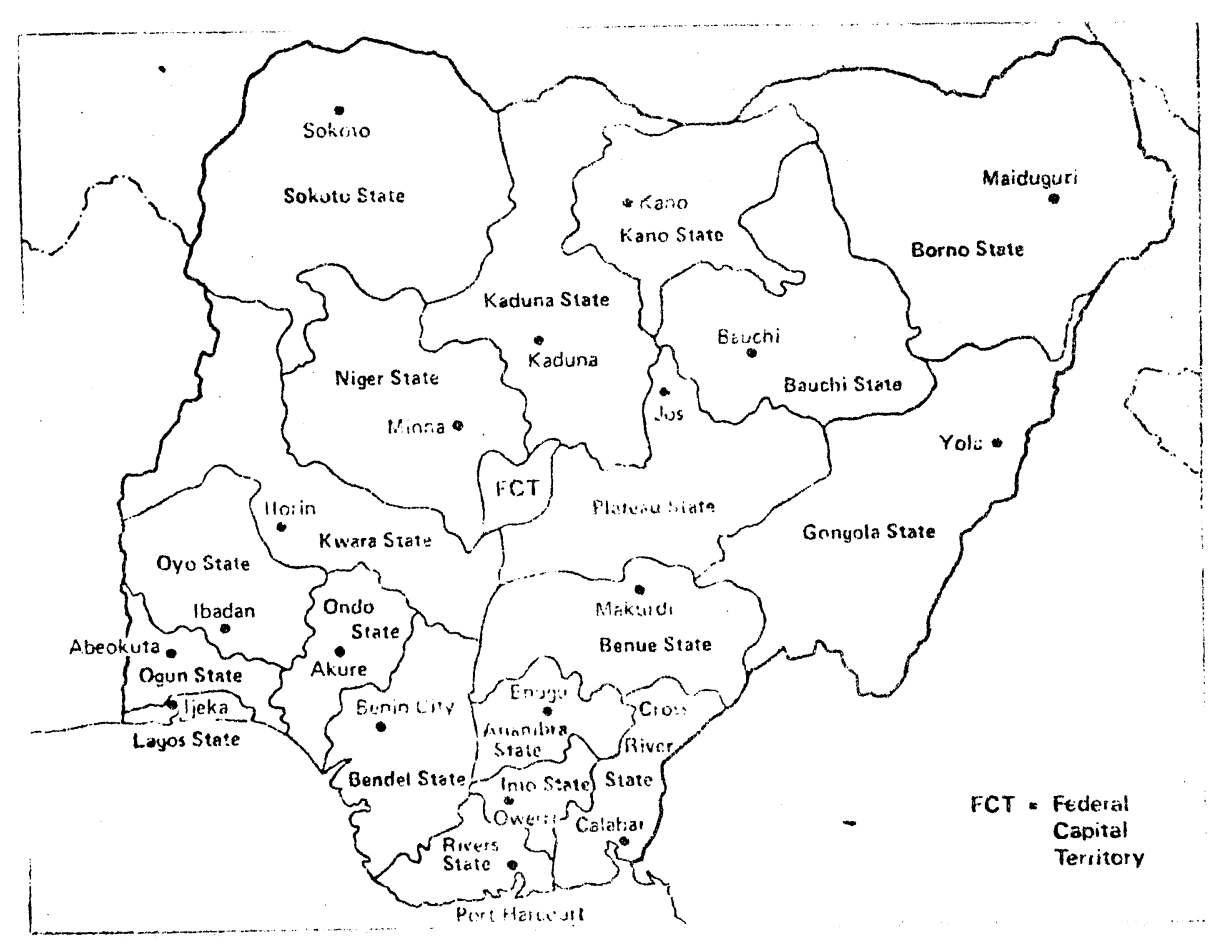

The nineteen states of present-day Nigeria as formulated by the administration of President Murtala Mohammed and carried out under the current President olusegun Obasanjo. From Arnold, G. (1977), Appendix 4. 
CHAPTER SIX

Nigerian Historians and the Early Pre-Colonial Past:

-the virility and viability of African political systems-

Africa has often been presented as a contingent where highly fragmented small-scale societies--centralized or uncentralized-were the most common form of political organisation- or disorganization. The myth that nothing of much importance went on in Africa prior to the arrival of the Europeans has long been common coin, and was not invented by modern historians trying to bring out the revolutionary nature of their own, modernised point of view. When African historians began to publish their own research, they set out to correct this false image of a static, chaotic and primitive Africa and turned to the pre-colonial past to disprove this myth. Most of the first Nigerian academic historians turned to the "resisters" and early "nationalists" of the Scramble era. Others, in particular some of the "second generation" of professional historians--more often than not trained in Nigeria itselr-- turned to the early pre-colonial past to disprove this myth.

First, they pointed at the great West African Empires of the past (Ghana, Mali, Songhay, Benin, etc.) to demonstrate African capability to create large and well organised political units, in which art flourished and trade thrived.

Secondly, they turned to the study of smaller states and ethnic groups, to prove that a small scale did not necessarily imply inferiority; and that decentralisation did not mean chaos. It was the African historians themselves who related their historiography to the need for a rehabilitation of the African past, and to the quest for oxigins and identity of the new state. They themselves coined the term "History for Self-government." ${ }^{1)}$, convinced as they were of the relevance of historical research to the present and to the future of the nation. Their emphasis on great political achievements in the African past, and the viability of the traditional political systems featured--implicitly or explicitly--in all studies 
dealing with African resistance to European penetration; it figured even more prominently in the historical studies of the earlier past. The bulk of this historiography of the pre nineteenth-century past was published after 1966, the major exception being the small cooperative study by J.F.A. Ajayi and R. Smith, entitled "Yoruba warfare in the Nineteenth Century" (1960), which will be discussed below. A transition between the first Nigerian historians and those discussed in this chapter was formed not by this work, however, but by I.A. Akinjogbin's "Dahomey and its Neighbours, 1708-1818", published in 1967. 2)

Though exceptional in the fact that it dealt with a relatively early period it was again a study of African reaction to the European presence. Akinjogbin himself presented his book as a study which attempted "to trace with the aid of hitherto unused documents the eighteenth century political developments in Dahomey..." and set out to account for the fact that Dahomey in the nineteenth-century was "an oasis of internal order and sound administration in a sea of surrounding chaos". 3)

It was exceptional as well, one might add, in its focus upon an area outside modern Nigeria, but one should take into account that the history of the area under study--the southern third of the modern republic of Benin, which until two years ago was called Dahomey-was intricately entangled with that of its Yoruba neighbours in present-day Nigeria who have been the subject of other studies by Akinjogbin.

With the first Nigerian historians Akinjogbin shared a belief in the (trans-) continuity of the pre-colonial and post-independence era, and hence in the relevance of his study to the present predicament of the state:

"With the passing of the colonial era and the re-emergence of African states, whose relation with the outside world is almost exactly similar to those of their predecessors of the eighteenth century, such a study as this should have more than academic interest". 4).

Akinjogbin also shared with them an emphasis on the disruptive effects of the European presence, particularly the slave trade, ${ }^{5}$ ) and a preoccupation with the rehabilitation of the African past, as was evident from the way in which he concluded a discussion of 
the political stability of the Yoxuba- Aja peoples by the beginning of the sixteenth-century:

"Stability need not create and must not be confused with static conditions. (...) It must therefore not be imagined that static conditions prevailed from the moment this stability was created until the Europeans came to destroy the old ways".6)

"Dahomey and its neighbours" was essentially the story of how the European presence on the coast and their slave trading activities gave rise to new political formations on the African coast, with special attention to the part that Africans played in this process. The story is this: In approximately 1700 a group of people seceded from the coastal Aja communities and founded a new state inland, called Dahomey. In 1724, however, Dahomey, led by its king Agaja invaded the coastal area, and although the conquest was successful, in 1730 Agaja was forced to submit, politically, to the neighbouring Yoruba kingdom of oyo and, economically, to the Europeans who compelled him to carry on the slave trade. ${ }^{7)}$ The rest of the period (until 1818) was one of progressive economic decline and weakening of political bonds for Agaja's kingdom.

How aid Dahomey in spite of this becone the strong, incorrigible slave trading kingdom that it became in the nineteenth century? First, Akinjogbin argued, because it was forced to depend completely on the slave trade for its economic well-being. Secondly, because the administrative principle of having a king as effective central authority became firmly established during the period of Oyo overrule. Akinjogbin emphasized the disruptive effects of the slave trade, but why did he fail to analyse the motives for African resistance to the slave trade; particularly the motives of the founders of Dahomey, who allegedly seceded in order to be "beyond the immediate reach of the slave-raiders and slave trade influences"? ${ }^{8)}$ By calling the resisters "the responsible, the discerning natives" and "a little band of highly principled and far-seeing individuals"9) he did not give any evidence but a judgement of value.

There were other flaws in Akinjogbin's argument. We have seen that Akinjogbin set out to look for the eighteenth-century basis of Dahomey's stability in the nineteenth-century. This intention resulted in a positive evaluation of everything that strenghtened the political unity of Dahomey and a negative one of every factor 
endangering the survival of the state. The effective centralisation introduced by the founders of Dahomey was valued positively throughout the book, even if the means by which it was maintained were manifestly tyrannical and caused a decline of the population ${ }^{10}$. Taking nineteenth-century success as the guiding criterion for analysing and evaluating eighteenth-century history cannot but be called an anachronistic approach to the past. Only this can account for Akinjogbin's judgement of Agaja, whose thirty-two year reign ended in failure--as is evident from the book-but who was nevertheless praised by Akinjogbin as "one of the greates kings of Dahomey, and one of the great leaders and state builders of history", for "he left one intangible but important legacy: to the end he maintained the principle of absolute authority of the king within Dahomey unimpaired" ${ }^{11)}$.

The negative evaluation of the European role in the economic and political development of Dahomey during the eighteenth century is not surprising and is justified, I trust. However, the positive evaluation of the role of Dahomey's Yoruba neighbour Oyo, is baffling. After all oyo destroyed the coastal towns time and again, and forced Dahomey to recognize its sovereignty and to pay annual tribute. Here Akinjogbin betrayed another bias, namely one in favour of the Yoruba, (Oyo) :

"As was to be expected they played a very positive role both in the political and economic development of Dahomey, though only the unsavoury aspects of their century of imperial rule over Dahomey have usually been remembered by the Dahomeans" 13).

Why was Oyo's interference in Dahomey's affairs regarded as constructive? According to Akinjogbin Oyo's domination after 1748 gave Dahomey the opportunity to reconstruct the foundations of the internal administration, and to copy some of Oyo's political institutions, which were to serve them well in the next century. Again Akinjogbin read the nineteenthcentury present back into the eighteenth-century past. His preoccupation with one of the large and strong political units of Africa's past was not untypical of early Nigerian historiography as a whole.

Though most of the works of the period 1955- 1965 dealt with "European action and African reaction", "Yoruba Warfare in the nineteenth century" 
by J.F.A. Ajayi and R. Smith, published as early as 1960 was an exception to this rule, pointing to future developments. Though a slim volume consisting of an introduction and two essays, it was a pioneer study of "truly African" history, in this sense that it examined a fragment of African history which was not influenced by, nor a reaction to European activities in Africa. Admittedly, the period under study (1820-1893, and in particular the period of the Ijayi War: 1860-5) was again the period leading up to the Scramble and European penetration inland; but the main focus of the work was the internal political development of Yorubaland, the Europeans coming on the scene only in the last stage of the wars under study, at the request of the Africans involved. The authors set great store by this concentration upon the internal dynamics of African political development, i.c. 19th century Yorobaland. They explicitly dismissed the idea that the Yoruba wars of the nineteenth century were caused by the Atlantic slave trade (i.e. an external factor) or were simply one example of the internecine conflicts which allegedly had been the normal state of affairs in pre-colonial Africa. It was the intention of the authors to disprove the myth of the static character of African political institutions and mutual relations, and to rehabilitate these. (E.g. J.F.A. Ajayi gave the fraticidal war, which the decline of the Oyo Empire brought in its wake and which lasted more than seventy years, the very respectable name of "a constitutional conflict" 14), The authors described the wars as an internal affair, namely as struggles for power among the states, which tried to fill the vacuum created when the Old Oyo Empire collapsed.

This "all-African" focus of "Yoruba Warfare" was a new development in Nigerian historiography. The sources upon which it was based however were mainly "traditional", in the sense that the bulk of them was made up by European sources (travel reports, correspondence of the missionaries present in the different towns, and a report on the Egba army written by Captain Jones of the West Indian Regiment in 1861). "Internal" i.e. African evidence was used only to a small extent: e.g. the written history of the Yoruba by S. Johnson, who collected and recorded oral eye-witness accounts as early as ten years after the event; and orally transmitted songs and praise verses. "Yoruba Warfare" was an eye-opener. It was a sketch rather than a full-scale study of the Yoruba wars. It opened a line of research 
which was continued by others such as Kola Folayan 15), Bolanle Awe 16) and S.A. Akintoye.

The first major study which continued this line of research was S.A. Akintoye's "Revolution and Power Politics in Yorubaland, 1840-1893 - Ibandan expansion and the rise of Ekitiparapo". Although the original thesis was submitted to the University of Ibadan in 1960, the book was published in 1971. Essentially the book had the same theme as "Yoruba Warfare":

"... the power revolution among the Yoruba, its nature and consequences, and the nature and sociology of Yoruba Warfare in that century" 17). (i.e. the nineteenth century)

Both studies demonstrated a common purpose or commitment to reveal the 'internal' factors of change in African history. Without denying that foreign formative forces were intertwined with internal forces, Akintoye argued:
"It is now generally accepted that in origin the movement was essentially concerned with new attempts at state formation and the institution of new centres of power and that the explanation for it can only be found in factors indigenous to the Yoruba community itself" 18).

Akintoye's book was much more detailed than "Yoruba Warfare" and was based upon more, and more varied sources. Two major themes can be distinguished: One was the rise and expansion of Ibadan, which by 1863 had become the most powerful successor-state to the Oyo Empire: The nature of its warfare, the causes of its success, and the abuses of power which bred resistance among the other Yoruba states. The second theme was the impact of Ibadan's expansion on the Norhteastern part of Yorubaland, and the reaction of its inhabitants, the Ekiti, Ijesa, Akolo and Igbomina Yoruba subgroups, which founded a confederacy called Ekitiparapo in 1878 to face Ibadan's imperialism. It was the history of this confederation of the minutely fragmented communties of Northeastern Yoruba land that was traced in this book: How it put up resistance against Ibadan's exploitation; how it succeeded -- at least temporarily -- in isolating Ibadan both politically and economically; finally, how the restoration of peace in 1886 signified the end of the Ekitiparapo since it ended the necessity for further cooperation. 
What was according to Akintoye the importance of these political events in nineteenth-century Yorubaland? And what did he think was the relevance of this study to twentienth-century Nigerians? The rise of Ibadan was, Akintoye argued, one of the most important developments in the history of the Yoruba first of all since it saved most of Yorubaland from conquest by the Muslim aggressors from the North, the Fulani. Secondly, since the wars to which the rise of Ibadan gave rise created the occasion for repeated British interference in Yoruba affairs. Thirdly, since these wars resulted in a considerable intermixing of the Yorubas, and in demographic changes which came to determine the population map of modern Southern Nigeria. Fourthly, and now we come to a reason of a quite different nature, since:

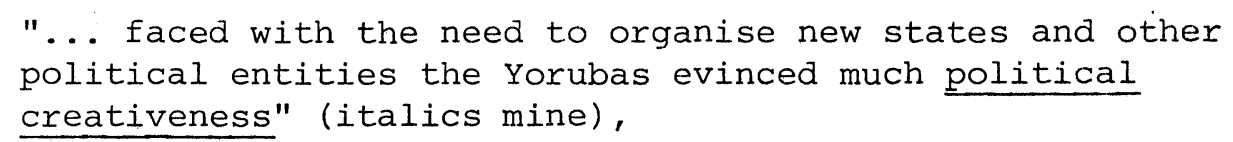
political entities the Yorubas evinced much political creativeness" (italics mine),

namely,

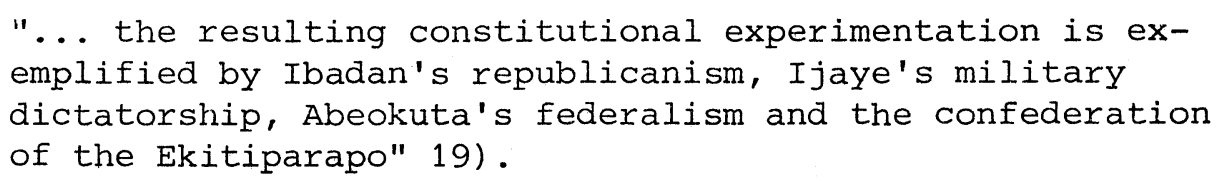

Also the cases of the Ibadan Empire and the Ekitiparapo alledgely demonstrated that often these political units commanded loyalties far beyond the outlines of the petty kingdoms or even sub-ethnic divisions.

Like "Yoruba Warfare", this study of the pre-colonial African past attempted to demonstrate the virility, creativeness and dynamism of African political systems, and African capacity to create large political entities. This then was its relevance to twentieth century Nigerians.

Akintoye's study demonstrates as well that historiography could indeed be relevant to the present without becoming anachronistic.

E.J. Alagoa was another historian who criticised the tendency to give primacy to external factors of change over the internal. ${ }^{20}$ ) At the same time he took Africanists to task for using almost exclusively "external", i.e. European sources at the expense of internal source material, and for an overemphasis on the later period for which a comparatively large body of records had been accumulated by British traders, administrators and missionaries. In itself 
this criticism was neither new nor revolutionary. The revolutionary element was that Alagoa in his own research deliberately steered away from the tendencies he criticised. His work, particularly "A History of the Niger Delta: an historical interpretation of Ojo oral tradition" (1972) is indicative of some of the changes that had taken place in Nigerian historiography since the late fifties.

In a sense Alagoa realized the programme outlined in the sixties, which until then had been brought into practice only partially. The first Nigerian historians had 'manifested' their conviction and delight that African historical traditions had been kept alive throughout the colonial period, and that it was a valuable and valid historical source. They had gone out of their way to vindicate the value of this "internal" oral material in the face of sceptic Eurpeans and Americans. Yet, most of the early historians --as we have seen in Chaptex Five-based their work on local and metropolitan archives, using orai eyewitness accounts and traditions recorded by local historians only to add, revise or differentiate some aspects. The first African historians had "manifested" their purpose of writing history that would be relevant to the new nation; they "manifested" their commitment to rehabilitating the African by highighting the African side of the story. However they focussed upon African reaction rather than on African initiative.

The first African historians had put forward that Africa reaily had a history--a great and glorius history even-- before the Europeans arrived. Yet, they themselves concentrated upon the period of European presence in Africa.

Finally, African historians had denounced the Euro-centrism of European Africanists, but they themselves set out to trace the history of large political units, corresponding closely to the European pattern at the expense of the small-scale societies which formed the subject of Alagoa's study. 21 )

Alagoa's research did focus upon African history prior to the European presence in, and domination of Africa. As early as 1964 his study "The Small Brave City-State: A History of Nembe- Brass in the Niger Delta"-- dealing with the period 1450-1936 -- had five of its eight chapters devoted to the period prior to the nineteenth century. Even if the account of African reaction to European penetration in the last chapters of the book was in no way exceptional, 
the extent to which the pre-nineteenth centyry past featured in the book, and the extent to which it was based on oral traditions wás exceptional and pointed at a more general trend in Nigerian historiography as is evident from Afigbo (1971-1972) and Asiwaju (1976a).

Alagoa's second work, published in 1972, which attempted to reconstruct the early history of the Ijo people, continued the same line. This work entitled "A History of the Niger Delta: an interpretation of Ijo oral tradition" was based almost exclusively on systematically collected internal sources, taking in the whole field of Ijo oral traditions from the time covered by the traditions of origin until the nineteenth century.

Compared to earlier works of Nigerian historiography it represented a change of focus, time- scope and source material; a change in the concept of "truly African" history, one might say, here defined as pre-colonial history interpreted in terms of internal factors of change, and reconstructed from internal oral sources.

The revolutionary aspect of Alagoa's work should not be exaggerated, however. His work did not come as a bolt from the blue, but must be considered against the background of a steadily increasing use of oral traditions throughout the first decade of professional Nigerian historiography. The collection of oral traditions in the field was part and parcel of each Ibadan Ph. D. thesis right from the beginning in the early sixties, even if the oral evidence collected usually referred to a much later period than the one with which Alagoa was concerned. ${ }^{22)}$

Alagoa set the example for other historians in yet another way, namely, in his way of presenting and referring to his oral sources, for he indicated not only the date and place of the collection of his evidence, but also referred to sound archives where tapes and transcripts could be consulted. One may regret the absence of explicit references to these tapes in the text, but all the same his system of reference was a great improvement upon earlier Nigerian historical studies, and an important step towards making historical research based on oral traditions verifiable, even if not repeatable. One would not have expected less than that from one of J. Vansina's Wisconsin Ph.D. students, as Alagoa was. 
A short analysis of Alagoa's second work "A History of the Niger Delta...", which was a revision of his Wisconsin Ph.D. thesis is indispensable, I feel. As for the sources, the oral traditions from which Alagoa reconstructed the history of the Niger Delta, these were traditions of origin, "perhaps the most controversial type of oral literature"23) as Alagoa himșelf put it. Moreover, Ijo traditions were of the type of informally transmitted oral traditions, which implies that the danger of distortion by loss of memory is enlarged. Finally, Ijo traditions were the traditions of so-called "stateless" societies, i.e. societies that do not have central political institutions, whose past cannot be recovered according to many scholars ${ }^{24)}$. In view of the complexity of these sources Alagoa's attempt to extract from them historical information on migrations, the development of institutions, trade and cultural contacts with neighbouring peoples, was truly a Herculean task.

As for the contents, one major theme of the book was related to the political history of the Delta: This was the question of the influence of resp. the Atlantic trade (1), the influence of neighbouring peoples such as the Benin Empire (2) and internal factors on the development of institutions throughout the Niger Delta. It was at this point that Alagoa's virdication of the importance of internal factors of change apart from external ones became manifest. Said Alogoa about the political development of the Eastern Niger Delta:

\footnotetext{
"It is time to recognize that these states developed in response to a multiplicity of stimuli, some of which started before the arrival of the Europeans on the coast".25)
}

Alagoa described the economic cievelopment of these states--from a village system based on farming and fresh water fishing to one based on fishing and saltboiling- as; one resulting from a change in ecological environment. The changes from fishing village to city state were allegedly set into motion not so much by the European transatlantic trade, but by the local long--distance trade, which predated the Eurcpean presence. 26) Time and again ${ }^{27)}$ Alagoa emphasized that the local long-distance trade was a greater stimulus to the formation of city-state institutions than the Atlantic trade: 
"... the communities of the Delta were fully established before the Portuguese advent; and (...) had already established internal trade routes and structures upon which the overseas trade of the European visitors was engrafted" 28).

At the end of his major study Alagoa dropped the cautiousness of earlier formulations, and s.tated quite explicitly:

"... the case of the Eastern Delta States presents an example of development of political institutions and structures in response to local cicumstances" 29).

Alagoa's concluding remarks on migrations, economic history, the problems of dating oral traditions etc., were all of great interest. Yet, for the historiographer who looks for the familiar as well as for the new aspects of Alagoa's research, the tone of rehabilitation in which he ended his "History of the Niger Delta". was even more significant:

"The history of the centuries before 1800 shows that the socio-political systems developed among the Ijo of the Niger Delta were dynamic and capable of internal adjustments in response to new challenges and stimuli" 30). 


\section{Notes to Chapter Six:}

1. Ajayi \& Alagoa (1974), p. 113. See also Dike (1953): "African History and Self Government".

2. The original thesis was submitted to the University of Iondon in October 1963.

3. I.A. Akinjogbin (1967), p. 3

4. idem, p. 7

5. idem, p. 202

6. idem, p. 17

7. idem, p. 77

8. idem, p. 203

9. idem, p. 203

10. idem, p. 140

11. idem, p. 107

12. idem, p. 210

13. idem, p. 211

14. Ajayi \& Smith (1969), p. 63

15. Folayan, Kola (1967) and (1972).

16. Awe, Bolanle (1964): "The Rise of Ibadan as a Yoruba Power, 1851 - 1893". Unpublished Ph. D. thesis, Oxford 1964. (Not consulted). see also Awe, Bolanle (1965) and (1974).

17. S.A. Akintoye (1971), p. xx.

18. idem, p. $\mathrm{xv}$

19. idem, p. xix

20. E.J. Alagoa (1975), p. 178 .

21. This remark is more valid for the Nigerian historians dealing with the early pre-colonial era than the historians discussed in Chapter Five, Section 1.

22. See e.g. A.E. Afigbo (1966).

23. E.J. Alagoa (1972), p. 3.

24. idem, p. 5.

25. idem, p. 123 .

26. idem, p. 158-9.

27. see Alagoa (1975), p. 177; Alagoa (1971a), p. 330; Alagoa (1972), p. 177.

28. E.J. Alagoa (1975), p. 177.

29. E.J. Alagoa (1972), p. 159.

30. idem, p. 194. Compare Alagoa (1970). 
CHAPTER SEVEN

Nigerian Historians and the Colonial Past

When the Tanzanian historians N. Kimambo and A.J. Temu edited "A History of Tanzania" 1) they wrote in the preface to the book:

"There has been no attempt to deal with colonial administrative structures. This is because our main interest has been in the African himself" 2).

This remark was taken up by two sharp critics of the "New Eistoriography" of Dar es Salaam--to which Temu and Kimambo belonged and which was allegedly characterized by a neglect of the colonial period in favour of mythological "connexions" 3), between the nationalist or postindependence phase of African history and the precolonial one. The two critics, D. Denoon and A. Kuper, said in retort to the abovementioned remark by Kimambo and Temu:

"Historians of political development within colonial dependencies, in any part of the world, would be rightly appalled at such a self-imposed limitation" 4).

And...

"Scholars who regard the outside world's interventions in Africa
as having achieved more than nationalism, and who consjder that
colonialism has been replaced very frequently by neo-colonialism,
are not likely to be convinced by the implication that colonial
policy was of scant significance even during the colonial years" 5).

The detajls of this intersting academic dispute cannot detain us here, but the crux of the matter is that at one point in the development of Tanzanian historiography there was a tendency to overemphasize the importance of (and the continuity with) the precolonial past, particularly of African resistance to the Europeans, at the expense of the colonial period.

Was this anachronistic tendency, which was inspired by a nationalist concern with the present, evident in Nigerian historiography as we11?

To a certain extent it was, as has been demonstrated above. Yet, this imbalance of Nigerian historiography was only temporary. Nigerian historians were quick to fill this gap, and it is no exaggeration to speak about a real hausse in research on Nigerian's colonial past from 1965 onwards. This colonial history witten by 
Nigerians was colonial history with a difference; a difference which was a question of perspective mainly. The new colonial history exchanged the discredited Euro-centric perspective for an African perspective, and focussed upon the African side of the story of British colonial administration. Like its Eurocentric counterpart he "new" colonial history was preoccupied with questions of administration. However, it was not "the rulers of empire" who occupied the scene, but the ruled; their experience of British colonial administration, their reactions to British administrative action, and their initiatives in this encounter with the colonial masters, were central to this trend or type of Nigerian historiography. Therefore one may call it "New Administrative History". Before we turn to an analysis of this New Administrative History two other works of colonial history deserve some attention: Those by J.C. Anene and T.N. Tamuno. Both Anene and Tamuno belonged to "the first academic generation" of Nigerian historians, those who obtained their doctoral degrees in London, in the early sixties. Although their major works did not appear in print until the early seventies (resp. 1970 and 1972), the theses out of which they grew were submitted to the University of London in 1960 and 1962, resp.

A. Two Early Nigerian Historians and the Colonial Past: -tracing the origins of the nation as an administrative unit.

"It will probably come as a shock to the reading public to be confronted with what seems to amount to a defense of the Europeanimposed colonial boundaries" 6). With this remark J.C. Anene opened the Preface to this book "The International Boundaries of Nigeria, 1885-1960 - the framework of an Emergent Nation". The date of its publication, 1970, is misleading because it grew out of a thesis dating from 1960, while the revision for publication took place long before 1970. Probably his revision took place in 1966 (the date of the General Editor's Note ${ }^{7)}$ ) and in any case before 1968, the year of the author's untimely death as a result of "a fragile constitution that could not sustain the anxieties and disillusionments of the current conflicts in Nigeria" ${ }^{8)}$. 
Were the revisions of the original thesis substantial? And if they were, should one relate these revisions to the author's experience of the Nigerian Civil War? Or did the early sixties--when the book was actually conceived--form the frame of reference of this study? The conclusions of the book cannot leave any doubt as far as this question is concerned, for Anene ended the book on a note of optimism. Betraying no pessimism or fear of threats to Nigeria's territorial integrity from the inside or the outside, he wrote:

"It can be said that up to the moment no serious boundary question has been raised in Nigeria or by Nigeria's neighbours" 9).

In view of this optimism and in view of the fact that the comparison of thesis and book did not yield any substantial 10) differences, "International Boundaries" can be regarded as a work of early Nigerian historiography; as a product of the period of Nigerian independence.

Anene's work traced the origin and evolution of the framework of an African emergent nation, i.c. Nigeria, in the same way as other studies had traced the origins of nationalism and anticolonialism. This time there was no obsession with (trans-) continuity, but there was a same search for origins: The origins of Nigeria as an administrative unit; the origins of the boundaries within which Nigeria achieved independence in 1960.

At first sight the book might seem to differ from other works of early Nigerian historiography in that it covered the whole colonial period from 1885-1960. However, the period in which Nigeria's international boundaries were determined by the colonial powers was the most important. This was also the period of study in many other studies of early Nigerian historiography, as we have seen in chapter five.

There were more common features. The main theme of "International Boundaries" was the impact of Europear' encroachment on the Africans, or to put it more specific "the impact of colonial boundaries on the peoples in whose history the acts of partition were a major invention" 11). Like all Nigerian historical studies it examined African experience of European action i.c. the determination of Nigeria's boundaries by international European diplomacy. Anene set out to examine: 
"What is the relevance of the assumption that African tribes and groupes traditionally enjoyed coherence, only to find themselves and their territories disrupted by the colonial boundaries?" 12).

To answer this question he had to examine the ethnic situation of the boundary areas at the time the boundaries were created, and in particular the political and economic relations of the ethnic groups living there. Did this ethnic situation influence the outcome of European boundary negotiations? Did the boundaries that were finally created really disrupt traditionally homogenous groups? And finally, should (and could) Nigeria's boundaries be revised at the achievement of independence?

Anene believed they should not:

"One cannot escape the conclusion that the boundaries represented to a surprising degree the realities which existed at the time" 13).

Throughout his study he showed that at the time of the boundary negotiations the ethnic groups of the areas in question did not present a tidily uniform political, linguistic and cultural pattern. The fluidity of African boundaries, and the fact that the political systems were often out of harmony with ethnic distribution, made for such a complex situation that the nature and extent of indigenous frontiers could not have had more than marginal influence on the outcome of the boundary negotiations. Anene did not deny that the boundaries were created by alien diplomates, who often sacrificed African interests to diplomatic exigencies--knowingly or unknowingly; and that many ethnic groups were disrupted ${ }^{14}$ ). Yet, his "objective study in Colonial Boundary making" 15) compelled him to reject the "local criticisms of the boundaries of Nigeria which are based largely on traditions of past conquest, past glory, and mythical tribal unity" 16). Hence he called it "historically inaccurate and, in the conditions of today, dangerous to assert without important qualifications that the boundaries of Nigeria have disrupted long established communities" ${ }^{17)}$.

Anene surveyed all Nigerian internal boundaries, calling some "happy" (i.e. not disrupting the dominant ethnic groups) and some unfortunate. Yet even the "unhappy" ones could be preserved, Anene 
argued, since no problem of political irredentism was likely to

arise 18) - a real-politisch argument, one would say in German.

The conclusion which forces itself on the reader is that Anene was positively committed to the Nigerian nation-state within the boundaries which it inherited from the colonial era. His study was an overt defense of the existing boundaries in the face of "local criticism" and tribalist demands for revision. This was evident from the joy he expressed at the fact that the Nigerian nation-state--struggling to balance, repress or to transcend tribal loyalties--couid not allow itself to "show undue sensibility to a clamour by any zonal ethnic group for boundary revision calculated to satisfy tribal solidarity" 19).

Nevertheless, Anene's study was a far cry from a narrowly nationalist defense of the status quo. His claim to have written an 'objective' study appears quite justified, even if the historiographer will try to account for Anene's choice of subject by referring to the nationalist phase of African history during which the book was conceived. Anene's book was not a rigid defense of the existing boundaries. On the contrary. Breaking a lance for Pan- African cooperation, he even warned against an excessive devotion to international boundaries. If necessary, these should be rectified without war, on the basis of "calm dispassionate consideration of the factors involved, past factors as well as present factors" 20). This was the lesson to be learnt from the study: That the sanctity of boundaries was alien to traditional African frontiers, which had never been barriers to movement of peoples or cultural diffusion; and that--as Dike put it in the General Editor's Note--African statesmen should:

"borrow a leaf from their pre-colonial ancestors, whose attitudes to "international" frontiers between one ethnic group and the other was much less emotional, much less rigid and much more pragmatif, than that which many African leaders are adopting today" 21).

The demarcation of Nigeria's boundaries was only one aspect of the evolution of "the framework of the emergent nation of Nigeria". The other aspect of the process by which Nigeria achieved its present territorial framework concerned the internal or regional boundaries: 
The process of amalgamation of different areas which as a result of British colonial administration came to make up one state, namely modern Nigeria. This second aspect, the British administrative policy of amalgamating first Lagos with Yorubaland in 1906, then in 1914 Southern Nigera with Northern Nigeria was the subject of J.C. Anene's "Southern Nigeria in Transition, 1885-1906"--which will not be discussed here-- and of the study by T.N. Tamuno entitled "The Evolution of the Nigerian State-the Southern phase 1898-1914", published in 1972. The book was based on Tamuno's Ph.D. thesis which was written as early as 1962 under the title "The Development of British administrative control of Southern Nigeria 1900-1912: a study in the administration of Sir Ralph Moor, Sir William MacGregor and Sir Walter Egerton".

A glance at the two titles will be sufficient to convince the reader of the need to compare the original thesis with the version that was eventually published. This comparison shows how a model study in British (colonial) administrative history developed into a book relevant to the "evolving" Nigerian state. Also it reveals the changes in the frame of reference and commitment of the author and his changing view of the relevance of his research. If one takes the published versions first, its most striking aspect is its title "The Evolution of the Nigerian State...". Apparently, what was in 1962 still a study of Southern Nigeria's first three British governors, had become the Southern phase of the evolution of the Nigerian state in 1972. The main theme of the book was:

"The processes through which a common political entity, a central authority and a coo-ordinated economic and fiscal system developed in Southern Nigera until the 1914 amalgamation" (with Northern Nigeria) 23).

Central to the book was in other words the enlargement of scale which occurxed as a result of British administrative action: On the political plane by abolishing internal boundaries and by gradually amalgamating the different territories; on the economic plane by pooling the resources and by making the regions economically interdependent; on the social plane by centralizing the social services. In the first chapters Tamuno expounded how British administration was 
established, and how the British came to control Southern Nigeria. In the next chapters he analysed how this "Mild Autocracy" actually worked: The internal pressures and checks on the British side, and the relations between rulers and ruled, e.g. in executive and legislative councils. The last chapters dealt with the results of British administration, at least those aspects which contributed to the evolution of the Nigerian state. It was this outcome of British administration, rather than "the Nigerian response to colonialism and its aftermath" 24) that had Tamuno's basic interest. Essentially the actual research on which the book was based was limited to Southern Nigeria. It was the author who--from hindsight-put this study of Southern Nigeria in a national framework, in the framework of the Nigerian state which came into existence in 1960 , but which was foreshadowed in the amalgamation of North and South in 1914, the terminus ad quem of Tamuno's study. This concern with tracing the origins of the independent Nigerian state, i.c. how it came to have the legal framework and the boundarjes which it had at the time of its independence, is a legitimate concern and one which is socially relevant to the new states"in search of their indentity". Yet for Tamuno it was more than a concern. It was a positive commitment to the Nigerian state as it developed from colonial origins. This positive commitment was evident for example, from Tamuno's evaluation of British colonialism:

"Despite some negative aspects of British colonialism in Southern and Northern Nigeria in this era, Britain made a positive contribution to the evolution of the Nigerian state" 25).

The most baffling thing is not this positive commitment to the Nigerian state as it was in 1962, when the original thesis was written, but the fact that Tamuno's concern with the national Eramework and the political and juridical aspects of its evolution was much more explicit in 1972, when Nigeria was twelve years old, than in 1962, two years after its independence! Should one conclude that historiography obviously is a slow registrator of changes in society?

Fortunately for historians there is an alternative explanation for Tamuno's concern for an positive commitment to the undivided Nigerian nation. After all the book appeared in 1972 (the Preface dated from 1970). Hence the revised edition must have been prepared during or at the end of the Civil War. It seens justified to relate 
Tamuno's preoccupation with the administrative framework of an undivided Nigeria to the experience of the Civil War, for the author himself brought up the Civil War quite suddenly at the end of his book expressing his joy that: "The end of Civil war saved the Nigerian state from breaking up into its precolonial units (...)" 27). He even seemed more or less embarassed by the logical implication of his study, that the Nigeria saved from disintegration between 1966 and 1970 was a British creation ${ }^{28)}$. This had been the argument which the secessionists--with whom Tamuno did not agree-- had used to justify the secession of Biafra. Tamuno disproved the argument --and thereby tried to legitimize the continued existence of the Nigerian state as it emerged from the Civil War--by referring to the social and emotional investments into the Nigerian state made by both the Nigerian leaders and masses from 1914 onwards:

"If therefore the credit of creating the Nigerian state rightly belonged to Britain, that of its further consolidation rests squarely with the British personnel as well as Nigerians before and after independence" 29).

B. The New Administrative History: The African side of the story of British Colonial Administration.

In the mid-sixties a range of case-studies of British administrative practice in Nigeria began to appear. The major representatives of this new administrative history were A.E. Afigbo, O. Ikime, Ph. Igbage, J.A. Atanda and A.I. Asiwaju, who all concentrated upon areas belonging to present day Southern Nigeria. As for the new administrative history of Northern Nigeria, I have not come accross any published study of this kind 30 ).

Although each of the above-mentioned historians did research on a specific area or a specific ethnic group, the period undex study (approximately 1900-1940-50) was roughly the same in all works. Also, they all wrote on essentially the same subject from a common --African--perspective, basing their works on metropolitan and local archives, newspapers, "local histories", secondary works, and oral eye-witnesses of the events under study. The new administrative historians set great store by their use of oral evidence and the African perspective of their work. Asiwaju, for example, took the 
co-authors of the book "France and Britain in Africa" 31) --a work written almost exclusively by Western scholars-- to task for neglecting oral evidence or existing historical studies based on oral evidence:

"So long as African historians on both sides of the Northern Atlantic remain contented with the drudgery of crowding the archives of Europe and former colonial capitals and flying in aeroplanes over the really crucial African villages, so long will the knowledge of colonial realities as perceived by Africans subjected to the colonial administrations continue to elude them". 32)

Since the body of new administrative historical studies is quite substantial and since it consists of meticulously researched casestudies, a detailed and in depth analysis of the work of each 'new administrative' historian cannot detain us here. For the purpose of this essay, it suffices to look at the main themes of the new administrative history, illustrated by a few examples.

Three closely related themes recurred in all these case studies of British colonial practice in Nigeria; the questions of indirect rule (1); the evolution of the position of the chief under British rule (2); and thirdly, African resistance to British local government policy, i.e. the policy of indirect rule (3).

1. The question of indirect rule - i.e. the British attempt to rule the conquered peoples of Nigeria through what was thought to be their indigenous political organisation, became the subject of a lively historical debate. ${ }^{33)}$ All new administrative historians who tried to answer the questions whether British colonial policy in the specific area under study could be called "indirect rule" attempted to make a genuine assessment of British rule from the perspective of the ruled. The theoretical debate on the criteria and essentialia of indirect rule cannot be analysed here in detail. Important for our argument here is the redefinition of indirect rule in terms of how it was experienced by the "Nigerian" subjects, not as it was formulated by British politicians. This redefinition implied a re-assessment of the role of the famous Lord Lugard--traditionally regarded as the father of Indirect Rule-- and of Lugardism, which was no longer taken as the only, but as only one particular systematization of indirect rule, namely one modelled upon the example of Northern Nigerian Emirates. 
Three stages in the development of British indirect rule--varying with each area under study-- recurred in almost all new administrative studies. First, the period before 1914, when only jurisdictional powers were effectively devolved on the local authority, the chief. Secondly, the period which began with the introduction of the Northern Nigerian version of indirect rule into the South by Lord Lugard, who was Governor of Nigeria between 1914 and 1918. This period signified a golden age for the British admininstrative representatives, the chiefs, who often became more powerful in a much wider area than they could ever have been under the traditional system. It was among other things their abuses of power that bred resistance among the local population, giving rise to violent outbreaks such as the Women Riots of 1929 in Eastern Nigeria. These hostile reactions compelled the British to revise their system of local government and to introduce the principle of decentralisation and of increased representation, which gave the non-chiefly elements of the subject societies--a.o. the educated-- more avenues for administrative activities. Particularly the (parts of the) studies dealing with the riots and outbreaks demonstrated the double theme of most new administrative history: the impact of this changing policy of local government upon Britain's Nigerian subjects; and the impact of the subjects upon the formulation of British policy.

\section{The Evolution of the Chieftaincy Institution.}

Who were the African subjects whose experience of British administration was studied in the new administrative history? The chiefs and their vicissitudes in the different phases of indirect rule received most attention. Particularly the chief's enormous increase of power in the period 1914-1931 featured in many studies. One of these was J.A. Atanda's book "The New Oyo Empire - indirect rule and change in Western Nigeria, 1894-1934"(1973), which related how the Alafin of Oyo--the ineffective ruler of an empire which had declined as early as the end of the eighteenth century--was made into the paramount ruler of the whole of Yorubaland. This policy--based on erroneous ideas of the earlier extent of the old oyo Empire and of the nature of the authority of the traditional Alafin-- was responsible for the British creation of a "Sole Native Authority" whose power and area 
of jurisdiction were definitely untraditional and artificial. In this case the break-up of the New Oyo Empire (1931-1934) was not the result of hostile reactions of the ordinary people, but of a change of British policy and administrative personnel and the efforts of the educated elite pressing for more influence.

The evolution of the chieftaincy was also the central theme of the first major publication of the University of Ife Pxess ir 1970, edited by M. Crowder and O. Ikime. 34) It was entitled "West African Chiefs- their changing status under colonial rule and independence" and contained essays by almost all 'new administrative historians' discussed in this section. J.A. Atanda, E.A. Ayandele and S.A. Akintoye described the changing status of chiefs in Yorubaland (resp. Oyo, Ijebuland and Ekiti), all of whom saw their authority vastly increased at one time between 1914 and 1950. Ph. Igbafe and O. Ikime analysed the evolution of the chieftaincy in Benin and the Niger Delta, 36) whereas A.I. Asiwaju introduced a comparative dimension into the debate by comparing the status of two Western Yoruba rulers, one of whom was living on the Nigerian side of the border (at that time English), the other on the Dahomean side--then French territory.

3. Resistance to the British policy of local government, indirect rule. The third major theme--corresponding to the third stage in the development of indirect rule-- was 'Nigerian' resistance to the British policy of local government: The Women's Riot of 1929 in Eastern Nigeria directed against the Native Court and Warrant Chief system was analysed by A.E. Afigbo, 38) whereas O. Ikime described the Anti-Tax Riots in Warri Province (1927-28), 39) which were allegedly an expression of general dissatisfaction with British rule, and wexe directed against the African administrative personnel, in particular the warrant chiefs and court scribes.

Both Afigbo and Ikime highlighted the formative influence of this African reaction on the change of British colonial policy, outlined above. For Afigbo the Women's Riot had an additional significance, since it was allegedly the end of an epoch:

"This Women's Riot of 1929 was the last of the conservative revolts against the colonial regime in Nigeria and for that reason it is an important landmark in the history of the nationalist movement...." 40). 
"After 1929 the movement for independence in Nigeria passed completely into the hands of the educated elements and the programme of a complete return to the pre-colonial status quo was abandoned as untenable and undesirable". 41)

Allegedly the Women's Riot brought home to both the British and the Nigerians that not the traditional chiefly elements should be the mainstay of the policy of educating the Nigerians for self-government, but the detribalized minority. Afigbo was certainly stretching the point, one feels, when he concluded:

"The dawn of this period of adjustment on two fronts indeed marked the earliest beginnings of the end of the colonial regime in Nigeria. Here we may see the place of popular reaction to British rule in Eastern Nigeria in the movement for Nigerian independence". 42)

This brings us to the questions of what the "new administrative historians" considered to be the relevance of their studies to their own times. Afigbo betrayed the by now familiar preoccupation with the continuity of African history, when he located the roots of nationalism or "the origin of the movement for Nigerian independence" in the Woman's Riot which was the subject of his article. This was a rather far-fetched interpretation, one feels, which did not feature in his major work "The warrant Chiefs-Indirect rule in Southeastern Nigeria, 1891-1929" (1972). In this work there was no evidence of an attempt to force the Women's Riot into a nationalist framework. If anything was of direct relevance to the twentieth-century predicament, it was Agifbo"s rehabilitation of Ibo traditional political systems, for he argued that:

"The failure of the system (the warrant Chief System, a form of British indirect rule) is not primarily, as is usually thought, an adverse commentary on the political organisation of the Ibo and their neighbours, but on the ability of the British in the first four decades of their rule to understand and solve the administrative problems presented them by Ibo, Ibibio, Ijo and ogojo society"

Although he modified his statement thus:

"To some extent, however, it also reflected the failure of the natives to modify their indigenous system enough to meet the needs of the changed times". 43)

This same element of rehabilitation was evident in Afigbo's article on Herbert Richard Palmer, 44) in which he held British ignorance of Nigeria, British prejudice and the lack of empiricism in the British approach to local government in the period before 1930, rather than 
supposed shortcomings of the decentralized political organisation of the indigenous inhabitants, responsible for the failure of indirect rule.

The attempt to relate the preoccupation of Nigerian academic historians to the times and environment in which they wrote is one of the stated purposes of this essay. It is a hazardous undertaking however, particularly in the absence of manifesto-like statements such as that of Afigbo mentioned above. The suggestions offered here cannot claim to be more than tentative answers to the question of why Nigerian historians turned in force to the study of colonial history. Before turning to the answers to this question, one should note that "new administrative history" was not very different from "early" Nigerian historiography. It showed most of the limitations and imbalances characteristic of the research done on the Scramble era: It showed the same almost exclusive concern with political history. It dealt with óne factor of change only, i.e. the Colonial Administration, at the expense of many other external and internal factors of change operative during the colonial period: Social, ideological, religious, economic, etc. This limitation is inherent to administrative history everywhere and always, irrespective of the fact whether it is written from the perspective of the ruler or the ruled. Yet even within this administrative approach, the priority given to political aspects and effects was obvious in the new administrative history. In some studies, such as that by A.I. Asiwaju, 45) the social, economic and cultural impact of the colonial administration did feature, it is true, but in general the machinery of local government and its political implications for the subjects received most attention.

It is significant that this bias has been criticised fxom within the ranks of the "new administrative historians" themselves. A.E. Afigbo disapproved of the study of British and French administrative systems in West Africa through a study of the changing status of the chief,

"for it accepts the partial vision of the African socio-political reality which bedevilled European policies and their practical application". 
"Only through an investigation of the fates and fortunes of not only the chiefs, but also those other social, political, ritual and ideological institutions which helped to give African kingship and leadership their characteristic form, can we come to a proper appreciation of the extent to which the West African chief was de-Africanized under colonial rule: French or British style". 46)

The new administrative history was 'limited' in another sense, namely, in the geographical area it studied, i.c. what used to be British Souther Nigeria. In this respect it was again comparable to the 'early' Nigerian historiography, and the same is true for the third limitation of new administrative history:

The tendency to write the history of "the cream of society" rather than that of the common people. In the historical studies dealing with the pre-colonial and scramble era this partiality in favour of the so-called aristocracy expressed itself in the pre-occupation with the chiefs who resisted British encroachment. In the new administrative history this traditional, local elite was put into the limelight again, since they headed local government; while the educated elite--as clerks in charge of the various departments of the administration-- featured in these studies to a lesser extent. The masses came in only occasionally, e.g. when the riots, which flared up from time to time, were analysed. E.A. Ayandele, writing in 1969, took the "new administrative historians" to task for neglecting the common people, and noted:

"These accounts, largely because of the nature of the documentary sources on which they have relied give prominence to the British and to the two classes of patricians, and ignore the unlettered masses". 47)

Ayandele was right, I believe, in contending that to the masses-.. he was referring to the Ijebu masses in particular--

"...a history of British rule, portrayed through the spectacles of the Native Administration, would not be acceptable as their history". 48)

Perhaps Ayandele exaggerated, for some authors did bring out the common people's perception of colonial rule: A.I. Asiwaju's chapter on the Protest Migrations from the French to the British side of the (present) Dahomey-Nigeria border was a good illustration of this concern with the common people. 
He even tried to retrace popular sentiments towards French and British local administration through an analysis of popular songs and the names people gave to their newly created settlements.

49) Afigbo's moving account of how he tried to involve women in his research on the Women's Riot of 1929 demonstrated this same concern with the pexception of colonial rule by the common people, in spite of the fact tint in this particular case he had to give up his attempt when a ninety-year ola lady literally shovelled him out of her hut with a broom. 50) Ayandele's criticism may have been unfair, also since the gap between elite and masses was not as wide as Ayandele would have one believe. 51; Apart of all this, generally speaking, Ayandele was quite right to say that the "new administrative historians" did not portray British colonial practice as perceived and experienced by the common people, but as experienced by the chiefs. Concluding one can say that new administrative history "rewrote" from an African perspective the history of the colonial period as Dike and Ajayi had "rewritten" the history of the Scrambie era. There were no essential differences; both groups of historians had the same "academic world view", or-- to use the term of Thomas S. Kuhn, they belonged to the same "paradigm community".

Returning to the question of why Nigerian historians turned to the study of the colonial past, one should take into account first of all the internal forces of change operative within the historical profession, the internal evolution of the discipline. The historians of the second academic generation may have turned to the study of the colonial period simply because it had not yet been covered by the first Nigerian academic historians. Also the source material for the colonial period was as abundant or even more abundant than for the late pre-colonial and scramble era: The local colonial archives in district and divisional capitals were relatively unexplored and ready at hand for students doing theix postgraduate research in Nigeria itself. The same was true for oral evidence, which could be collected by students-- often in their own ethnic group-from people who had actuaily lived through the colonial era, and who had been eye-witnesses of the events under study. This represented not only an excellent opportunity for research in Nigeria, but an urgent task as well in view of the age of many informants. 
Another possible explanation might be the influence of the British academic tradition, in which African history had always been regarded as a subdivision of Imperial or Colonial History, and which had always been preoccupied with questions of policy-making and administration. Rewriting this type of British colonial history--changing the Eurocentric for an African focus--implied a change in interpretation and evaluation, but not necessarily discarding the specific preoccupations and limitations of this type of history as a whole. It may be noted that at least two "new administrative historians" (A.E. Afigbo and O. Ikime) wrote their Ph.D. theses under the supervision of a Nigerian historian (i.C. J.C. Anene) who had been trained in the British tradition of colonial Administrative history.

As for the political, social and economic environment in which the Nigerian historians wrote their studies, this is very difficult to measure. Although all "new administrative historians" overtly rejected the "colonialist" colonial history which they pledged to rewrite, they did not 'manifest' their views of the relevance of their own historical research.

Was there a relation between the major themes of the new administrative history and the problems of internal administration or local government which beset Nigeria after independence? 53)

I have not come across any direct reference to current administrative problems in the new administrative historical works, although generally Nigerian historians are quick to seize opportunities to emphasize the direct social and political relevance of their research. Moreover, most of the studies described the fortunes of the "native authorities", in particular the chiefs, only until the 1940s or 1950s, with the exception of "West African Chiefs", edited by M. Crowder and O. Ikime (1970). Nevertheless, even if there was no direct relation between historical analysis and current political issues, this is not to say that the historians under study were not concerned with the problems of an undigested colonial heritage with which Nigeria was struggling. This was evident from the way A.I. Asiwaju defined the relevance of his comparative study of British and French administrative practice in Western Yorubaland (i.e. at present the area on both sides of the Nigerian/Dahomean border). 
"Essentially then the book was originally conceived as an academic exercise", 54) he admitted, but at a time when West African states were trying to realize a political, cultural and economic harmonisation through the establishment of common institutions, the study might be of practical use; it might help government policy makers and pianning authorities to arrive at a more detailed appreciation of the historical framework and problems involved.

Another effort to contribute to a solution--or at least understanding-- of one aspect of the undigested colonial heritage was the study by 0 . Ikime called "Niger Delta Rivalry: Itsekiri-Urhobo Relations and the European Presence 1884-1936" (1969). This work was unique among the new administrative historical works since it examined the impact of British conquest ând British administration upon two Nigerian ethnic groups, or rather upon the mutual relations of two Nigerian ethnic groups, the Itsekiri and the Urhobo. Ikime expressed the hope that his study would be relevant to modern Nigeria since it threw light upon:

"...the tension between the Itsekiri and the Urhobo which has been a noticeable feature of contemporary politics, has its roots in the colonial period".

"Hence, although the present work is essentially a case study, it is hoped that it may serve to inspire work on similar lines, which should ultimately be of national significance". 55)

In his desire to write history that would be of relevance to the nation Ikime conformed to the programme "manifested" in the early sixties. Yet, in contrast with the early Nigerian historians, Ikime's frame of reference was no longer the anti-colonial struggle for independence, or African nationalism, but national disunity; that is to say, the phenomenon of ethnic "nationalism" or tribalism at the time of writing: The Nigerian Civil War (1967-1970). Ikime did show no preoccupation with demonstrating the (trans-) continuity of the precolonial and post-colonial era, but highlighted the changes which took place during the colonial period. The search for origins was not a search for the origins of present success (such as anti-colonial resistance or early African "nationalism") but an attempt to locate the origin and trace the causes of a national disease, namely ethnic strife.

Ikime traced the Itsekiri-Urhobo relations through each phase of British activity in the Niger Delta: 
-In the pre-colonial era the two groups were more or less in balance, but this balance was upset by the slave trade, and even more by the abolition of the slave trade which gave rise to the Itsekiri practice of incorporating Urhobo slaves into their social system, instead of exporting them.

-The era of the Itsekiri chief Nana (1884-1894), who exploited his position on the coast to dominate Urhobo-European trade, strenghtened the tendency towards inequality of the two groups.

-The period of British penetration into Urhoboland (1891-1914) on the one hand favoured the Itsekiri whom the British used as their instruments in the occupation of Urhoboland; on the other hand it steadily undermined the Itsekiri position as middlemen of the UrhoboEuropean trade.

-In 1914 the British made the Itsekiri chief Dogho paramount chief of both Itsekiri and Urhobo. This led to great resentment among the Urhobo who had to share common judicial institutions with the Itsekiri by whom they were dominated in every field.

-In the 1930s finally, the reorganisation of indirect rule, which resulted in separate institutions for both groups, enhanced the cohesion of each and emphasized their separateness.

"At the end of the period covered by this work the Itsekiri and Urhobo stood face to face in two organized blocs each extremely touchy about its "ancient" rights and competing with each other in the achievement of progress". 56)

In what way could Ikime's study be of national significance? How did Ikime contribute to a solution of the phenomenon of "ethnic nationalism" or tribalism, which he called "one of Nigeria's major problems at the time of writing" (i.e. 1969). 57)

He did so through his attempt to demythologize Itsekiri-Urhobo history; through the destruction of historical myths not invented by the Europeans this time, but by the Itsekiri and Urhobo themselves. His study was an exercise in the demythologization of Nigerian history as it was interpreted and used by both Itsekiri and Urhobo who based claims and counterclaims on former 'rights' and power. Thus Ikjme set out to disprove the Itsekiri myth that the Urhobo had been Itsekiri slaves, by demonstrating that the Urhobo integrated into the Itsekiri social systems were slaves which could no longer be exported as a result of abolition, or who were actually temporary pledges in case of insolvency. 
Ikime also disproved the Urhobo myth that the Itsekiri were responsible. for the establishment of British control over Urhoboland by stating that:

"...the decisive factor in this regard were clearly British military patrols and the frequent visits of British political officers". 58)

In the 1930s the Itsekiri had argued that Chief Dogho was the best evidence for Itsekiri overrule over the Urhobo in years past, and hence, by implication in the present. Ikime disproved this myth since

"Dogho was the instrument of British power rather than the Itsekiri power",

and,

"(..) the Urhobo constantly protested against the authority exercised over them by Dogho".

Ikime continued:

"Indeed the career of Dogho is the best illustration of how the policies of the British administration led to the growth of conflict between the Itsekiri and the Urhobo". 59)

The question of who was responsible was crucial to Ikime's study:

"As the phenomenon of "ethnic nationalism" or tribalism is one of Nigeria's major problems at the time of writing, one may be permitted to pose the question of what has been responsible for the tensions and conflicts discussed in this work. It is easy to see the conflicts as arising from British colonial policies. While this is largely true, it is to be stressed that British colonial policy was not deliberately formulated to produce tensions and conflicts.

(...) In a sense, therefore, the issue can be seen as one of the problems of adjustment to a new political and social order imposed by the colonial power". 60)

This then was the moral of the story: That not the Itsekiri and urhobo were to blame, but that impersonal factors of geography (coast versus hinterland) 61) and social adjustment; and to some extent the former colonizer was responsible for tribal tension in the present. This conclusion could indeed claim to contribute to clearing the atmosphere between the Itsekiri and Urhobo and to point the way to future peace and cooperation between them.

C. Other Nigerian Historical Works dealing with the Colonial Era.

Not all colonial administrative history written after 1965 was "new administrative history". T.N. Tamuno's study "Nigeria and Elective Representation 1923-1947" (1966) had hardly anything in common with new 
administrative history, apart from an interest in the machinery of aaministration. The book was essentially a survey of all elections to the Nigerian Legislative Council, from the introduction of the elective principle in 1923 until 1947. It was a "technical" study, dealing with the regulations governing qualifications for the franchise and the conduct of the elections. It described the rise of political parties, the social, educational and ethnic background of the candidates, and the actual course of events in all elections from 1923 to 1947. These elections were a very small affair. For nearly three decades (until 1951) Nigeria had only four elected representatives (three from Lagos and one from Calabar), who made up a numerically insignificant minority of the Legislative Council. Hence-- in contrast to what the title of the book suggested-- only the political scene of the capital, Lagos, was actually described. Yet, it is not so much the narrowness of the stage, or the small number of candidates involved that made the book's approach so 'narrow'. The book was "bloodless" 62) since it was limited to the political machinery, deliberately excluding the stuff of politics. The activities of the elected members, their interaction with other (nominated) members of the Council and with the rest of the Lagos community did not figure at all.

The claim that this study was of "a certain topical interesc" for the Nigerian political scene anno 1966, when "this whole question of the functioning of the electoral system in Nigeria and the distribution of the national vote" 63) were once again raised, was not very convincing, for the only conclusion of Tamuno's study was this: That in spite of the fact that the number of elective seats in Nigeria stagnated for almost a quarter of a century, the experiment of 1922, giving a - severely limited - franchise to Nigeria for use in Legislative Council election was allegedly "a fairly successful experiment". "Nigerians were not found incapable of using the franchise" 64), nor should this stagnation be attributed to Nigerian apathy. The preoccupation with the technical aspects of colonial administration does not make for fascinating reading. This holds true as well for another contribution to Nigeria's administrative history by Tamuno, "The Police in Modern Nigeria 1961 - 1965-- Origins, Development and Role" (1970). In spite of Tamuno"s disavowal in the Preface, his work 
was an "official" history, not only heavily dependent on official sources, but also written from an "official" point of view. As his critic in the Journal of African History had it, 65) Tamuno did not delve beyond the official answers. Hence instead of an analysis of the police within the context of Nigerian history and society one is presented with the police's own conceptualization of their role and function in society. Discussirig the question of police corruption, for example, Tamuno was ovextly apologetic, presenting the reader with arguments such as these: That after all the problems confronting the police were very complex and that "their particular duties in crime control exposed them to regular contact with criminals and other shady characters of the underworld" 66). The best illustration of Tamuno's "official" approach was the fact that he evaluated the 104 years the Nigerian police existed in terms of public funds and government attention:

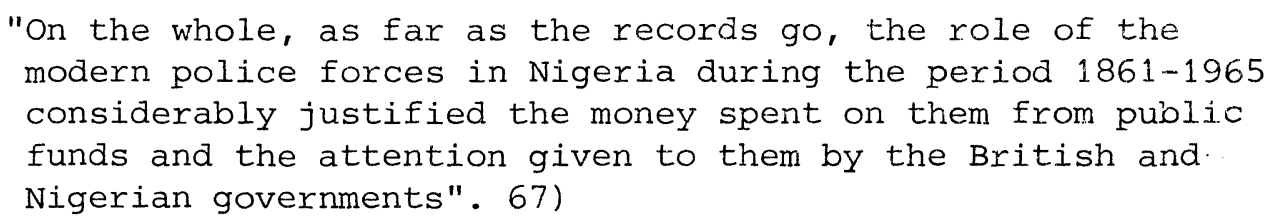

Tamuno's study was essentially concerned with the period after 1930. Yet he did bring in the precolonial background by analysing the apparatus of precolonial communities to maintain law and order and to prevent, detect and punish crime.

\footnotetext{
"The examination of the traditional law enforcement agencies has revealed that even in pre-colonial communities such institutions were adequate to their task. It has also been demonstrated that Nigerian communities then were not lawless or disorderly". 68)
}

This concern with the rehabilitation of the precolonial institutions as well as with demonstrating their continued performance during the colonial period, may be interesting in view of similar concerns pointed out above. However, the argumentation was not very convincing, nor did it have any manifest relevance to the rest of the study.

It would be incorrect to contend that all studies of Nigeria's colonial past written by Nigerian historians belonged to the category of administrative or new administrative history. There were exceptions: An economic history of Nigeria from 1860 to 1960 was written by the economist R.O. Ekundare. (69) "The History of Educational Policy in Nigeria from 1842 to 1939" was analysed in the unpublished ph.D.thesis of the historian A. Fajana (Ibadan 1969), whereas the educationalist 
A. Babs Fafunwa updated and published "A History of Nigerian Education (1928-1970)". 70)

However, these studies formed a numerically insignificant part of the Nigerian historiography dealing with the colonial period, and will not be discussed in this essay for reasons of time, space and coherence of the argument.

A historiographical survey can never cover everything, and can only rarely be completely up to date. Nevertheless a short look at Nigerian historiography dealing with contemporary history -here used in the sense of history of the post-1945 era-- is indispensable, even if only to conclude that it is next to non-existent. 


\section{Notes to Chapter Seven}

1. published in 1969.

2. quoted in Denoon \& Kuper (1970), p. 335.

3. T.O. Ranger (1968a); I. Wallerstein (1973), p. 4.

4. Denoon \& Kuper (1970), p. 335.

5. idem, p. 347.

6. J.C. Anene (1970), p. xv

7. idem, p. xiii: General Editor's Note by K.O. Dike (Gen. Ed. of Ibadan History series).

8. J.C. Anene (1970), Memorial Note by J.F.A. Ajayi dating from 1969, p. ix.

9. J.C. Anene (1970), p. 295. Note that Anene is actually concerned with Nigeria's international boundaries.

10. Title of the thesis submitted for the degree of Ph.D. of the University of London, May 1960:

"The Boundary Arrangements for Nigeria 1884-1900; an objective study in colonial boundary making".

11. J.C. Anene (1970), p. x. Note also the limited use of oral sources other than interviews with some inhabitants of the present $(=1960)$ border area about their satisfaction or discontent with the boundaries.

12. J.C. Anene (1970), p. 5.

13. idem, p. 288 .

14. idem, p. 285.

15. Anene's original thesis' subtitle was: "An Objective Study in Colonial Boundary making".

16. Anene's unpublished Ph.D. thesis (1960), p. 408.

17. idem; compare Anene (1970), Preface, p. xv.

18. J.C. Anene (1970), p. 289.

19. idem, p. 296.

20. idem, p. 288.

21. idem, p. xiii (Dike); compare J.C. Anene (1970), Preface, p. xvi.

22. J.C. Anene (1966), based on his M.A. thesis (London 1952) entitled "The Establishment and Consolidation of Imperial Government in Southern Nigeria (1891-1904); theory and practice in a colonial Protectorate".

Essentially this study was an example of the making of a Colonial Protectorate, tracing the stages in the growth of British administrative control over Southern Nigeria and to some extent the economic and social impact of British rule. In its almost exclusive concern with the British administration it belonged to the tradition of British Colonial or Imperial history. see for a review O. Ikime (1968), JHSN.

23. Tamuno (1972), p. xiv.

24. idem, text on book cover.

25. idem, p. 348 . 
26. One should keep in mind that the original thesis was a Iondon Ph.D. thesis. Therefore, the thesis may well have been influenced by the impact of the British academic tradition and the fact that ramuno depended mainly on British sources.

27. idem, p. 350 .

28. idem

29. idem.

30. According to Aderibigbe (1973), C.N. Ubah wrote an unpublished thesis on "The Administration of Kano Emirate under the British 1900-1930" (1973), while P.K. Tibenderana prepared a thesis on "Sokoto Province under the British Rule 1900-1947". (Aderibigbe (1973), pp. 15 \& 18) A. Fika wrote a Ph.D. thesis (London 1973) on "The Political and Economic Reorientation of Kano Emirate 1882-1940".

31. Gifford, P. \& W. Roger Louis (1971).

32. I.A. Asiwaju (1974a), p. 565,

33. see Crowder, M. \& O. Ikime (1970); Ikime, O. (1968); Igbafe, Ph.(1967a); Afigbo, A.E. (1967a).

34. Crowder, M. \& O. Ikime (1970).

35. see J.A. Atanda (1970); E.A. Ayandele (1970a); S.A. Akintoye (1970).

36. Ph. Igbafe (1970); O. Ikime (1970).

37. I.A. Asiwaju (1970).

38. A.E. Agifbo (1966a).

39. O. Ikime (1966).

40. A.E. Afigbo (1966a), p. 555.

41. idem, p. 556.

42. idem, p. 557.

43. A.E. Afigbo (1972), Preface, p. xii. Compare p. 52.

44. A.E. Afigbo (1965).

45. I.A. Asiwaju (1976).

46. A.t. Afigbo (1971), p. 102. In my opinion Afigbo's own work published in 1972 and based on his Ph.D. thesis submitted to the University of Ibadan in 1964, possessed the very features he criticised in this review article.

47. E.A. Ayandele (1969), p. 29.

He might have referred to the nature of cral evidence as well, since the most knowledgeable informants interviewed were the still surviving chiefs (or their descendants) and the "educated elements" who had been employed in the local administration, e.g. as auxiliaries to chiefs.

48. idem.

49. I.A. Asiwaju (1976), Chapter Six.

50. A.E. Afigbo (1966), Part One: Collecting the Evidence. 
51. Compare Crowder, M. \& O. Ikime (1970), Introduction, p. xxvi, in which the authors affirmed that the literate African recruits in local government service during Indirect Rule-- hence figuring in the new administrative historical works-- did not belong to the highly educated elite.

52. T.S. Kuhn (1962).

53. M. Crowder $\left(1973,1962^{1)}\right.$, p. 313.

54. I.A. Asiwaju (1976), p. 7.

55. O. Ikime (1969), p. xviii.

56. idem, p. 262 .

57. idem, p. 272.

58. idem, p. 166.

59. idem, p. 219.

60. idem, p. 272.

61. idem, p. 273.

62. D.H. Jones (1967), p. 367.

63. T.N. Tamuno (1966), text on book cover.

64. T.N. Tamuno (1966), p. 121.

65. D.C. Dorward (1973).

66. T.N. Tamuno (1970), p. 286.

67. idem, p. 293.

68. idem, p. 282.

69. R.O. Ekundare (1973).

70. A. Babs Fafunwa (1971). 
Nigerian Historiography on the Recent Past

Until the early seventies there was practically no work of professional Nigerian hystoriography which dealt with the period after 1945. The study of the recent past was only rarely the concern of professional historical research and was generally left to political scientists. Why this was so is hard to say. Was research on contemporary affairs hindered by a repressive political atmosphere? Was it neglected because the archives for the recent period were not yet accessible to the historian? Or did the preoccupation with pre-colonial and colonial history leave the historian no time for research into the recent past? After all, the number of professionaNigerian historians in the decade following independence was limited-even if it was enormous by West African standards.

Howbeit, new works attempting to fill this gap are on their way. The Nigerian Civil war was the subject of a study by 0 . Balogun entitled "The tragic years: Nigeria in crisis 1966-1970" (1973) ${ }^{1}$, while A.B. Aderibigbe announced stuaies (or a cooparative study?) on the Nigerian Civil war by O. Ikime, J.F.A. Ajayi, A.B. Aderibigbe and A. Smith (British) ${ }^{2)}$. The discussion here will be limited to G.O. Olusanya, author of quite a number of articles in professional journals such as the Journal of Modern African Studies, Odu, Africa Quarterly and the Journal of the Historical. Society of Nigeria, and of a more substantial work--based on his Toronto Ph.D. thesis--entitled "The second World War and Politics in ivigeria 1939-1953" (1973).

Subject of the book was the rise and development of the nationalist movement in Nigeria during and after the second World war. In a sense Olusanya continued where Tamuno (1966) left off, but in contrast to the latter Olusanya focussed upon the politics of protest. In his second chapter, for example--dealing with the constitutional and political development from 1914 to 1939-- Olusanya did not attempt to disentangle the technical niceties of the constitution of 1922 , which introduced a Legislative Council for Lagos, but instead, 
analysed the complaints and demands of the Nigerian representatives to this Council. Next (in the chapters 3 to 5) Olusanya discussed those factors which influenced the growth of Nigerian nationalism before 1939: The missionary factor, the First world war and the Pan Negro Movement, the Indian example, the activities of West African students in London, the impact of the Italo-Ethiopian crisis and the emergence of the first National Political Organisation (i.e. the Nigerian Youth Movement) in 1934. During the war (1939-1945) the politics of protest were continued but the period of organised political activity, witnessing the emergence of mass political parties did not begin until after 1945, for reasons elaborated in chapter five. From 1945 until 1950 the Nigerian nationalist movement went through a short period or political radicalism which petered out in a bickering on constitution making and in ethnic and regional hostilities.

The period 1951-1953 witnessed a dead-lock in the Nigerian constitutional deliberations over the question of regional representation at the Centre, and a polarisation of the three Regions (Northern, Western and Southern Nigeria) and the three major ethnic groups, the Hausa, Yoruba and Ibo. Olusanya was very bitter about this period:

"The period after 1950 which witnessed the entrenchment of ethnic politics in Nigeria was therefore the most uninspiring in the history of the nationalist movement in the country". 3)

This then was, I feel, the most striking aspect of Ojusanya's study, its highly critical, even negative attitude towards the Nigerian nationalist movement. 4 )
"Unfortunately, as a result of uninspiring and poor leadership, and the complex nature of the Nigerian society, the anti-colonial forces that emerged as a result of the war i.e. the second World Wor in Nigeria were unable to combine and seize the initiative of the colonial administration, as they had done in Ghana". 5)

This was a far cry from the positive attitudes implicit in the works of O. Ikime, E.A. Ayandele and J.F.A. Ajayi. Again one wonders why Olusanya's attitude was more negative. Was it the result of the fact that his study ended in 1953, indeed a low-point in the development of the nationalist movement? Or was it the result of the fact that olusanya wrote the book at a low-point in the country's post-independence development? Not at the moment of euphoria and joy about the achievement 
of independence and victory over the colonial enemy, but in the aftermatio of the Civil War. It was to this negative experience that olusanya referred and the end of his book:

"Unfortunately, the inability to transcend ethrido loyalties in politics has continued in the post-independence period. This factor, combined with corruption, selfishness, lack of idealism and the absence of a sound, dynamic and aisciplined leadership, was responsible for plunging the country into civil war".5)

There was only one phase of the Nigerian nationalist movement of which Olusanya approved, namely the short-lived period of radicalism (1948-50), in particular the zikist Movement, called after Dr. Nnamdi Azikiwe, who was to become Nigexia's first president:

"The period when they were in existence was an exciting one in the political history of Nigeria. It is a period Nigerians can look back on and be proud of. The zikists demonstrated the roble ideal of self-sacrifice in the nation's cause. They were thereby the only true nationalist Nigeria has ever produced". 7)

If there was any continuity in Nigerian history in the eyes of Olusanya, it was not "Nigerian" nationalism, anti-European resistance, political acumen or organizational talent etc. -- as the earlier professional historians had it -- but the inability to transcend ethnic loyalties in politics. 
Notes to Chapter Eight:

1. I have not been able to get hold of this book.

2. A.B. Aderibigbe (1973).

3. G.O. Olusanya (1973), p. 113.

4. In this respect it would have been interesting to compare the book with the original thesis.

5. G.O. Olusanya (1973), p. 75.

6. idem, p. 163.

7. G.O. Olusanya (1966), p. 133. 


\section{Conclusions}

This historiographical essay does not claim to be complete. Nevertheless it is possible to arrive at some general conclusions as to what have been the most significant features of wigerian historiography during the period under study, and as to what developincits ard shifts in focus have taken place.

In this section we will also try to link up again with African historiography written by both Africans and western scholars, and return to the more general framework with which we began.

A conclusion which forces itself upon the reader of this essay (as well as upon the student of Nigerian historiography) is that nost Nigerian historical studies are studies in political history. This is true for the studies dealing with the Scramble Era and with the impact of European presence and conquest upon African political systems. It is also true for colonial history written by Nigerians, the bulk of which was made up-- as we have seen-by "new administrative." history", which evaluated the impact of British administration upon the traditional political organisation of the various subject peoples. Even the few contributions to contemporary history by Nigerians (i.c. those by Olusanya) centred upon the political movements and parties leading to (political) independence.

This preoccupation with political history was closely related to the overemphasis on certain social (elite) groups and the relative neglect of the ordinary people. These aspects have been argued convincingly throughout this essay-- I believe-- and need not detain us here. Apparently these imbalances are not typical of Nigerian historiography only: Thomas Hodgkin-- himself one of the Western pioneexs of African History-- admitted that the Africanist historians of the late fifties and early sixties were excessively concerned with what he called for the sake of brevity "state-centred history". 1) 
Looking back to "where the paths began" he even gave some reasons for this one-sided concentration upon the political history of the elite:

"... the nature of the evidence--chronicles, correspondence, praise-documents generally tend to mirror the lives of the ruling families; concern to establish a working chronology (dynasties have more and better dates than "the short and simple annals of the poor"); desire to explode the colonial stereotype, with its confused, and confusing, categories of the 'tribal', 'primitive', 'stagnant' and the like." 2) Christopher Wrigley's criticism of early African historiography written by African and European scholars was even more ruthless.

"...just as the political scientists have conditioned us to believe that "nation-building" is the great theme of contemporary African politics, so too the historians, during the same period, have been teaching us to see state-formation as the dominant and almost the only significant theme of earlier history. (...) African and Afrophile historians felt that they had to demonstrate that Africans were not inherently incapable of governing states". 3)

According to Wrigley this resulted in a description of the African past "in terms of the construction and expansion of governmental systems and as seeing it as moving always to its grand climacteric, the emergence of the New Independent States of the later twentieth century". 4) In Wrigley's eyes the early African historiography was not only too exclusively political history and history "written almost exclusively from the point of view of Africa's present ruling class" 5), it was also anachronistic history distorting the past in order to make it the hand-maiden of the present.

"Thus assumptions about the political present were fed into the study of history, and from there they were fed back into the present with enormously enhanced power". 6)

In the Manifestoes of African historians analysed above, we have seen that it was their stated purpose to valialte the new states intellectually by showing them to be the culmination of a long evolutionary trend. This was to be the relevance of their historical research, which was to be "action de salut public". The same preoccupation with rehabilitation, with revealing the (trans-) continuity of the Nigerian past has been shown to be characteristic of many works of Nigerian historiography. 
In their rejection of this early African historiography some European Africanists have gone as far as to say that African Studies are in a state of crisis. ${ }^{7)}$ What was meant by this? T.O. Ranger in his article entitled "Towards a Usable African Past", distinguished several aspects of this crisis: in the USA the crisis had both intellectual aspects (a loss of interest in African history in favour of general questions of methodology) and economic aspects (the falling away of job opportunities for graduates in African history; the severe cut-back in graduate research grants; the collapse of much Africanist publishing). In Britain the crisis was evident in the disappearance of the old excitement and commitment. In Africa the sense of crisis alledgedly expressed itself in a wide-spread disenchantment with African historiography as artificial and distant from real issues. ${ }^{8)}$ It is this last aspect that concerns us here. According to Ranger younger students and intellectuals within Africa found present African historiography useless to them:

"They see African historiography as having contributed exclusively to cultural nationalism. The African past has been important as a source of pride and sometimes as a legitimising charter for the present regimes. But, the young radicals object, the poor and hungry cannot eat past cultural achievements, and in any case contemporary regimes merely manipulate a version of the past and in practice often display a commitment to modernist transformation which disregards African realities". 9)

Reasons for their disenchantment were according to Ranger a.o. the largely political emphasis of most African historical writing and the neglect of economic or agricuitural, and conceptual history. He advocated a history that would be "usable" and relevant to young African radicals. This "usable" historiography should consist essentially of regional, social and economic studies which would focus upon the material way of life of the people as well as their modes of thought, 10) upon the problem of poverty; of development and decline in rural areas. ${ }^{11)}$ Ranger referrea mainly to the East African context. If we return to Nigerian historiography we must conclude that there is no sign of crisis whatsoever. Maybe C. Fyfe was correct in suggesting in his Introduction that:

\footnotetext{
"Perhaps in their readiness to diagnose crisis, Africanists, Whig or radical are (...) interpreting as a crisis in African studies their own failure to solve (as they somehow feel i.t their responsibility to solve) Africa's problems". 12)
} 
Indeed the aspects of crisis mentioned by Ranger are all absent in Nigeria: African publishing flourishes; opportunjties for graduates in African Studies appear to be still rosy, since four universities and two university colleges have been added to the six universities in existence before 1975. There is no sign of either an economic or an intellectual crisis in Nigerian historiography. Even Ranger himself admitted that the Nigerian participants of the Edinburgh conference to which he himself deliverea his paper, "... made it clear that in their view the achievements of Nigerian academic historians-- as represented by the Ibadan history series-- were still very much a source of legitimate pride and the kind of topics they had explored were still very relevant to the intellectual concerns of the Nigerian nation". 13)

One might think of several reasons for the absence of this crisis, e.g. the boom of the universities, or the economic boom of Nigeria in general. But there is another, much more important reason. Nigerian historiography-- as we have seen-- was not static; it was constantly shifting focus and revising its approaches. It is this continuous process of adaptation, of internal evolution that makes the occurence of a crisis which was to shock Nigerian historians out of their current approaches to African history unnecessary and superfluous.

E.A. Ayandele denounced five major imbalances of Nigerian historiography in 1969, as we have seen more than once in this essay. But the revision of the existing approach and emphasis was not only professed in new "Manifestoes", it manifested itself also in actual research: the overemphasis on the scramble (or late precolonial) period in the first works of professional Nigerian historiography was corrected by a range of studies dealing with Nigeria's colonial past. The overemphasis on the question of African reaction to European action was balanced by the studies of S.A. Akintoye, B. Awe, and E.J. Alagoa a.o. who examined the internal dynamics of African precolonial history and developments which did not result from outside, European impulses. The unduly large attention given to the largest ethnic groups, and to the centralised (coustal) city-states was balanced by studies of highly fragmented, "stateless" or decentralised societies, as is evidenced by E.J. N17goa and O. Ikime's 
most recent studies. 14) As for the relative neglect of Northern Nigeria, this will be remedied very soon by research which has been completed but has not been published as yet, and by Ph.D. theses still in preparation. 15)

There is an evolution in the use of oral traditions; not only do they feature more prominently among the historical sources of more recent historians than they did in the work of $\mathrm{K} . \mathrm{O}$. Dike and J.F.A. Ajayi; also a more "scientific", i.e. veriafiable way of referring to oral evidence has evolved as is evident from the work of E.J. Alagoa and J.A. Atanda. 16)

The most significant development in Nigerian historiography is, no doubt, the trend away from largely political history of the upper layers of society which was characteristic of early Nigerian historical writing, and a movement towards social and economic history of the common people.

"Political problems have largely dominated historical discussions of the Yoruba country in the nineteenth century and have tended to obscure a consideration of other interesting developments which took place during that period", said Bolanle Awe at the beginning of her article "Militarism and Economic Development in Nineteenth Century Yoruba country: the Ibadan Example". 17) The paper itself dealt with the social and economic consequences of the political and military crisis which characterised the first half of the nineteenth century .

A.E. Afigbo apparently left the field of new administrative history for economic history, for his article on "Trade and Trade Routes in Nineteenth Century Nsukka" 18) was conceived "as a contribution to this area of micro-studies of trade and trade routes in Southeastern Nigeria, based mainly on oral traditions, since it concerns an area neglected by both colonial and nationalist governments".

In his contribution to the Edinburgh Seminar of 8 November 1974 the economic historian A.G. Hopkins did not speak about African historiography in terms of "crisis" as his colleague T.O. Ranger did. Hopkins referred to the changes which had taken place in African historiography in terms of a change of heart, in terms of a loss of optimism which he located somewhere in the late 1960s. About early 
African historiography of the first years after independence Hopkins said:

"This was the moment of optimism, when economists seemed capable of planning prosperity for the underdeveloped world, when sociologists and social psychologists felt certain they could convert Weberian Traditional Man into a Marshallian maximiser, and when systems analysis seemed to have reached the point where political scientists knew what inputs throughputs and outputs were needed to maintain stability in a decolonised world. History, too, partly by accident, partly by design, had a role to play in legitimating the new nation states. Hence the stress laid on the creativity of African cultures, the prominence given to famous African leaders, and the emphasis placed on the importance and, by sleight of mind, the desirability of large unitary states". 20)

Why did this loss of optimism occur? It occurred in the face of the enduring and in some cases deepening problems of the Third World. "The problem-solvers" active at the moment of optimism mentioned above "have lost some of their funds, much of their status and virtually all their élan",

"... since western capitalism has so far failed to solve the problems of the Third World and is itself experiencing a profound crisis, it is not surprising that the main drive behind the current revival of history (compare this to T.O. Ranger's concept of crisis!) comes from a radical pessimism which draws its inspiration, though not always its teaching, from Marx.

"Relevance" is still the test of the new historic vérite as it was in the early 1960s, but now the purpose of history is to locate the roots of underdevelopment rather than to legitimate post-colonial states. Today, economists, political sociologists and political historians are turning to economic history for an explanation of the present and for a guide to the future". 22)

Is this loss of optimism also perceptible in Nigerian historiography?

A ioss of optimism did occur, I believe, but it appears to have been caused not so much by a confrontation with the reality of poverty and underdevelopment, as by a confrontation with the reality of national disunity and tribalism in the Civil war.

The absence of a crisis in Nigerian historiography does not signify that it stagraced in the early phase in which it was designed to legitimize and to inspire the new state, and in which it tended to depict all earlier history as leading up to the present political status quo. The shift in focus from the Scramble Era to the colonial period in itself implied a rejection of the principle of (trans-) 
continuity between the pre- and postcolonial period and an attempt to come to terms with the colonial legacy. Even if most of the "new administrative historians" did not define the relevance of their study in terms of contributions to the solution of current problems which beset the Nigerian state; and even if most of them did not take their subjects as far as 1960, they were in any case no longer concerned with legitimizing present success. At times the historians have shown themselves critical of the politicians running the state and sceptical towards the military government in power since 1966, for even if the commitment to a strong and unified nation was still present, the blind optimism and faith in the political leaders and the actual course of events was gone. This pessimism was most evident in G.O. Olusanya's negative evaluation of the Nigerian nationalist movement, and his belief in the continuity of Nigeria's inability to overcome ethnic divisions. Obaro Ikime actually set out to reveal the colonial roots of present problems and failure: inter-tribal tensions. His study was an excellent illustration of the evolution of Nigerian historiography from history serving present success to a history concerned with present failure. As for the trend away from political history towards social and economic history, as yet there is no sign of a preoccupation with problems of poverty and underdevelopment, nor from any "radicalism" on the part of the historian, to which T.O. Ranger and A.G. Hopkins referred in statements quoted above.

In contrast to A.G. Hopkins I will not hazard a preaiction of future directions and developments of Nigerian historiography on the basis of reading a selection of academic palms, gauging the atmosphere at some current conferences and shuffling the bibliographical cards of recent publications. 24) Holland would be hardly the right place to attempt such an undertaking. Yet, I hope to have pointed out correctly the new trends in Nigerian historiography. Also I hope to have made plausible my suggestion that Nigerian historians-- constantly reinforced by new levies of Ph.D. students-are flexible enough not to need a "crisis" to be shocked out of their current approaches to African history. 
Notes to Chapter Nine:

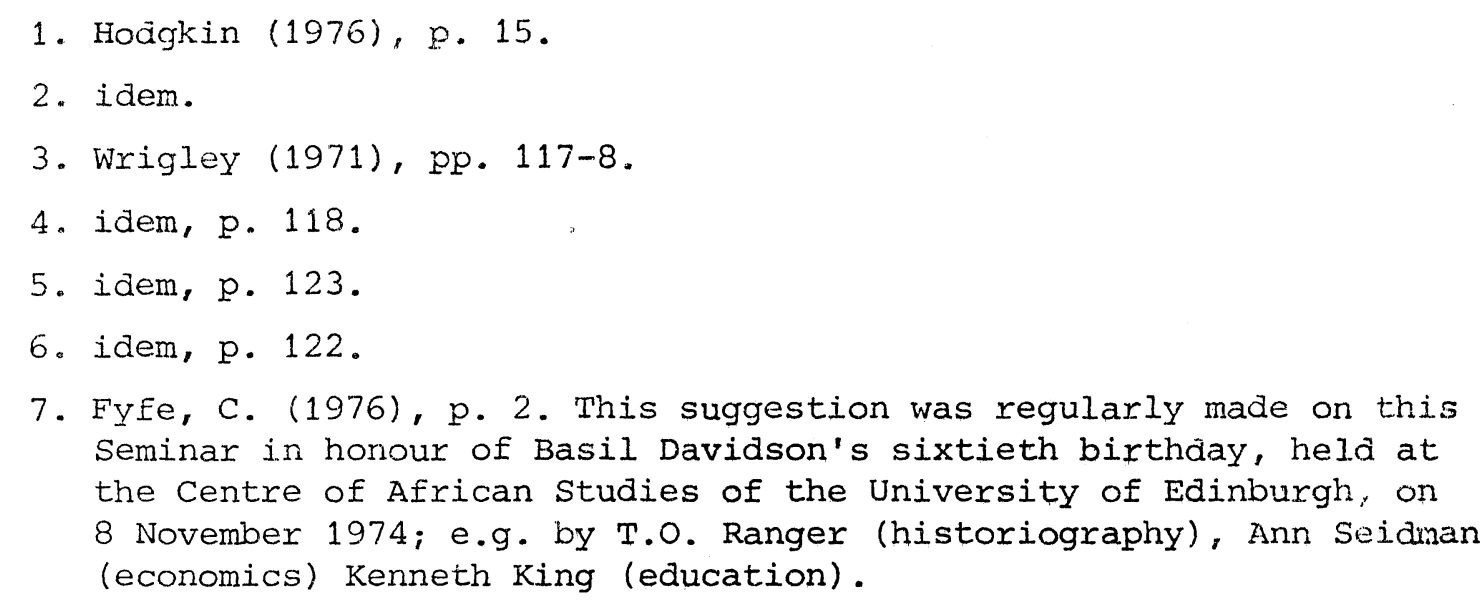

8. Ranger (1976), p. 17

9. idem, p. 21 .

10. idem, p. 26 .

11. idem, p. 25 .

12. Fyfe, C. (1976), p. 4.

13. Ranger (1976), p. 17.

14. E.J. Alagoa (1972) and (1969); O. Ikime (1973) and (1974).

15. A.B. Aderibigbe (1973).

16. J.A. Atanda (1973), p. $309 f f$.

17. B, Awe (1973), p. 65.

18. A.E. Afigbo (1973).

19. idem, p. 78 .

20. Hopkins (1976), pp. 31-32.

21. idem, p. 32 .

22. idem. He referred to Samir Amin, W. Rodney, I. Wallerstein, R.A. Austen, E.A. Alpers, the French economic anthropologists M. Godelier, E. Terray and Cl. Meillassoux, and John Iliffe. T.O. Ranger referred to six Tanzanian M.A. students and W. Ochieny. Compare G.C.Mutiso (1973), p. 153: The second generation academics generally "matured intellectually in the mid- and later 1960s, when the euphoria of Independence was wearing off. They are basically cynics, as reflected in the literary writings of the mid-1960s. They are the children of despair. They recognize that juridical independence led to neo-colonialism and the indirect control of critical institutions of the society". Mutiso did not refer to them as "radicals", however.

23. O. Ikime (1970), p. 308; and (1969), p. 272.

24. A.G. Hopkins (1976), p. 31. 
Bi.bliography

Achebe, Chinua (1970) - "The Duty and Involvement of the African Writer".

in: Cartey \& Kilson (1970), pp. 162-69.

Adama, H.R. (1973) - Review of Olusanya, G.O. (1973),

in: JHSN VII, 1, Dec. 1973, pp. 174-5.

Adeleye, R.A. (1968) - "The Dilemma of the WazIr: The place of the Risãlat al- Wazir 'ila ahl al-'ilm wa 'ltadabbur in the History of the Sokoto Caliphate".

in: JHSN, IV, 2, June 1968, pp. 285-312.

Adeleye, R.A. (1970) - "Rabih b. Fadlallah 1879 - 1893: Exploits and impact of political relations in Central Sudan".

in: JHSN, V, 2, June 1970, pp. 223-242.

Adeleye, R.A. (1970a) - RabIh b. Fadlallah and the Diplomacy of European Imperial Invasion in the Central Sudan: 1893-1902".

in: JHSN, V, 3, Dec. 1970, pp. 399-418.

Adeleye, R.A. (1971) - Power and Diplomacy in Northern Nigeria 1804-1900 - the Sokoto Caliphate and its Enemies. Ibadan History Series, London, 1971.

Adeleye, R.A. (1972) - "Mahdist Triumph and British Revenge in Northern Nigeria: Satiru 1906".

in: JHSN, VI, 2, June 1972, pp. 193-214.

Adeleye, R.A. \& I.A. Mukoshy (1966) - "Sifofin Shehu, an autobiography and character study of "uthmàn b. Füdi in verse".

in: Research Bulletin, II, 1, Jan. 1966, pp. 23-36

Aderibigbe, A.B. (1959) - "Expansion of the Lagos Protectorate 1963 - 1900".

Submitted for the Ph.D. degree at the Univ. of London, July 1959.

Unpublished.

Aderibigbe, A.B. (1962) - "Trade and Expansion in the Lagos Area in the 19th Century"

in: The Nigerian Journal of Economic and Social Studies, IV, 2, July 1962, pp. 188-195.

Ac̄eribigbe, A.B. (1973) - "Trends and Patterns in Recent Historical Research in Nigeria", a paper presented at the Third International Congress of Africanists, Addis Ababa Ethiopia, December 9-19, 1973. Mimeographed.

Aderibigbe, A.B. ed. (1976) - Lagos: the development of an African City. 
Afigbo, A.E. (1965) - "Herbert Richmond Palmer and Indirect Rule in Eastern Nigeria 1915-1928"

in: JHSN, III, 2, Dec. 1965, pp. 295-312.

Afigbo, A.E. (1966) - "Oral Tradition and History in Eastern Nigeria (An Essay in Historical Methodology). Part 1: Collecting the Evidence. Part 2: Using the Evidence."

in: African Notes, III, 3, April 1966, pp. 12-20 and IV, 1 Oct. 1966, po. 17-27.

Afigbo, A.E. (1966a) - "Revolution and Reaction in Eastern Nigeria 1900-1929 - the Background to the Women's Riot of 1929".

in: JHSN, III, 3, Dec. 1966, pp. 539-558.

Afigbo, A.E. (1966b) - review of Ajayi, J.F.A. (1965).

in: JHSN, III, 3. Dec. 1966, pp. 575-579.

Afigbo, A.E. (1967) - "The Native Treasury Question under the Warrant Chief System in Eastern Nigeria 1899-1929".

in: Odu, IV, 1, July 1967, pp. 29-43.

Afigbo, A.E. (1967a) - "The Warrant Chief System in Eastern Nigeria: Direct of Indirect Rule?"

in: JHSN, III, 4, June 1967, pp. 683-700.

Afigbo, A.E. (1968) - "The Background to the Southern Ivigerian Education Code of 1903".

in: JHSN, IV, 2, July 1968, pp. 197-226.

Afigbo, A.E. (1970) - "Sir Ralph Moor and the Economic Development of Southern Nigeria 1896-1903".

in: JHSN, V, 3, Dec. 1970, pp. 371-398.

Afigbo, A.E. (1971) - review of Crowder \& Ikime, eds. (1970), in: Odu, new series, no. 5, April 1971, pp. 99-110.

Afigbo, A.E. (1971a) - "The Eclipse of the Aro Slaving Oligarchy of South-Eastern Nigeria 1901-1927".

in: JHSI, VI, 1, Dec. 1971, pp. 3-24.

Afigbo, A.E. (1971-2) - "The Aro of South Eastern Nigeria: A SocioHistorical Analysis of Legends of their Origin".

in: African Notes 6, 2, 1971, pp. 31-46 and African Notes 7, 1, 1972, pp. 91-106.

Afigbo, A.E. (1972) - The Warrant Chiefs; indirect rule in South Eastern Nigeria 1891-1929. I.H.S. London, 1972

Afigbo, A.E. (1972a) - "The Aro Expedition of 1901-1902. (an episode in the British occupation of Iboland)

in: Odu, new series, no. 7, April 1972, pp. 3-27.

nFigbo, A.E. (1972b) - "Trade and Politics on the Cross River, 1895-1905".

in: THSG, XIII, 1, 1972, pp. 21-49.

Afigbo, A.E. (1973) - "Trade and Trade Routes in 19th century Nsukka". in: JHSN, VII, 1, Dec. 1973, pp. 77-90. 
Afigbo, A.E. (1973a) - "Monocausality and African Historlographythe case of Efik society and international commerce". Review Article of A.J.H. LathamOld Clabar 1600 - 1891: the impact of the international economy upon a traditional society. Oxford, 1973.

in: TSHG, XIV, 1, 1973, pp. 117-28.

Afrigbo, A.E.(1973b) - "The Indigenous Political Systems of the Igbo".

in: Tarikh 4, 2,.1973 entitled "Government in Pre Colonial Africa", pp. 13-23.

Afigbo, A.E. (1973C) - "Patterns of Igbo Resistance to British Conquest". in: Tarikh, 4, 3, 1973 entitled "European Conquest and African Resistance", pp. 14-23.

Afigbo, A.E. (1974) - "Indirect Rule in Southeastern Nigeria: the era of the warrant chiefs 1891-1929".

in: Tarikh, 4, 4, 1974 entitled "European Conquest and African Resistance 2, pp. 11-24.

Africa South of the Sahara 1976/77- sixth edition of a survey and reference book of all the countries south of the Sahara Desert including a Who's who of major personalities in the region. London, 1976.

Aguessy H. (1971) - "La phase de la négritude". in: Présence Africaine, 80, 1971, pp. 33ff.

Ajayi, J.F.A. (1959) - "Henri Venn and the policy of Development". in: JHSN, I, 4, Dec. 1959, pp. 331-42.

Ajayi J.F.A. (1960) - "Samuel Lewis of Sierra Leone: the Problems of African Biography". Review Article of J.D. Hargreaves - Life of Sir Samuel Lewis. London, 1959. in: JAH, 1(1960), pp. 170-1.

Ajayi J.F.A. (1960a) -"Nigerian Nationalism". Review of Coleman, J.S. (1958).

in: Ibadan, 10, Nov. 1960, pp. 16-18.

Ajayi, J.F.A. (1960b)-"How Yoruba was reduced to writing".

in: Odu, 8, Oct. 1960, pp. 49-58.

Ajayi, J.F.A. (1961) -"Nineteenth Century Origins of Nigerian Nationalism".

in: JHSN, II, 2, Dec. 1961, pp. 196-203.

Ajayi, J.F.A. (1961a)-"The British Occupation of Lagos 1851-61:

A Critical Review".

in: Nigeria Magazine, 69, Aug. 1961, pp. 96-105.

Ajayi, J.F.A. (1962) - -Milestones in Nigerian History.

Ajayi, J.F.A. (1964) -"Samuel Johnson, Historian of the Yoruba". in: Nigeria Magazine, 81, June 1964, pp. 141-6.

Ajayi, J.F.A. (1964a)-"History for determining Age". in: African Notes, 1, 2, Jan. 1964, pp. 11-12. 


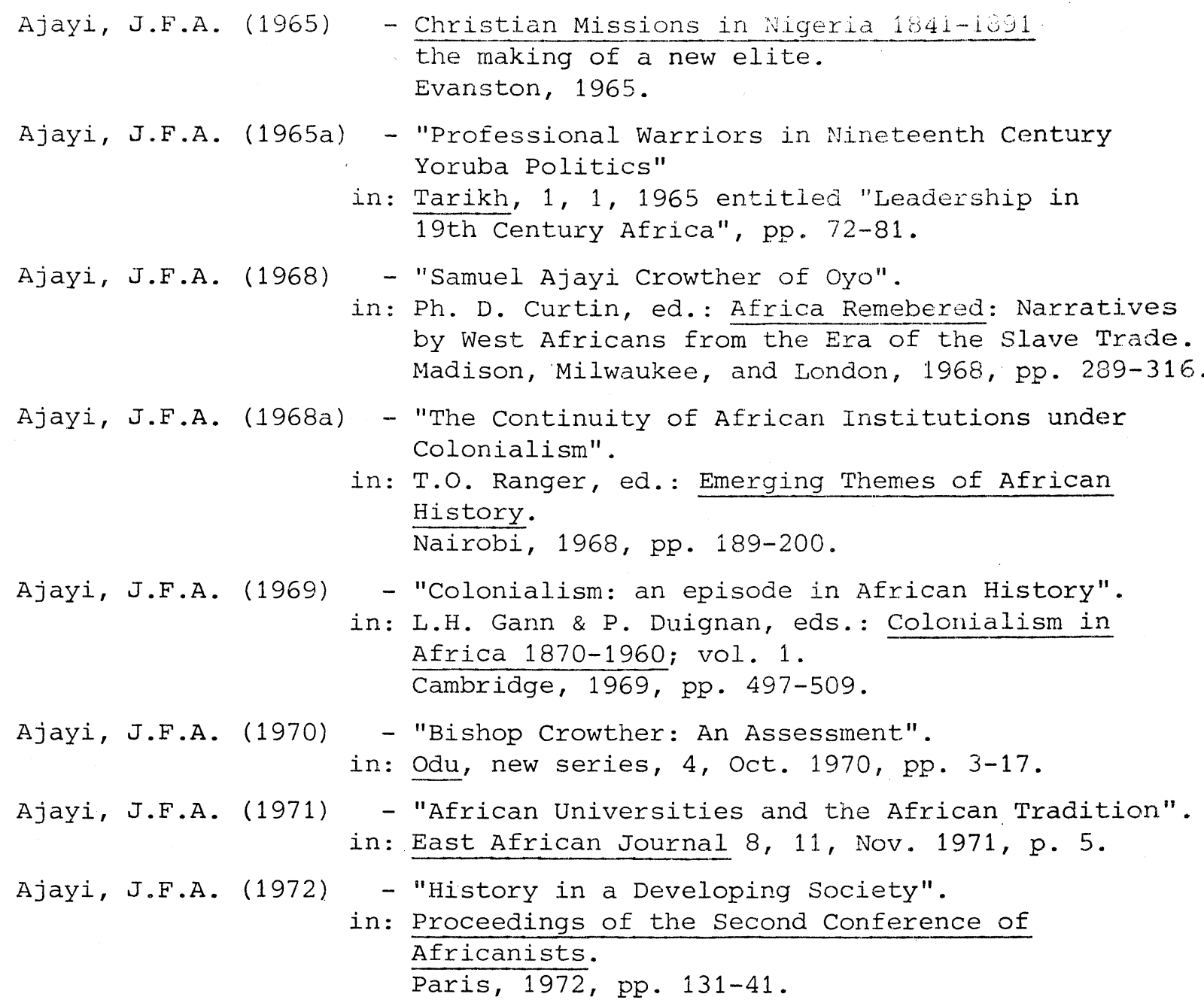

Ajayi, J.F.A. \& K. Smith (1964) - Yoruba Warfare in the 19th Century.

Ajayi, J.F.A. \& I. Espie (1965) - A thousand years of West African History. Ibadan, 1965.

Ajayi, J.F.A. \& E.J. Alagoa (1974)-"Black Africa: The Historian's Perspective".

in: Sidney w. Mintz, ed.: Slavery, Colonialism and Racism. New York, 1974, pp. 125-34. also in: Daedalus, spring 1974, pp. 125-34.

Akerejola, G.B. (1970) - The History of Ogori: (With an introduction by Eva Krapf Askari).

I.A.S. Occasional Publication no. 22. Ibadan, 1970.

Akinjogbin, I.A. (1963)- "Agaja and the Conquest of the Coastal Aja States 1724-1730".

in: JHSN, II, 4, Dec. 1963, pp. 545-66.

Akinjogbin, I.A. (1965) - "The Prelude to the Yoruba Civil Wars of the 19 th century".

in: Odu, 1, 2, 1965, pp. 24-46. 
Akinjogbin, I.A. (1966)

Akinjogbin, I.A. (1966a)

Akinjogbin, I.A. (1966b)

Akinjogbin, I.A. (1967)

Akinjogbin, I.A. (1968)

Akinjogbin, I.A. (1969)

Akintoye, S.A. (1969a)

Akintoye, S.A. (1970)

Akintoye, S.A. (1971)

Akintoye, S.A. (1971b)

Akintoye, S.A. (1975)

Akintunde, J.O. (1974)

Alagoa, E.J. (1960)

Alagoa, E.J. (1964)

Alagoa, E.J. (1966a)

Alagoa, E.J. (1966)
- "The Oyo Empire in the 18 th century- a Reassessment".

in: JHSN, III, 3, Dec. 1966, pp. 449-60.

- "Archibald Dalzel: Slave Trader and Historian of Dahomey".

in: JAH, VII, 1,1966 , pp. 67-78.

- "A Chronology of Yoruba History, 1789-1840".

in: Odu, 2, 2, Jan. 1966, pp. 81-6.

- Dahomey and its Neighbours, 1708-1818. Cambridge, 1967 .

- "The Economic Background of the Ekitiparapo, 1878-1893".

in: Odu, 4, 2, Jan. 1968, pp. 30-52.

- "The Ondo Road Eastwards of Lagos, 1870-1895".

in: JAH, $\mathrm{X}, 4,1969$, pp. 581-98.

- "The North-Eastern Yoruba Districts and the Benin Kingdom".

in: JHSN, IV, 4, June 1969, pp. 539-54.

- "Obas of the Ekiti Confederacy since the Advent of the British".

in: Crowder, M. \& O. Ikime eds., (1970), pp. 255-71.

- Revolution and Power Politics in Yorubaland, 1840-1893. Ibadan Expansion and the Rise of Ekitiparapo. Ibadan History Series London, 1971.

- "The Independence Movement in the former Belgian Congo".

in: Tarikh, 3, 4, 1971, entitled "Independence Movements in Africa", 1, pp. 51-63.

- "Nigerian Contributions to Black History".

in: Nigeria Magazine, Festival issue, no. 115-6, 1975 pp. 116-136.

- "Nigerian National Character: A Political Science Perspective".

in: Odu, 9, April 1974, pp. 95-114.

- "Preliminary Inventory of the Records of the US Diplomatic and Consular Posts in West Africa, 1856-1935".

in: JHSN, II, 1, Dec. 1960, pp. 78-104.

- The Small Brave City State- a history of NembeBrass in the Niger Delta. Ibadan/Madison, 1964.

- "Dating oral traditions".

in: African Notes, 4, 1, 1966, pp. 6-10.

- "Oral tradition among the Ijo of the Niger Delta". in: JAH, VII, 3, 1966, pp. 405-19. 
Alagoa, E.J. $(1966 / 7)$

Alagoa, E.J. (1967)

Alagoa, E.J. (1968)

Alagoa, E.J. (1969)

Alagoa, E.J. (1970)

Alagoa, E.J. (1971)

Alagoa, E.J. (1971a)

Alagoa, E.J. (1971b)

Alagoa, E.J. (1972)

Alagoa, E.J. (1975)

Alagoa, E.J. (1975)
- "Ijo Origins and Migrations".

in: Nigeria Magazine, 91, Dec. 1966, pp. 279-88, and Nigeria Magazine, 92, March, 1967, pp. 47-55.

- "Koko: Amanyabo of Nembe".

in: Tarikh, 1, 4, 1967, entitled "Modernisers in Africa", pp. 65-75.

- "Songs as Historical Data".

in: Research Review, V, 1, 1968, pp. 1-16.

- "Oproza and Early Trade on the Escravos: a note on the Interpretation of the oral Traditions of a Small Group".

in: JHSN, V, 1, 1969, pp. 151-6

- "Long distance trade and States in the Niger Delta".

in: JAH, XI, 3, 1970, pp. 319-30.

- "19th Century Revolutions in the Eastern Delta States and Calabar".

in: JHSN, V, 4, June 1971, pp. 565-73.

- "Nembe: the City Idea in the Eastern Niger Delta".

in: Cahier d'Etudes Africaines, 42, XI, 1971, 2e Cahier, pp. 327-31.

- "The Development of Institutions in the States of the Eastern Niger Delta".

in: JAH, XII, 2, 1971, pp. 269-78.

- A history of the Niger Delta: an interpretation of Ijo Oral Tradition. Ibadan 1972.

- "The Inter- disciplinary approach to African History in Nigeria".

in: Présence Africaine, 94, 2e trim., 1975, pp. 171-83.

- "Archaeological Survey".

in: Rivers Research Scheme, first interim report. Ibadan, 1975, pp. 1-20.

Alagoa, E.J. \& A. Fombo (1972) -A chronicle of Grand Bonny. Ibadan 1972 .

Albertini, Rudolf von (1966) -Dekolonisation: Die Diskussion über Verwaltung und Zukunft der Kolonien, $1919-1960$. Köln, 1966.

Albertini, R. von (1969)

-"The impact of two world wars on the decline of colonialism".

in: $\mathrm{JCH}, 4,1,1969$, pp. 17-35.

Alexandre, Pierre (1971)
-"De l'ignorance de l'Afrique et de son bon usage: notule autobiocritique".

in: Cahiers d'Etudes Africaines, XI, 3e Cahier, 1971, pp. 448-54. 
Alexandre, Pierre (ed.) (1973) - French Perspectives in African Studies. A collection of translated essays edited with an introduction by... Oxford, 1973.

Anene, J.C. (1952) - "The Establishment and Consolidation of Imperial government in Southern Nigeria (1891-1904) theory and practice in a colonial protectorate". M.A. thesis, London, 1952. Unpublished.

Anene, J.C. (1956) - "The Protectorate Government of Southern Nigeria and the Aros, 1900 - 1902".

in: JHSN, I, 1, Dec. 1956, pp. 20-26.

Anene, J.C. (1959) - "The Foundations of British Rule in "Southern Nigeria", (1885 - 1891)".

in: JHSN, 1, 4, Dec. 1959, pp. $253-62$.

Anene, J.C. (1960) - "The Boundary Arrangements for Nigeria 1884 - 1906 -an objective study in Colonial Boundary making". $\mathrm{Ph} . \mathrm{D}$. thesis, London. Unpublished.

Anene, J.C. (1961) - "The Nigeria- Southern Cameroons Boundary; (an ethno-political analysis)". in: JHNS, II, 2, Dec. 1961, pp. 186-95.

Anene, J.C. (1963) - "The Nigeria- Dahomey Boundary". in: JHSN, II, 4, Dec. 1963, pp. 479-85.

Anene, J.C. (1963a) - "Towards a National History" in: Ibadan, 16, June 1963, pp. 7-10.

Anene, J.C. (1965) - "The Eclipse of the Bagawa". iñ: JHSN, III, 2, Dec. 1965, pp. 211-20.

Anene, J.C. (1966) - Southern Nigeria in Transition, 1885 - 1906: Theory and Practice in a Colonial Protectorate. Cambridge, 1966.

Anene, J.C. (1970) - The International Boundaries of Nigeria, 1885- 1960: The Framework of an Emergent African Nation. London, 1970.

Anene, J.C. \& G.N. Brown, eds. (1966) - Africa in the 19th and 20th Centuries: a handbook for teachers and students. London, 1966.

Anjorin, A.O. (1966) - "European attempts to develop cotton cultivation in West Africa, 1850- 1910".

in: Odu, 3, 1, July 1966, pp. 3- 15.

Anjorin, A.O. (1967) - "The Background to the Amalgamation of Nigeria in 1914".

in: Odu, 3, 2, Jan. 1967, pp. 72-86.

Anjorin, A.O. (1970) - "Two Studies of the Sokoto Caliphate", a review of M. Last: The Sokoto Caliphata (1967) and H.A.S. Johnston: The Fulani Empire of Sokoto (1967) in: Odu, new series, 3, April 1970, pp. 116-27. 
Anjorin, A.O. (1971) - "Tin Mining in Northern Nigeria during the 19 th and the early part of the 20 th century". in: Odu, new series, 5, April 1971, pp. 54- 67.

Arnold, Guy - $\frac{\text { Modern Nigeria. }}{\text { London, } 1977 \text {. }}$

Ashby, E. - African University and Western Tradition

Asiwaju, A.I. (1970) - "The Alaketu of Ketu and the Onimeko of Meko: The Changing Status of two Yoruba Rulers under French and British Rule".

in: Crowder, M. \& O. Ikime, eds. (1970), pp. 134-61.

Asiwaju, A.I. (1974) - "Anti- French Resistance Movement in Ohori - Ije (Dahomey), 1895 - 1960".

in: JHSN, VII, 2, June 1974, pp. 255-70.

Asiwaju, A.I. (1974a) - "New Trends in colonial African historiography: France and Britain in Africa". A review of P. Gifford \& W.M. Roger Louis (1971).

in: JHSN, VII, 3, Dec. 1974, pp. 563- 9.

Asiwaju, A.I. (1975) - "The Colonial Education heritage and the problem of nation-building in Dahomey".

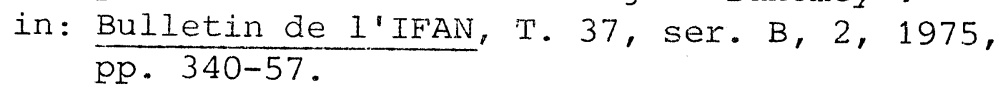

Asiwaju, A.I. (1976) - Western Yorubalana under European Rule, 1889-1945: colonialism. I.H.S.

London, 1976.

Asiwaju, A.I. (1976a) - "Political Motivation and Oral Historical Traditions in Africa: the case of the Yoruba Crowns, 1900- 1960".

in: Africa, 46, 2, 1976, pp. 113- 27.

Assorodobraj, Nina (1967) - "Le Rôle de l'Histoire dans la prise de conscience nationale en Afrique occidentale".

in: Africana Bulletin, (Warzawa), 1967, pp. 9-47.

Atanda, J.A. (1969) - "The Iseyin-Okeho Rising of 1916: An example of socio-political conflict in colonial Nigeria". in: JHSN, IV, 4, July 1969, pp. 497-514.

Atanda, J.A. (1970) - "The Changing Status of the Alafin of oyo under Colonial Rule and Indepencience".

in: M. Crowder \& O. Ikime, eds. (1970), pp. 212-30.

Atanda, J.A. (1970a) - "Indirect Rule in Yorubaland".

in: Tarikh, 3, 3, 1970, entitled "Indirect Rule in British Africa", pp. 16- 28.

Atanda, J.A. (1971) - "The Fall of the Old Oyo Empire: a Reconsideration of its cause".

in: JHSN, V, 1971, pp. 477-90.

Atanda, J.A. (1973) - The New Oyo empire; indirect rule and change in Western Ivigeria, 1894-1934. I.H.S. London, 1973. 
Atanda, J.A. (1973a) - "The Yoruba Ogboni Cult: did it exist in old Oyo". in: JHSN, VI, 4, June 1973, pp. 365- 72.

Atanda, J.A. (1973b) - "Government of Yorubaland in the Pre-Colonial Period".

in: Tarikh, 4, 2, 1973, entitled "Government in Pre-Colonial Africa", pp. 1-12.

Atanda, J.A. (1974) - "British Rule in Buganda".

in: Tarikh, 4, 4, 1974, entitled "European Conquest and African Resistance, 2", pp. 37-54.

Autra, M.T.R. (1964) - "l'Institut National de Recherches et de Documentation (1944-1964)".

in: Recherches Africaines, Jan/Dec. 1964, pp. 5-12.

Awe, B. (1964) - "The Ajele System; (a study of Ibadan Imperialism in the 19th century)".

in: JHSN, III, Dec. 1964, pp. 47-60.

Awe, B. (1965) - "The end of an Experiment: the collapse of the Ibadan Empire, 1877 - 1893".

in: JHSN, III, 2, Dec. 1965, pp. 221-30.

Awe, B. (1973) - "Militarism and Economic Development in 19th Century Yoruba country: The Ibadan Example".

in: JAH, XIV, 1, 1973, pp. 65- 77.

Awe, B. (1974) - "The Institution of the Iyalode within the Traditional Yoruba Political System".

Presented at the 17 th Annual Meeting of the African Studies Association, Chicago, Oct. 30- Nov. 2, 1974. Mimeographed.

Ayandele, E.A. (1963-4) - "An Assessment of James Johnson and his place in Nigerian History, 1874 - 1917".

Part I, 1874 - 1890 Part II, 1890 - 1917;

in: JHSN, II, 4, Dec. 1963, pp. 486-516.

\& ibid. III, 1, Dec. 1964, pp. 73-101.

Ayandele, E.A. (1965) - "Abdel Kader and the French Occupation of Algeria, 1830 - 1847".

in: Tarikh, 1, 1, 1965, entitled "Leadership in the 19th Century Africa", pp. 53-63.

Ayandele, E.A. (1966) - The Missionary Impact on Modern Nigeria. 1842 - 1914: A Political and Social Analysis. I.H.S. London, 1966.

Ayandele, E.A. (1966a) - "The Missionary Factor in Northern Nigeria, 1870 - 1918".

in: JHSN, III, 3, Dec. 1966, pp. 503-22.

Ayandele, E.A. (1966b) - "Moulay Abdel Aziz, Herald of French Conquest of the Sherifian Empire".

in: Tarikh, 1, 2, 1966, entitled "African Leadership and European Domination", pp. 26-38. 
Ayandele, E.A. (1967) - "Background to the "Duel" between Crowther and Goldie on the Lower Niger, 1857 - 1885".

in: JHSN, IV, 1, Dec. 1967, pp. 45-64.

Ayandele, E.A. (1967a) - "The Mode of British Expansion in Yorubaland in the second half of the 19th century: The Oyo Episode".

in: Odu, 3, 2, Jan. 1967, pp. 22-43.

Ayandele, E.A. (1967b) - "Observations on Some Social and Economic Aspects of Slavery in Pre-Colonial Northern Nigeria".

in: $\frac{\text { The Nigerian Journal of Economic and Social }}{\text { Studies, } 9,3, \text { Nov } 1967, \text { po } 329-38}$

Ayandele, E.A. (1968) - "The relations between the Church Missionary Society and the Royal Niger Company".

in: JHSN, IV, 3, Dec. 1968, pp. 397-420.

Ayandele, E.A. (1968a) - "The Colonial Church Question in Lagos Politics, 1905-1911".

in: Odu, IV, 2, Jan. 1968, pp. 53-73.

Ayandele, E.A. (1969) - "How truly Nigerian is our Nigerian History". in: African Notes, 5, 2, Jan. 1969, pp. 19-35.

Ayandele, E.A. (1969a) - "Traditional Rulers and Missionaries in Pre- Colonial West Africa".

in: Tarikh, 3, 1, 1969, entitled "Christịanity in Modern Africa", pp. 23-37.

Ayandele, E.A. (1970) - Holy Johnson: Pioneer of African Nationalism $1836-1917$.

London, 1970 .

Ayandele, E.A. (1970a) - "The Changing Position of the Awujales of Ijebuland under Colonial Rule".

in: M. Crowder \& O. Ikime, eds. (1970), pp. 231-54.

Ayandele, E.A. (1970b) - "The Ideological Ferment in Ijebuland, 1892-1943"

in: African Notes, 5, 3, Jan. 1970, pp. 17-40.

Ayandele, E.A. (1970c?) - Chieftancy in Ijebuland 1892 - 1948: the interpretation of religion and politics".

in: University of East Africa Social Sciences Council Conference 1968/69; VII volumes. Vol. III: History Papers. Makerere Institute of Social Research.

Kampala, n.d., pp. 13-33.

Ayandele, E.A. (1971) - A Visionary of the African Church: Mojola Agbebi (1860-1917).

Nairobi, 1971.

Ayandele, E.A. (1973) - "The Collapse of 'Pagandom' in Igboland". a review article of F.K. Ekechi, (1972). in: JHSN, VII, 1, DeC. 1973, pp. 125-40. 
Backzo, Bronislaw (1969) - "La responsabilité morale de l'historien" in: Diogène, 67, (1969), pp. 61ff.

Balandier, George (1963) - "Sociologie dynamique et histoire à partir de faits africains".

in: Cahiers Internationaux de Sociologie, 34, nouvelle série, dixième année, janvier/ juin 1963, pp. 3-12.

Balogun, S.A. (1973) - "Succession Tradition in Gwandu History, 1817-1918".

in: JHSN, VII, 1, Dec. 1973, pp. 17-34.

Biobaku, S.O. (1955) - "Myths and Oral History".

in: Odu, 1, Jan. 1955, pp. 12-17.

Biobaku, S.O. (1956) - "The problem of traditional history with special reference to Yoruba Traditions".

in: JHSN, I, Dec. 1956, pp. 43-7.

Biobaku, S.O. (1957) - The Egba and their Neighbours, 1842-1872.

Biobaku, S.O. (1958) - "An Historical Sketch of the Peoples of Western Nigeria".

in: Odu, VI, 1958, pp. 24ff.

Biobaku, S.O. (1959) - "Les responsabilités de l'historien africain en ce qui concerne l'histoire et l'Afrique".

in: Présence Africaine, 27-28, Aug/Nov 1959, pp. 96-99.

Biobaku, S.o. (ed.) (1973) - $\frac{\text { Sources of Yoruba History. }}{\text { Oxford, 1973. }}$

Biobaku, S.O. (ed.) (1976) - The Living culture of Nigeria Lagos, 1976.

Bown, Lalage \& M. Crowder, eds. (1964) - The Proceedings of the First International Congress of Africanists; Accra. London, 1964.

Brunschwig, H. (1962) - "Pour une histoire d'Afrique Noire". in: Cahiers d'Etudes Africaines, II, 3e Cahier, 1962, pp. 337-8.

Brunschwig, H. (1962a) - 'l'Afrique Atlantique". in: Revue Historique, CCXXVII, 1962, pp. 197-226.

Brunschwig, H. (1963) - "Sur les travaux historiques en cours".

in: Cahiers d'Etudes Africaines, 13, IV, ler Cahier, 1963, pp. 157-8.

Brunschwig, H. (1963a) - l'Avènement de l'Afrique noire du 19e siècle $\frac{\bar{a} \text { nos jours. }}{\text { Paris, } 1963 \text {. }}$

Brunschwig, H. (1976) - "Histoire de l'Afrique noire, (1970-1975)". in: Revue Historique, CCLVI, 1, 519, July/Sept. 1976, pp. $171-205$. 
Buijtenhuijs, R. (1975) - "Quelques maladies infantiles de 1.' anthropologie révclutionnaire française". in: Cahiers d'Etudes Africalnes, 59, XV, 3, 1975, pp. 541-6.

Carr-Saunders, A.M. (1961) - New Universities Overseas.

Cartey, Wilfred \& Martin Kilson (eds.)(1970) - The Africa Reader: Independent Africa. New York, 1970.

Césaire, Aimé (1959) - "The Responsibility of the Artist"

in: Présence Africaine, Feb/March 1959, pp. $153 \mathrm{ff}$.

\& in: Cartey \& Kilson (eds.), 1970, pp. 153 ff.

Coleman, J.S. (1958) - Nigeria: Background to Nationalism. Berkeley \& Los Angeles, 1958.

Coleman, J.S. ed. (1965) - Education and Political Development

Copans, Jean (1971) - "Pour une histoire et une sociologie des études africaines".

in: Cahiers d'Etudes Africaines, 43, XI, 3, 1971, pp. $422-47$.

Coquery - Vidrovitch, C. (1976) - "Changes in African Historical Studies in France".

in: Fyfe, ed., 1976, pp. 200-208.

Cornevin, R. (1960) - Histoire des peuples de l'Afrique Noire. Paris, 1960.

Cornevin, R. (1963) - "Publications sur l'Ancienne Afrique française au sud du Sahara".

in: African Studies Bulletin, VI, 3, Oct. 1963, $\mathrm{pp}$.

Cornevin, R. (1968) - "The Problems and Character of African History (i.e. precolonial history)".

in: T.O. Ranger, ed., 1968, pp. 74-96.

Cornevin, R. (1970) - "Frankophoner Literatur in Afrika".

in: Sonderbeilage zux Zeitschrift "Afrika Heute"

1 Nov. 1970, pp. 1ff.

Crowder, M. (1964) - "Colonial rule in west Africa - factor for division or unity".

in: Civilisations, 14, 3, 1964, pp. 167-78.

Crowder, M. (1964a) - "Indirect Rule- French and British Style". in: Africa, XXXIV, 3, July 1964, pp. 197-205.

Crowder, M. (1970) - West Africa under Colonial Rule. London, 1970 (1968 ${ }^{1}$ ).

Crowder, M. ed. (1971) - West African Resistance: The Military Response to Colonial Occupation.

London, 1971.

Crowder, M. $\left(1973,1962^{1}\right)$ - The Story of Nigeria. London 1973 (1962), third revised edition. 
Crowder, M. \& O. Ikime eds. (1970) - West African Chiefs; their changing status under colonial rule and independence. New York, etc., 1970.

Curtin, Ph.D. (1960) - "Scientific" Racism and the British Theory of Empire". in: JHSN, II, 1, Dec. 1960, pp. 40-51.

Curtin, Ph.D. (1964) - The Image of Africa - British Ideas and Action, 1780-1850, London, 1964.

Curtin, Ph.D. (1974) - $\frac{\text { Precolonial African History. }}{501 \text { AHA Pamphlets, Washington, } 1974 \text { revised }}$ edition (1964).

Davies, H.J. (1967) - "Heavy-Handed and Scowling Theologies". A review of Ayandele (1966).

in: Odu, 4, 1, July 1967, pp. 73-7.

Denoon, Donald \& Ađam Kuper (1970) - "Nationalist Historians in search of a nation: the "new historiography" in Dar es Salaam."

in: African Affairs, 69, 227, Oct. 1970, pp. 329-349.

Deschamps, Hubert (1962) - "Pour une histoire de l'Afrique".

in: Diogène, 37, janvier/mars 1962, pp. 113-120.

Deschamps, Hubert (1963) - "Et maintenant, Lord Lugard?"

in: Africa, XXXIII, 4, Oct. 1963, pp. $294 \mathrm{ff}$.

Dike, K.O. (1953) - "African History and Self-Government".

in: West Africa (London), XXXVII, Feb/March 1953, pp. 177-78 \& 225-26.

Dike, K.O. (1956) - Trade and Politics in the Niger Delta, 1830-1885:

history of Nigeria.

Oxford, 1956.

Dike, K.O. (1956a) - A Century of British Rule in Nigeria, 1851-1951. Ibadan, 1956,

Dike, K.O. (1959) - "Benin, great forest kingdom of Medieval Nigeria". in: Unesco Courier, 12th Year, 11, pp. 12-4.

Dike, K.O. (1964) - "The Importance of African Studies".

in: Bown, L. \& M. Crowder, eds. (1964), pp. 19-29.

Dike, K.O. (1964a) - "The Study of African History".

in: Bown, L. \& M. Crowder, eds. (1964), pp. 55-71.

Dike, K.O. (1973) - "The Study of African History: the present position". Paper presented at Third International Congress of Africanists, Addis Ababa, Ethiopia; Dec. 9-19, 1973. Mimeographed.

Diop, Alioune (1964) - "The Spirit of "Présence Africaine".

in: Bown, L. \& M. Crowder, eds. (1964), pp. 46-51.

Directory prepared by the Secretariat of UNESCO- Social Scientists

specializing in African studies. Paris/La Haye, 1963. 
Dorward, David Craid (1973) - review of T.A. Tamuno (1970).

in: JAH, XIV, 1, 1973, pp. 173-4.

Dougala, B. (1972) - "Des ancêtres fondateurs aux présiderts modernes: continuité historique: A propos du livre de Basil Davidson; introduction à l'histoire d'une culture".

in: Présence Africaine, 83, 3e trim. 1972, pp. 123-9.

Ejimofor, Cornelius O. (1973) - "British Colonial Policies in Nigeria: The Roots of Post-independence conflicts."

Paper presented at the 16th Annual Meeting of the African Studies Ass., Syracuse, Oct. 31-Nov. 3, 1973. Mimeographed. Ekechi, F.K. (1972) - Missionary Enterprise and Rivalry in Igboland, London, 1972.

Ekundare, R.O. (1973) - An Economic History of Nigeria, 1860-1960.

Emerson, R. (1960) - From Empire to Nation- the Rise to Self-Assertion of Asian and African Peoples. Boston, 1960.

Eminent Nigerians of the Nineteenth Century, a Series of Studies originally broadcast by the Nigerian Broadcasting Company.

Cambridge, 1960.

Ensedebe, P.O. (1970) - "Origins and Meaning of Pan- Africanism". in: Présence Africaine, nouvelle série bilingue, no. 73, 1er trimestre 1970, pp. 109-29.

Esedebe, P.O. (1972) - review of E.A. Ayandele (1970). in: JAH, XIII, 1, 1972, pp. 165-8.

Etudes Africaines- liste mondiale des périodiques spécialisés. Paris/La Haye, 1969.

Fajana, A. (1966) - "Some Aspects of Yoruba Traditional Education".

in: Odu, 3, 1, July 1966, pp. 16-28.

Fajana, A. (1972) - "Colonial Control and Education: The Development of Higher Education in Nigeria, 1900-1950".

in: JHSN, VI, 3, Dec. 1972.

Fajana, A. (1972a) - "Dr. Henry Carr's Philosophy of Education- An Assessment".

in: Odu, new series, 7, April 1972, pp. 28-48.

Fafunwa, A. Babs (1971) - $\frac{\text { s History of Nigerian Higher Education. }}{\text { Lagos/Ibadan, } 1971 .}$

Finnegan, Ruth (1970) - "A note on oral tradition and historical evidence".

in: History and Theory, IX, 1970, pp. 195-201.

Fisher, H.J. (1972) - a review of R.A. Adeleye (1971).

in: JAH, XIII, 2, 1972, pp. 332-5. 
Flaig, H. (1974) - "The Historian as a Pedagogue of the Nation. in: History, 59, 1974, pp. 18-32.

Flint, J.E. (1966) - a review of J.C. Anene (1966)

in: JAH, VII, 3, 1966, p. 527.

Flint, J.E. (1965) - a review of E.J. Alagoa (1964). in: JAH, VI, 2, 1965, p. 248.

Folayan, Kola (1967) - "Egbado to 1832: The Birth of a Dilemma". in: JHSN, IV, 1, Dec. 1967, pp. 15-34.

Folayan, Kola (1969) - "The career of Thomas Tickel in the western District of Lagos, 1854-1886".

in: JHSN, $V, 1$, Dec. 1969, pp. 27-46.

Folayan, Kola (1972) - "International Politics in a Frontier zone: Egbado 1833-63".

in: odu, new series, 8, oct. 1972, pp. 3-32.

Folayan, Kola (1974) - "Dahomey before the French Conquest". in: Tarikh, 5, 1, 1974, entitled "Peoples and Kingdoms of West Africa in the Pre-Colonial Period", pp. 17-30.

Fyfe, Christopher ed. (1976) - African Studies since 1945 - a tribute to Basil Davidson. London, 1976.

Gabel, C. \& N.R. Bennett eds. (1967) - Reconstructing African Culture History. Boston, 1967.

Gann, L.P. \& P. Duignan (1967) - $\frac{\text { Burden of Empire. }}{\text { New York, 1967, }}$

Geiss, I. (1967) - "The Development of Pan Africanism". in: JHSN, III, 4, June 1967, pp. 719-40.

Geiss, I. (1976) - "The Study of African History in Germany". in: Fyfe, Christopher ed. (1976), pp. 209-219.

Gifford, P. (1967) - "Indirect Rule: Touchstone or Tombstone for Colonial Policy".

in: Gifford, P. \& W.M. Roger Louis, eds. (1967).

Gifford, Presser \& W.M. Roger Louis, eds. (1967) - Britain and Germany in Africa - imperial rivalry and colonial rule. New Haven and London, 1967.

Gifford, Presser \& W.M. Roger Louis, eds. (1971) - France and Britain in Africa - imperial rivalry and colonial rule. New Haven and London, 1971.

Glénisson, J. (1965) - "Introduction".

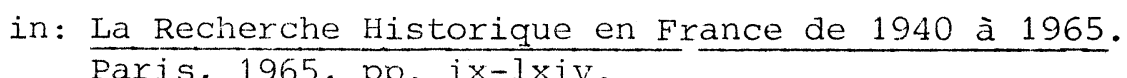

Gordon, D.C. (1971) - Self-Determination and History in the Third World. Princeton, New Jersey, 1971.

Gray, J.R. (1968) - a review of E.A. Ayandele (1966). in: JAH, IX, 1, 1968, pp. 176-7. 
Haberland, Eike (1967) - "African Studies in Germany since 1945".

in: African Notes, IV, 2, Jan. 1967, pp. 35-41.

Henige, D.P. (1971) - "Oral Traditions and Chronology".

in: JAH, XII, 3, 1971, pp. 371-89.

Henige, D.P. (1974) - The Chronology of Oral Tradition, Quest for a Chimera.

Herskovitz, M. (1964) - "The Development of Africanist Studies in Europe and America".

in: Bown L. \& M. Crowder, eds. (1964), pp. 29-45.

Hess, R.A. \& J.F. Ade Ajayi (1971) - "The New Historiography of west Africa".

in: African Studies Review, 14,2 , 1971, pp. 273-85.

Heussler, R. (1971) - "British Rule in Africa".

in: Gifford, P. \& W.M. Roger Louis, eds. (1971), pp. 571-90.

Hilliard, F.H. (1957) - A Short History of Education in British West Africa. London, 1957.

Historique de l'Institut Francais d'Afrique Noire" - no author.

in: Notes Africaines, 90, April 1960, pp. 33-44.

Hodgkin, Th. $1975\left(1960^{1}\right)$ - Nigerian Perspectives - an historical

anthology.

Hodgkin, Th. (1976) - "Where the Paths Began".

in: Fyfe, Christopher ed., 1976, pp. 6-16.

Hopkins, A.G. (1976) - "Clio-Antics: A Horoscope for African'Economic History".

in: Fyfe, Christopher ed., 1976, pp. 31-48.

Hunwick, J.O. (1976) - "The Study of Muslim Africa: Retrospect and Prospect".

in: Fyfe, Christopher ed., 1976, pp. 136-155.

Hijmans, Jacques-Louis (1971) - Leopold Sédar Senghor: An Intellectual Biography. Edinburgh, 1971.

Igbafe, Ph. (1967) - "The District Head System in Benin, 1914-1935".

in: Odu, 3, 2, Jan. 1967, pp. 3-21.

Igbafe, Ph. (1967a) - "British Rule in Benin 1897-1920: Direct or Indirect?"

in: JHSN, III, 4, June 1967, pp. 701-18.

Igbafe, Ph. (1968) - "The Benin viater Rate Agitation, 1937-39: an example of social conflict".

in: JHSN, IV, 3, Dec. 1968, pp. 355-374.

Igbafe, Ph. (1968a) - 'Oba Ovonramwen and the Fall of Benin".

in: Tarikh, 2, 2, 1968, entitled "African Achievement and Tragedy", pp. 69-80. 
Igbafe, Ph. (1970) - "The Changing Status of the Obas of Benin under Colonial Rule and since Independence".

in: Crowder, M. \& O. Ikime, eds., 1970, pp. 272-88.

Igbafe, Ph. (1970a) - "The Fall of Benin: A Reassessment". in: JAH, XI, 3, 1970, pp. 385-400.

Igbafe, Ph. (1970b) - "Indirect Rule in Benin". in: Tarikh, 3, 3, 1970, entitled "Indirect Rule in British Africa", pp. 29-40.

Igbafe, Ph. (1971) - "The Benin Trials of 1897 and 1899". in: Odu, new series, 5, April 1971, pp. 68-89.

Igbafe, Ph. (1971a) - "Western Ibo Society and its Resistance to British Rule: The Ekumeku Movement 1898-1911". in: JAH, XII, 3, 1971, pp. 441-459.

Igbafe, Ph. (1974) - "Benin in the Pre-Colonial Era". in: Tarikh, 5, 1, 1974, entitled "Peoples and Kingdoms of West Africa in the Pre-Colonial Period", pp. 1-16.

Ikime, Obaro (1965) - "The Lugardian System in Warri, 1917-32". in: JHSN, III, 2, Dec. 1965, pp. 313-34.

Ikime, Obaro (1966) - "The Anti-Tax Riots in Warri Province, 1927-1928". in: JHSN, III, 3, Dec. 1966, pp. 559-73.

Ikime, Obaro (1966a) - "Nana Olomu: Governor of the Benin River". in: Tarikh, 1, 2, 1966, entitled "African Leadership and European Domination", pp. 39-50.

Ikime, Obaro (1967) - "Native Administration in Kwale-Aboh, 1928-1950: A Case Study". in: JHSN, III, 4, June 1967, pp. 663-82.

Ikime, Obaro (1967a) - "The Western Ijo, 1900-1950". in: JHSN, IV, 1, Dec. 1967, pp. 65-86.

Ikime, Obaro (1968) - "Reconsidering Indirect Rule: The Nigerian Example". in: JHSN, IV, 3, Dec. 1968, pp. 421-38.

Ikime, Obaro (1968a) - Merchant Prince of the Niger Delta; the rise and fall of Nana Olomu, last governor of the Benin River. London, 1968.

Ikime, Obaro (1968b) - "Nigerian History in the Making", a review of J.C. Anene (1966).

in: JHSN, IV, 2, JuIY 1968, pp. 335-44.

Ikime, Obaro (1969) - Niger Delta Rivalry - Itsekiri - Urhobo Relations and the European Presence 1884 - 1936. London and Haxlow, 1969.

Ikime, Obaro (1970) - "The Changing Status of Chiefs among the Itsekiri". in: Crowder, M. \& O. Ikime, eds., 1970, pp. 289-311.

Ikime, Obaro (1970a) - "Sir Claude MacDonald in the Niger Coast Protectorate - A Re-Assessment". in: Odu, new series, 3, April 1970, pp. 22--44. 
Ikime, Obaro (1970b) - "The Establishment of Indirect Rule in Northern Nigeria".

in: Tarikh, 3, 3, 1970, entitled "Indirect Rule in British firica", pp. 1-15.

Ikime, Obaro (1971) - "Nigeria - Ebrohimi".

in: Crowder, M. ed., 1971, pp. 205-32.

Ikime, Obaro (1972) - Nana of the Niger Delta.

Ikime, Obaro (1972a) - The Isoko People: a historical survey. Ibadan, 1972 .

Ikime, Obaro (1972b) - "Colonial Conquest and Resistance in Southern Nigeria".

in: JHSN, VI, 3, Dec. 1972, pp. 251-70.

Ikime, Obaro (1973) - "The British Pacification of the Tiv, 1900-1908" in: JHSN, VII, 1, Dec. 1973, pp. 103-110.

Ikime, Obaro (1973) - "Colonial Conquest and African Resistance in the Niger Delta States".

i.n: Tarikh 4, 3, 1973, entitled "European Conquest and African Resistance, 1", pp. 1-13.

Ikime, Obaro (1974) - "The British in Bauchi 1901-1908: An Epiaose in the British Occupation and Control of Northern Nigeria".

in: JHSN, VII, 2, June 1974, pp. 271-90.

Ikime, Obaro eã. (1974a) - Leadership in 19th century Africa - essays from Tarikh. London, 1974.

Jones, D.H. (1967) - a review of T.N. Tamuno (1966).

in: JAH, VIII, 1967, pp. 366-7.

July, R.W. (1967) - The Origins of Modern African Thought - its development in West Africa during the 19th and 20th century. New York, 1967.

July, R.W. (1968) - "West African Historians of the 19th Century"

in: Tarikh, 2, 2, 1968, entitled "African Achievement and Tragedy", pp.12-24.

Junod, H.P. (1962) - "Influence du passé et du présent en Afrique". in: Genève Afrique, no. 1, 1962, pp. 80-98.

Kake, Ibrahima (1964) - "I'histoire, une dimension de l'unité". in: Présence Africaine, 1e trim. 1964, pp. 64-80.

Kanya-Forster, A.S. (1973) - a review of B.O. Oloruntimehin (1972). in: JAH, XIV, 3, 1973, pp. 511-2.

Kesteloot, Lilyan (1963) - "Les ecrivains noirs de langue française: naissance d'une littérature.

(Thèse présentée pour l'obtention du doctorat en philosophie romane).

Bruxelles, 1963.

Kimambo I.N. \& A.J. Temu eảs. (1969) - A History of Tanzania. 
Kiwanuka, Matia S.M. (1967) - "Some reflections on the role of oral traditions in the writing of the precolonial history of Africa-with special reference to the kingdom of Buganda".

in: Genève Afrique, VI, 1, 1967, pp. 63-74.

Kiwanuka, Matia S.M. (1970) - "Colonial Policies and Aaministration in Africa: The Myths of the Contrasts".

- in: African Historical Studies, III, 2, 1970, pp. 295-315.

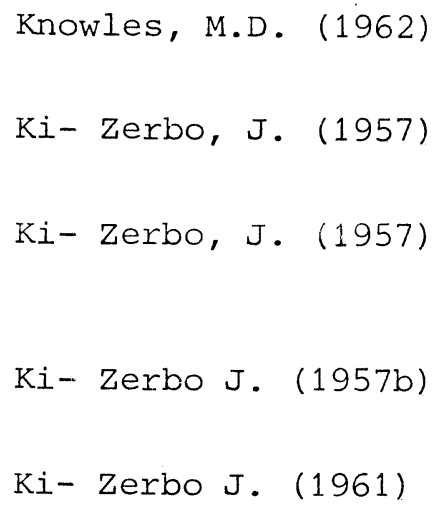

- "Academic History".

in: History, XLVII, 161, Oct. 1962, pp. 223-232.

- "Histoire et Conscience nègre".

in: Présence Africaine, n.s., 16, Oct/Nov 1957, pp. 53-69

- "L'économie de traite en Afrique noixe ou le village organisé (XVe au XXe siècle)".

in: Présence Africaine, dec/1956- jan/1957, pp. 7-31.

- "L'histoire recommence".

in: Présence Africaine, 1957, pp. 64-66.

- "Histoire: Levier fondamental: inventaire cohérent des richesses historiques africaines"

in: Présence Africaine, 37, 2e trim 1961, pp. 144-7.

- "La Tradition Orale en tant que source pour I'histoixe africaine".

in: Diogène, 67, Juil/Oct 1969, pp. 127-42.

- $\frac{\text { Histoire de l'Afrique Noire d'Hier à Demain }}{\text { Paris, 1972. }}$

- The Structure of Scientific Revolutions.

- a review of Akinjogbin (1967).

in: JHSN, IV, 2, June 1968, pp. 344-7.

- Anthropologie et Colonialisme; essai sur l'histoire de I'Africanisme. Paris, 1972 .

- Three Nigerian Emirates: A Study in oral History. Evanston, Illinois, 1972 .

- Africa in Time Perspective.

- "Les Recherches Archéologiques et Historiques en Afrique Occidentale d'Expression Francaise de. 1957 à $1961 "$.

in: Bulletin de I'IFAN, XXIV, 1-2, 1962, pp. 279-98.

- "Le Centre de Recherches Africaines de la Sorbonne". in: Bulletin de I'IFAN, XXVI, 1-2, Jan/April 1964, pp. 271-3. 
Moniot, H. (1962)

Moniot, H.(1962a)

Moore, Gerald (1970)

Morgenthau, R.S. (1967)

Muel-Dreyfus, Francine (1972)

Mushkat, Marion (1971)

Mutiso, G.C.M. (1973)

N'Diaye, Jean- Pierre

(1973)

N'Diaye, Jean-Pierre (1974)

Niane, D.T. (1974)

Nkrumah, Kwame (1964)

coenga, Th. (1975)

Obenga, Th. (1974)

Obenga. Th. (1971)

Ochiong, william (1974)

Ogunlade, F.O. (1974)
- "Pour une histoire de 1 "Afrique Noire".

in: A.E.S.C., 1, 50, 1962, po. 45-64.

- "Autour de quelques livres d'histoire aliciaine" in: Caniers d'Etudes Africaines, III, le Cahier, 1962

- "Iiterary Protest in French- speaking Africa". in: Rotberg, R.J. \& A.A. Mazruj, eds. Procest ana Power in Black Africa, 1970. pp. 807-22.

- Political Parties in Erench-speaking west Africa. London, $1967\left(1964^{1}\right)$.

- "Le Centre d'Etudes Africaines de I'EPHE - VIe Section: bilan et activitës".

in: Cahiers d'Etudes Africaines, NI, 48, 4 cahier 1972, pp. 670-708.

- "Some Characteristics of Colonialism and its product African Nationalism".

in: African studies Review, XIV, 2, sept. 1971. pp. $219-41$.

- "The Future University: towards a Multidisciplinary Research and Teaching Approach".

in: T.M. Yesufu, ed., 1973, pp. 149-158.

- "I. Kj-.. Zerbo: I'Afrique retrouvée"

in: Jeune Afrique, $658,18-4-1973$, pp. 38ff.

- "Où I'Afrique noire retrouve son antiquité". in: Jeune Afrique, 729, 28-12-1974, pp. 80-81.

- "Histoire et tradition historique du Manding". in: Présence Africaine, n.s. bilingue, 89, 1 e trim. 1974, pp. 59-74.

- "Address delivered to mark the opening of the First International Congress of Africanists".

in: Bown, Is \& M. Crowder, eds., 1964, pp. 6-15.

- "Contribution de I'Egyptologie au développement de I'histoire africaine"

in: Présence Africaine, 94, 2e trim. 1975, pp.119-139

- "Les 20 ans de "Nations Nègres et Culture", 1954$1974 "$.

in: Présence Africaine, 89, le trim. 1974, pp.214-23

- "Premier réunie plénère du Comité scientifique pour la rédaction d'une Histoire générale de I. "Afrique".

in: Présence Africaine, 78, 2e trim. 1971, pp. 262-4

- "Undercivilisation in Black Africa". in: Kenya Historical Review, 2, 1, 1974, pp. 45-58

-"Education and Politics in Colonial Nigeria the case of King 's College, Lagos (1906-1911)" in: JHSN, VII, 2, June 1974, pp. 325-46. 
Okafor, N. (1967)

Okafor, N. (1971)

Oloruntimehin, B.O. (1968)

Oloruntimehin, B.O. (1968a)

Oloruntimehin, B.O. (1969)

Oloruntimehin, B.O. (1970)

Oloruntimehin, B.O. (1970a)

Oloruntimehin, B.O. (1971)

Oloruntimehin, B.O. (1971a)

Oloruntimehin, B.O. (1971b)

Oloruntimehin, B.O. (1971C)

Oloruntimehin, B.O. (1972)

Oloruntimehin, B.O. (1972a)

Oloruntimehin, B.O. (1972b)
- The Deveiopment of Universities in Nigeria: a study of the influence of poljtical and other factors on university devehopmeit in Nigeria, 1868-1967.

London, 1967.

- "Higher Education in pre-Indépendence Nigerian Politics".

in: Nigeria Magazine, Dec. 1971, pp. 72-76.

- "Resistance Movements in the Tukolor Empire".

in: Cahiers d"Etudes Africaines, VIII, 29, le cahier 1968, pp. 123-43.

- "Muhammad Lamine in Franco-Tukulor Relations, 1885-1887".

in: JHSN, IV, 3, Dec. 1968, pp. 375-96.

- "The treaty of Niagassola, 1886: an episode in Franco- Samori relations in the era of the scramble".

in: JHSN, IV, 4, June 1969, pp. 601-13.

- "Anti-French Coalition of African States and Groups in the Western Sudan 1889-1893".

in: Odu, n.s., 3, April 1970, pp. 3-21.

- "Theories of "Official Mind" and "Military Imperialism" as related to the French Conquest of the Western Sudan".

in: JHSN, V, 3, Dec. 1970, pp. 419-39.

- "Franco- Samori Relations 1886-1889: Diplomacy as War".

in: JHSN, VI, 1, DeC. 1971, pp. 67-92.

- "Senegambia- Mahmadou Lamine"

in: M. Crowder ed. (1971), pp. 80- 110.

- "The Idea of Islamic revolution and Tukolor constitutional evolution".

in: Bulletin de I'IFAN, 33, 4, oct. 1971, pp. 675-692.

- "Constitutional Developments and the Achievement of Independence in French West Africa, 1914- 1960".

in: Tarikh 3, 4, 1971 entitled "Independence Movements in Africa, 1", pp. 33-50.

- The Segu-Tukolor Empire.I.H.S. London, 1972.

- "Theories and Realities in the Aäministration of colonial French West Africa from 1890 to the First World War"

in: JHSN, VI, 3, Dec. 1972, pp. 289- 312.

- "The Impact of the abolition movement on the social and political development of West Africa in the 19th and 20th century"

in: African Notes. VII, 1, 1972, pp. 33-58. 
Oloruntimehin, B.O. $(19 ; j)$

Oloruntimehin, B.O. (1974)

Olusanya, G.O. (1965)

Olusanya, G.O. (1966)

Olusanya, G.O. (1966a)

Olusanya, G.O. (1967)

Olusanya, G.O. (1968)

Olusanya, G.O. (1968a)

Olusanya, G.O. (1973)

Olusanya, G.o. (1973a)

olusanya, G.O. (1973b)

Ottenberg, S. (1961)

Person, y. (1962)

Povey, John (1970)

Ranger, T.O. ed. (1968)
- "French Colonialism and African Resistance in West Africa "p to the First World War".

in: Tà ikh, 4, 3, 1973 entitled "Eurcpean Conquest and African Resistance $1^{\prime \prime}$, pp. 24-34.

- "Education for Colonial Dominance in French west Africa from 1900 to the Second World war".

in: JHSN, VII, 2, June 1974, pe. 347-56.

- "India and Nigerian Nationalism".

in: Africa quarterly, $V, 3$, oct/Dec. 1965, pp. 188-91.

- "The Zikist Movement: a Study in Iolitical Radicalism, 1946-50".

in: Journal of Modern African Studies, IV, 3, 1966 , pp. 323-33.

- "The Freed Slave Homes - an unknown aspect of Northern Nigerian Social itistory".

in: JHSN, III, 3, Dec. 1966, pp. 523-38.

- "Political Awakening in the North: A Reinterpreta.tion

in: JHSN, IV, 1, Dec. 1967, pp. 125-34.

- "The Role of the Ex- Servicemen in Nigerian Politics".

in" Journal of Modern African Studies, VI, 2, 1968, pp. 221-32.

- "The Iagos Branch of the National Congress of British West Africa".

in: JHSN, IV, 2, June 1968, pp. 321-34.

- The Second World War and Politics in Nigeria, 1939-1953. Lagos, 1973 .

- "Julius Ojo-Cole: A Neglected Nigerian Nationalist and Eaucationalist".

in: JHSN, VII, 1, Dec. 1973, pp. 91-102.

- a review of T.N. Tamuno 1972.

in: IHSN, VII, 1, Dec. 1973, pp. 178--82.

- "The Present State of Ibo Studies".

in: JHSN, II, 2, Dec. 1961, pp. 211-21.

- "Traditional oxale et chronologie".

in: Cahiers d'Etudes Africaines, II, 3e cahier 1962, pp. $462-76$.

- "Political protest in the African novel in English"

in: Rotberg, R.I. \& F.A. Mazrui eds., 1970, pp.823-53 Prutest and Power in Black Africa" Oxford.

- Emerging rhemes of African History. Proceedin, if the International Congreas of African Historians held at Univ. College, Dar es Salaam, oct. 1965. Nairobi, 1968. 
Ranger, T.O. (1968a)

Ranger, T.O. (1969)

Ranger, T.O. (1976)

Ryder, A.F.C. (1960)

Senghor, L.S. (1971)

Shelton, A.J. (1964)

Simon, E. (1969)

Soyinka, Wole (1970)

Smith, Robert (1973)
- "Connexions between "primary resistance" movements and modern mass nationalism in East and Central Africa".

in: JAH, Part 1, IX, 3, 1968, pP. 437-53. Part 2, X, 4, 1968, pp. 631-41.

- "Reactions to Colonial Rule"

in: Gann, L.H. \& P. Duignan, eds. "Colonialism in Africa 1870-1960; vol. 1. Cambriage 1969, pp.293-324.

- "Towards a Usable African Past".

in: Fyfe, Christopher ed. (1976), pp. 17-30.

- "African Studies: Historians for Nigeria".

in: Ibadan, 8, March 1960, pp. 12-5.

- "Problématique de la Négritude".

in: Présence Africaine, 78, 2e trim. 1971, pp. 3-26.

- "Historiography and "New" African "History": a short exposition".

in: Genève Afrique, III, 1, 1964, pp. 81-9.

- "L'Afrique va récrire son histoire".

in: Jeune Afrique, 445, 14-7-1969, pp. 58-69.

- "The Failure of the writer in Africa".

in: Cartey \& Kilson, eds., 1970, pp. $135 \mathrm{ff}$.

- a review of S.A. Akintoye (1971).

in: JAH, XIV, 1, 1973, p. 146.

"Table Ronde sur l'Enseignement de l'Histoire en Afrique Noire".

(Paris 20-21 avril 1969)

in: Présence Africaine, 81, 1972, pp. 49-132.

Tamuno, Simeon Mark (1962).

- "The Development of British Administrative Control of Southern Nigeria, 1900-1912: a study in the administrations of Sir Ralph Moor, Sir William MacGregor and Sir Walter Egerton". Thesis submitted for the Ph.D. degree at the University of London. Unpublished.

Tamuno, Tekena Nitonye (1965) - "Some aspects of Nigerian Reaction to the imposition of British Rule".

in: JHSN, III, 2, Dec. 1965, pp. 271-94.

Tamuno, T.N. (1966)

- Nigeria and elective representation, 1923-1947. London, 1966.

Tamuno, T.N. (1967)

Tamuno, T.N. (1969)

- "Governor Clifford and Representative Government". in: JHSN, IV, 1, Dec. 1967, pp. 117-24.

- "The Role of the Legislative Council in the Administration of Lagos, 1886-1913".

in: JHSN, IV, 4, June 1969, pp. 555-570.

Note that Tamuno, Simeon Mark and Tamuno ( $T$ ) ekena (N) itonye are one and the same person. 
Tamuno, T.N. (1970)

Tamuno, T.N. (1970a)

Tamuno, T.N. (1971)

Tamuno, T.N. (1972)

- The Police in Modern Nigeria, 1861-1965; Origins, Development and Role.

Ibadan University Press, 1970.

- "Unofficial Representation on Nigeria's Executive Council, 1886-1943".

in: odu, n.s., 4, Oct. 1970, pp. 46-66.

- "The Independence Movement in Nigeria".

in: Tarikh, 4, 1, 1971 entitled "Independence Movements in Africa, 2", pp. 1-14.

- The Evolution of the Nigerian State: The Southern Phase 1898-1914. New York, 1972 .

Vansina, J.,R. Mauny \& L.V.Thomas, eds. (1964) - The Historian in Tropical Africa; studies presented and discussed at the fourth International African Seminar at the University of Dakar. Londor, Ibadan, Accra 1964.

Vansina, J. (1967)

Vansina, J. (1968)

Vansina, J. (1971)

Vansina, J. (1973)

Wallerstein, I. (1961)

Wallerstein, I. (1973)

Wautier, C. (1966)

Winks, R.W. ed. (1966)

Wise, C.G. (1956)

Wrigley, Christopher (1971)

Yesufu, 'I.M. Ga. (1973)
- "The Use of Oral Tradition in African Culture History".

in: Gabel \& Bennett, eds., (1967), pp. 57-82.

- "The Use of Ethnographic Data as sources for History"

in: Ranger, T.O. ed. (1968), pp. 97-124.

- "Once upon a time/Oral traditions as Histcry in Africa".

in: Daedalus, 100, Spring 1971 entitled "The Historian and the World of the 20th century", pp. 442-68.

- Oral Tradition: a study in historical methodology. Hammondsworth 1973 (1961 French Edition).

- "La Récherche d'une Identité Nationale en Afrique Occidentale".

in: Présence Africaine, 34-35, oct. 1960/Jan 1961, pp. 79-91.

- "Africa in a Capitalist Worla".

in: A Quarterly Journal of Africanist Opinion, III, 3 , Fal1 1973, pp. 1-11.

- The Literature and Thought of Modern Africa: A Survey.

London, 1966.

- The Historiography of the British Empire - Commonwealth trends, interpretation and resources. Durham, 1966.

- A History of Education in British West Africa London, New York, Toronto, 1956.

- "Historicism in Africa"; Slavery and State Formation.

in: African Affairs, LXx, 279, Jan. 1971, pp. 113-24.

- Creating the African Universities-merging issues of the 1970's.

Ibadan, 1973. 
Addenda

Folayan, Kola (1972a)

Folayan, Kola (1973)

Folayan, Kola (1974a)

Gbadamosi, G.O. (1972)

Monteil, Vincent (1965-66-67)
- "Tripoli and the war with the USA, 1801-1805"

in: JAH, XIII, 2, pp. 249-60.

- "The Resistance Movement in Lybia"

in: Tarikh, 4, 3, 1973 entitled "European Conquest and African Resistance, 1", pp. 46-56.

- "Italian Rule in Lybia".

in: Tarikh, 4, 4, 1974 entitled "European Conquest and African Resistance, 2", pp. 1-10.

- "The Imamate question among Yoruba Muslims". in: JHSN, VI, 2, Dec. 1972, pp. 229-237.

- "Les manuscrits historiques arabo-africains; (bilan provisoire)".

in: Bulletin de I'IFAN, v. 27, ser. B, nos. 3-4, July/Oct. 1965: pp. 531-42;

v. 28 , ser. B, nos. 3-4,

July/Oct. 1966: pp. 668-75;

v. 29 , ser. B, nos. 3-4,

July/Oct. 1967: pp. 599-603.

\section{Bibliographies}

Afrika in de xxe eeuw: Een inleidende bibliografie, samengesteld door een groep assistenten aan de afdeling Nieuwe Geschiedenis ná 1870, en afgesloten in juni 1974. Nijmegen. (Mimeographed).

Matthews, D.G. ed. (1970) - Current Themes in African Historical Studies-

a Selected Bibliographical Guide to Resources for Research in African History. African Bibliographic Center. Special Bibliographic Series. Volume, 7, number 2. Westport Connecticut, 1970.

Nduntei, O. Ita (1971) - Bibliography of Nigeria: A Survey of Anthropological and Linguistic Writings from the earliest times to 1966.

London, 1971.

Ze11, Hans M. (1975) ed. - African Books in Print. An Index by Author, Title and Subject. Part One, 1975. English Language and African languages. London, 1975. 